\title{
Improving quality of health care for gender-based violence victims at health facilities in Viet Nam
}

Mai Quoc Tung

Meiwita P. Budiharsana

Population Council

Nguyen Thi Phuong Lan

Jane H. Patten

Follow this and additional works at: https://knowledgecommons.popcouncil.org/departments_sbsr-rh

Part of the Domestic and Intimate Partner Violence Commons, and the Women's Health Commons How does access to this work benefit you? Let us know!

\section{Recommended Citation}

Mai Quoc Tung, Meiwita P. Budiharsana, Nguyen Thi Phuong Lan, and Jane H. Patten. 2010. "Improving quality of health care for gender-based violence victims at health facilities in Viet Nam," Project evaluation report. Hanoi: Population Council. 


\section{IMPROVING QUALITY OF HEALTH CARE FOR GENDER-BASED VIOLENCE VICTIMS AT HEALTH FACILITIES IN VIET NAM}

Mai Quoc Tung I Meiwita P. Budiharsana Nguyen Thi Phuong Lan I Jane H. Patten

\section{PROJECT EVALUATION REPORT}




\section{(2) Population Council}

The Population Council is an international, nonprofit, nongovernmental organization that conducts research worldwide to improve policies, programs, and products in three areas: HIV and AIDS; poverty, gender, and youth; and reproductive health.

Population Council - Viet Nam

No. 41 Le Hong Phong Street

Ba Dinh District

Ha Noi, Viet Nam

pchanoi@popcouncil.org

www.popcouncil.org

Any part of this publication may be photocopied without permission from the authors or publisher, provided that publication credit is given and that copies are distributed free. Any commercial reproduction requires prior written permission from the Population Council.

Designed \& Printed by Compass Printing.SJC.

Licence No. 293-2010/cxb/48-09/TN 


\section{PROJECT EVALUATION REPORT}

\section{IMPROVING QUALITY OF HEALTH CARE FOR GENDER-BASED VIOLENCE VICTIMS AT HEALTH FACILITIES IN VIET NAM}

Mai Quoc Tung I Meiwita P. Budiharsana Nguyen Thi Phuong Lan I Jane H. Patten

Ha Noi, October 2010 



\section{GLOSSARY}

BCC Behavioural Change Communication

CEDAW Convention on the Elimination of All Forms of Discrimination against Women

CIHP Consultation of Investment in Health Promotion

CSAGA Centre for Studies and Applied Science, Gender, Family and Adolescents

DV Domestic Violence

FF Ford Foundation

FGD Focus Group Discussion

GBV Gender-Based Violence

GSO General Statistics Office

HCMC Ho Chi Minh City

HCP Health Care Provider

HHD Ha Noi Health Department

IEC Information, Education and Communication

IDI In-Depth Interview

MOCST Ministry of Culture, Sport and Tourism

MOH Ministry of Health

MSA Medical Services Administration

NGO Non-Governmental Organization

PCVN Population Council Viet Nam

TOT Training of Trainers

UNFPA United Nations Population Fund

VAW Violence Against Women

wCCH Women's Centre for Counselling and Health Care

WHO World Health Organization 


\section{ACKNOWLEDGEMENTS}

Since 1998, many people have contributed to the Population Council studies on gender-based violence (GBV) in Viet Nam. The Population Council Viet Nam (PCVN) wishes to thank all of these real pioneers who have helped in the effort to raise public awareness about violence against women, a practice that is unacceptable and must stop. The authors regret not being able to list each person by name in this report, but would like to acknowledge their valuable contributions.

PCVN would like to acknowledge support from the Ford Foundation and an anonymous Foundation, as well as the cooperation of the following key individual researchers and representatives from partner institutions:

\section{Previous (2005) PCVN Researchers:}

Le Thi Phuong Mai

Le Ngoc Lan

Nguyen Thi Thom

Pham Le Tuan

Nguyen Thi Thanh Tam

Nguyen Van Anh

Pham Anh Tuan

\section{Representatives of Partner Institutions:}

Dr. Nguyen Thi Xuyen - Vice Minister, Ministry of Health, Head of the Project Steering Committee,

Dr. Luong Ngoc Khue - Director of Medical Services Administrations, Ministry of Health, Vice Head of the Project Steering Committee,

Nguyen Thi Thanh Ngoc, Officer of the Medical Services Administrations - Ministry of Health - Secretariat of the Project Steering Committee,

Le Anh Tuan, Associate Professor, PhD - Director of Ha Noi Health Department,

Nguyen Thi Van Anh, MD, MSc - Deputy Head of Planning Division - Ha Noi Health Department,

Pham Thi Kim Loan, MD, MSc, Officer of Planning Division - Ha Noi Health Department,

Finance and Planning Department - Ministry of Health,

Training and Scientific Department - Ministry of Health,

Legal Department - Ministry of Health,

Reproductive Health Department - Ministry of Health,

Da Nang Health Department,

Ho Chi Minh Health Department,

Da Nang Hospital, Cam Le Hospital, Nguyen Tri Phuong Hospital and Thu Duc Hospital. 


\section{TABLE OF CONTENTS}

\section{ABSTRACT:}

1. Introduction 2

2. Background of literature 3

2.1. Gender-Based Violence in a Global Perspective 3

2.2. Viet Nam and its International and National Commitments to Address GBV 4

2.3. Studies and Projects on Gender-Based Violence and Domestic Violence in Viet Nam 4

2.4. Moving Forward to Improve GBV Prevention and Care Services in Viet Nam 6

3. Pre-Intervention Assessment Study among Health Care Providers 7

3.1. Objectives and Methods 7

3.1.1. Study objectives $\quad 7$

3.1.2. Methods 7

$\begin{array}{lll}\text { 3.2. Results } & 7\end{array}$

3.2.1. Socio-Demographic Characteristics of HCPs 7

3.2.2. Knowledge and Attitudes of HCPs about GBV 9

3.2.3. Experience of Health Care Providers Working with GBV Victims 18

3.2.4. Strengthening Capacity and Enhancing Victim Support Services 27

4. Pre- and Post-Training Assessments (Training of Trainers for HCPs) 32

4.1. Objectives 33

4.2. Methods 33

4.3. Results 34

4.3.1. Characteristics of the HCPs in Da Nang and Ho Chi Minh City 34

4.3.2. Perception and Knowledge of the Health Care Providers on GBV 35

4.3.3. Roles, responsibilities and preparedness of Health Care 38 Providers in dealing with GBV victims

4.3.4. Resources at the Health Facility 43

4.3.5. Impact of Training and Feedback for Future Needs 43

5. Conclusions and Recommendations 45

5.1 Conclusions 45

5.2 Recommendations 46

$\begin{array}{ll}\text { REFERENCES } & 48\end{array}$

APPENDICES 


\section{LIST OF TABLES}

Table 3.1. Socio-demographic characteristics of HCPs (\%)

Table 3.2. HCPs' knowledge of institutions providing support for victims of violence (\%) 23

Table 3.3. HCPs' assessments of community resources for violence victims

Table 4.1. Distribution of participating HCPs by occupation

Table 4.2. Characteristics of Participating HCPs

Table 4.3. Mean score for HCP perceptions of common norms about GBV

Table 4.4. HCPs' perception about the husband's right to beat the wife

Table 4.5. HCPs' perception about a woman's right to refuse sex with her husband

Table 4.6. HCPs' opinions about the acceptability of specific behaviours

Table 4.7. Percentage of HCPs who asked about violence when there is a sign of violence in the past

Table 4.8. Perceived barriers to HCPs effectively serving GBV victims

Table 4.9. Self perception of HCPs responsibility to ask questions about violence

Table 4.10. HCP's self perception of preparedness for treating GBV victims

Table 4.11. HCPs' knowledge about selected areas of services for GBV victims

Table 4.12. HCPs' Awareness about GBV related Laws and Regulations

Table 4.13. Availability at health facility of a referral list of GBV support agencies

Table 4.14. HCPs' interest in a range of training topics, pre- and post-TOT

Table 4.15. HCPs' opinion about the training material

Table 4.16. Confidence to apply knowledge from TOT in daily work and future training 


\section{LIST OF FIGURES}

Figure 3.1. Knowledge and attitudes of HCPs about gender and GBV

Figure 3.2. HCPs identifying specific behaviours as DV or GBV (\%)

Figure 3.3. Perceived severity of domestic violence behaviours - Da Nang

Figure 3.4. Perceived severity of domestic violence behaviours - HCMC

Figure 3.5. Causes of domestic violence mentioned by participants (\%)

Figure 3.6. Consequences of domestic violence (\%)

Figure 3.7. Consequences of rape in women and girls (\%)

Figure 3.8. HCPs able to mention violent behaviours regulated by laws

Figure 3.9. How HCPs have detected victims of violence among patients (\%)

Figure 3.10. Types of domestic violence experienced by patients of HCP respondents (\% answering "Yes")

Figure 3.11. HCPs who have directly examined GBV patients, and asked patients whether wounds were caused by violence (\%)

Figure 3.12. HCPs who regularly screen patients for GBV in different situations (\%)

Figure 3.13. HCPs provision of care and support beyond medical treatment (\%)

Figure 3.14. HCPs working with other agencies to provide assistance to violence 24 victims (\%)

Figure 3.15. HCPs who know and have used GBV service provision guidelines (\%)

Figure 3.16. HCPs lacking materials to assist with services for violence victims (\%)

Figure 3.17. GBV-related training needs of HCPs (\%)

Figure 3.18. Recommendations on prevention of violence against women (\%) 



\section{ABSTRACT}

This report presents the results of the May 2009 baseline (pre-intervention) assessment among health care providers (HCPs), and the July 2010 pre- and post-Training of Trainers (TOT) assessments among HCPs, in Ho Chi Minh City (HCMC) and Da Nang, regarding the issue of quality of care for victims of gender-based violence (GBV) at health facilities in Viet Nam. As background to the presentation of the methods and findings of the two studies, there is first an overview on GBV in a global perspective and in the context of Viet Nam in particular, including brief descriptions of previous studies and projects on this issue, and the legal position of the government of Viet Nam with regards to Domestic Violence (DV). The Pre-intervention assessment included a combination of a quantitative survey among $400 \mathrm{HCPs}$ from four hospitals, in addition to four focus group discussions (FGDs), and 10 in-depth interviews (IDIs) with senior hospital personnel. Meanwhile, the later pre-/posttest study, conducted to assess the impact of TOT, simply gathered questionnaires from the 60 participating HCPs from the same two cities. The quantitative and qualitative findings of both studies provide strong evidence that the HCPs from the four hospitals have a good basic understanding of what behaviors constitute GBV, and recognize the need for support services and enforcement of the 2007 Law on DV Prevention and Control. The recognized causes of GBV included gender inequality, traditional societal norms and beliefs, poverty, low education and thus low awareness, and the effects of alcohol, among others. The consequences of violence in general and DV in particular, are considered serious not only for the victims but also the family, community and broader society. The pre-intervention study provided information about HCPs' experiences of providing services to violence victims. Depending on their position at the hospital, many participating HCPs have directly treated such patients. Due to lack of guidelines, HCPs do not regularly screen patients for DV. Although the majority of respondents reported asking patients about GBV, mostly they did so only if they had injuries clearly indicative of violence. Besides medical treatment, most HCPs at the hospitals reported providing additional support. However, clearly their skills and training were limited; they lack patient management guidelines, counselling skills, and information about referral agencies. The hospitals in the study had few or no IEC materials nor any public awarenessraising activities aimed at prevention of violence against women. HCPs also gave their views on how to prevent and manage GBV cases in the health care system and in the community. Based on their experience, HCPs suggested comprehensive measures and specific recommendations to improve GBV services and capacity of HCPs. The experiences and opinions of HCPs in each city, and of different genders, varied somewhat. The views of HCPs detailed in this report represent an important foundation for project development and implementation in the study locations. The pre- and postTraining of Trainers (TOT) questionnaire aimed to assess the HCPs on the topics covered in the training course. The results showed that basic knowledge of hospital staff about GBV improved significantly as an immediate result of training. After training all the participants were aware of the GBV Laws and related regulations. Hospital staff also acknowledged a greater sense of responsibility and readiness to work with $\mathrm{GBV}$ victims post-training. Almost all HCPs $(92 \%)$ indicated that they felt confident enough to apply what they learnt from the TOT training in their daily practice, and $72 \%$ said they would feel comfortable using the knowledge and skills obtained from the TOT to train local health staff. Finally, a selection of specific recommendations is presented, including for training of HCPs, and issues relating to facilities, tools, data, and coordination of related services. Currently, many caring HCPs in Viet Nam seek information independently to help them better serve patients who are victims of GBV. But without the support of additional training, hospital protocols, and a network of referral agencies, their efforts can only go so far. 


\section{INTRODUCTION}

In 2002, realizing the significance and importance of health care and social support for women victims of gender based violence (GBV), the Ha Noi Health Department (HHD), Population Council Viet Nam (PCVN), and the Centre for Studies and Applied Science, Gender, Family and Adolescents (CSAGA), undertook a collaborative project in $\mathrm{Ha}$ Noi entitled, "Improving health care for gender-based violence victims," supported by the Ford Foundation. This first project on integrating GBV screening into medical practice in Viet Nam was targeted at improving health care for GBV victims by training health care providers (HCPs) in two hospitals and six communes and wards. Results showed high participation of HCPs at the selected hospitals. Other accomplishments included a rapid increase of the use of the HHD's handbook for HCPs working with GBV victims, and better networking with the police, as HCPs became more aware of their legal obligation to inform the police about suspected abuse. Furthermore, the project established two Women's Centres for Counselling and Health Care (WCCH) in Duc Giang and Dong Anh hospitals. The two centres have provided support and counselling for hundreds of victims each year, serving as a valuable source of aid for GBV victims in the area (Budiharsana and Mai, 2010).

GBV issues began to be discussed much more openly during the past decade, and in 2007 the National Assembly issued the Law on Domestic Violence Prevention and Control. Yet still no national treatment guidelines existed for HCPs to use in screening, treating and referring GBV victims. To build on the HHD experience and success of the 2002 project, with support from the Ford Foundation (FF), the Ministry of Health $(\mathrm{MOH})$ in 2009 sought further technical assistance from PCVN to develop and finalize National Guidelines on Health Care for Victims of GBV, and to begin the work of up-scaling the training and implementation efforts to the national level. This project, entitled, "Improving quality of healthcare for gender-based violence victims at health facilities in Viet Nam," was also intended to further support implementation of the 2007 law, in addition to developing tools to facilitate compilation of information on GBV cases screened by health facilities nationwide.

In May 2009 an assessment study about GBV was carried out at four hospitals in Da Nang and Ho Chi Minh City ( $\mathrm{HCMC})$, interviewing more than 400 hospital staff about their perception and needs for a GBV screening training, followed by training and a period of time for application of their new knowledge and skills, including the new treatment guidelines. A final evaluation was to be conducted by June 2010 to measure the impact of the intervention (GBV training). However, by February 2010, the National Guidelines were not yet finalized and the training had not been conducted. At a coordination meeting among project partners on March 29 (initiated by PCVN), the Director General of the Medical Services Administration (MSA) of the MOH (Dr Luong Ngoc Khue) supported the appeal for finalization of the Guidelines. However the delay continued and the GBV training for 400 hospital staff members had not started by the end of June 2010 - the end of the FF grant period. After securing a no-cost extension through October 2010, and approval for a modification to the original plan, PCVN conducted a pre-/post-training assessment in July 2010, instead of a postintervention impact evaluation. Training of trainers (TOT) was held for $60 \mathrm{HCPs}$ (30 from Da Nang and 30 from HCMC), representing almost 50 different hospitals, and participants completed pre-/posttraining assessments. Consequently, this report presents results of the May 2009 baseline (pre-intervention) assessment of 400 HCPs and the July 2010 pre- and post-TOT assessments of $60 \mathrm{HCPs}$ as Trainers for future $\mathrm{MOH}$ trainings on GBV screening. 


\section{BACKGROUND OF LITERATURE}

\subsection{Gender-Based Violence in a Global Perspective}

The United Nations defines violence against women (VAW) as "any act of gender-based violence that results in or is likely to result in, physical, sexual, or psychological harm or suffering to women, including threats of such acts, coercion or arbitrary deprivations of liberty, whether occurring in public or in private life." The UN definition indicates that this encompasses physical, sexual, and emotional abuse, sexual harassment by authority figures, trafficking in women (forced labour or sex), child marriages, dowry-related violence, honour killings, and systematic sexual abuse in conflict situations (WHO, 2009).

Violence against women is a universal phenomenon, occurring in all cultures and societies. It causes serious adverse consequences to women's physical, mental, and sexual health, and all aspects of women's life, and consequently also the lives of her children. As emphasised by Heise et al. (2002) in their recent global overview of GBV, "Violence against women is the most pervasive yet least recognized human rights violation in the world. It also is a profound health problem, sapping women's energy, compromising their physical health, and eroding their self-esteem. In addition to causing injury, violence increases women's long-term risk of a number of other health problems, including chronic pain, physical disability, drug and alcohol abuse and depression." The authors also emphasize the potential effects on reproductive health, including direct risk of infection and unwanted pregnancy, and indirectly through increased sexual risk-taking.

Initial results from the WHO Multicountry Study on Women's Health and Domestic Violence against Women, which included 10 countries (including in Asia, Bangladesh and Thailand), have shown that DV is widespread. Reportedly, $15 \%$ to $71 \%$ of women reported physical or sexual violence by a husband or partner, $24 \%$ to $40 \%$ of women said that their first sexual experience was not consensual, and $4 \%$ to $12 \%$ of women reported being physically abused during pregnancy (WHO, 2009).

Women are at increased risk of violence and maltreatment throughout their lifespans. A girl can be a victim of violence even before birth if her parents choose to abort a female foetus in favour of trying for a male child. Or, a girl baby may be born with developmental problems if her mother has not had good care and nutrition during pregnancy. A girl may be undernourished, neglected, under-educated, and/or overworked as a child and youth, due to son preference, and continue so for the remainder of her life, increasing the risk of poor pregnancy outcomes when she reaches reproductive age. At any or all points in her life she might live in a violent environment and be the victim of some form of GBV, at the hands of her parents, brothers, husband, in-laws, and/ or employers.

Being a sensitive, painful, and personal issue, GBV, especially DV, often goes unreported. Furthermore, women are reluctant to talk about their private trauma, due to traditional and societal gender role norms, poor knowledge of legal and human rights, and lack of confidence in seeking help. If women do want to seek help, they often do not know where to go. If they do seek help for injuries, patients often do not disclose the violent cause, and they may suffer worse health consequences of injuries which are inadequately treated due to lack of disclosure about the true cause of the injury. Furthermore, without intervention, violence is likely to re-occur (Loi et al, 1999). 


\subsection{Viet Nam and its International and National Commitments to Address GBV}

The Socialist Republic of Viet Nam with a population of about 86.2 million (end of 2008), is located in the S-shaped strip of land along the Eastern side of the Indochina peninsula, bordering China to the north, Laos and Cambodia to the west, with a long coastline facing the Eastern Sea (South China Sea) and the Pacific Ocean to the east and south (MOFA, 2010).

Viet Nam was one of the first countries to ratify the Convention on the Elimination of All Forms of Discrimination against Women (CEDAW) in 1979, but it has not signed the Optional Protocol to CEDAW. The CEDAW was adopted by the United Nations General Assembly on 18 December 1979 , and became an international treaty on 3 September 1981. Since 1982, Viet Nam has been represented on the Committee on the Elimination of Discrimination against Women, a body of 23 independent experts from around the world that monitors implementation of the CEDAW in over 185 countries. As a member, Viet Nam is obliged to report to the Committee on how the rights spelled out in the Convention are being implemented. At least once every four years, Viet Nam is expected to submit a national report to the Committee, indicating the measures that have been adopted to achieve the provisions of the Convention.

Elimination of Discrimination against Women includes elimination of genderbased violence (GBV) among girl-children as well. In 1996 in Stockholm, at the First World Congress against Commercial Sexual Exploitation of Children, a Declaration and Agenda for Action was formulated and signed by representatives from 119 countries (UNICEF, ESCAP, ECPAT International, et al. 2001). Viet Nam was a signatory at the East Asia and the Pacific Regional Consultation for the Second World Congress against Commercial Sexual Exploitation of Children, held in Bangkok October, 2001. This meeting was attended by 252 representatives from countries that had adopted the Stockholm Declaration and Agenda for Action.
In June 2004, the Government of Viet Nam approved the amended Law on Child Protection, Care, and Education (UNICEF EAPRO, July 2005; UNICEF, ESCAP, ECPAT International, et al. 2001). This amended Law ratified the Stockholm Declaration and Agenda for Action against the Commercial Sexual Exploitation of Children. It states that "protection, care, and education are the responsibility of every citizen, the family and the State; and that all children are integrated into the family and the community." For the period 2005 - 2010, the Government of Viet Nam has developed National Strategies on Child Protection, Integrated Early Childhood Development, and Child Participation, which include efforts to strengthen the capacity of families to realize and respect the rights of children, women, and the elderly (UNICEF, ESCAP, ECPAT International, et al. 2001).

The 1996 Stockholm Declaration states that "poverty cannotbe used as a justification for the commercial sexual exploitation of children." Girl-child prostitution in Viet Nam is considered a crime, yet statistics show that $7 \%$ to $10.5 \%$ of the country's 200,000 prostitutes are children. These children are at risk for HIV/AIDS, pregnancy, drug and alcohol abuse, as well as physical and psychological violence. From 1991 to 1992, about 22,000 Vietnamese women were bought and sold, both in and out of Viet Nam. Vietnamese girls are trafficked to Cambodia and Thailand for prostitution and also to China and Hong Kong as domestic workers (Viet Nam Country Progress Report, 2004). In response to increasing attention to the issue of violence against women in Viet Nam, on November 21, 2007, the Viet Nam National Assembly passed the Law on Domestic Violence Prevention and Control.

\subsection{Studies and Projects on Gender-Based Violence and Domestic Violence in Viet Nam}

Like most other countries, Viet Nam does not have comprehensive data on GBV. However, several sources of data indicate that this problem is widespread, and even increasing. The first study of domestic 
violence (DV) in Viet Nam was reported by the Population Council Viet Nam (PCVN) in 1998 in a qualitative report entitled, "Violence and its consequences for reproductive health." Factors reported to be associated with DV included: alcohol, drug abuse, gambling, stress/frustration, mental illness, and son preference. The issue of forced sex in marriage was also raised in focus group discussions, which revealed that women saw it as a problem but "tolerable," while men did not consider it an issue to be discussed seriously. This report was based on recorded interviews among women clients of the Ho Chi Minh City (HCMC) Counselling Centre and its anonymous "hotline" counselling (Mai, 1998; Mai and Landfield, 1999). Other small-scale mainly qualitative research on DV indicates that DV occurs in both urban and rural settings, and at all social strata (Loi et al., 1999).

In 2002, within the framework of the demographic surveillance in Ba Vi District (rural northern $\mathrm{Ha} \mathrm{Noi}$ ), 37 clusters were selected through a random cluster sampling technique from a cohort of approximately 50,000 individuals (69 clusters), to investigate the impact of DV on women's health (Nguyen et al, 2008). A number of households were selected from each cluster, proportional to the total number per cluster. Married or partnered women ages 17 to 60 years were selected in this first population-based study to investigate type, severity, and risk factors of DV against women. Instruments for data collection originated from a questionnaire developed in the World Health Organization's Multi-country Study on Women's Health and Life Experiences. A sample of 883 women aged 17 to 60, all claiming to be married, were interviewed. Findings showed that the lifetime prevalence of physical violence among the interviewed women was 30.9\% and the past-year prevalence was $8.3 \%$, while the corresponding prevalence for physical and sexual violence combined was $32.7 \%$ (lifetime) and $9.2 \%$, (past year). The lifetime prevalence for psychological violence was $27.9 \%$. In most cases, the psychological violence was severe and persistent (repeated over time).
For lifetime and past-year occurrence of physical and sexual violence, three main associated factors were:

(1) low educational levels of women and their partners/husbands,

(2) low household income, and

(3) man having more than one wife/ partner.

For psychological violence, the risk factors were:

(1) husband/partner has low professional status, and

(2) wife/woman has intermediate level of education

Polygamy is still practiced in rural areas although it became illegal in 1960; and officially the country has new laws on Gender Equality and on Marriage and Family that abolish polygamy. Women's lack of knowledge about these laws, especially in rural and poor areas, make polygamous relationships a common factor associated with DV (Nguyen et al., 2008). Supreme Court statistics indicate that nearly $60 \%$ of divorces are due to maltreatment of the wife, and this figure is rising over time. The statistics of a counselling centre in Ho Chi Minh City (HCMC) show that DV is the subject of approximately $30 \%$ of the calls they receive. Similarly, the number of calls made to the Hotline 1088 counselling centre in $\mathrm{Ha}$ Noi which relate to DV has doubled to 6,000 calls in 2004, up from 3,000 calls in 1997 (The Population Council, 2000; Mai, 2005).

Clearly, married women in rural Viet Nam are heavily exposed to all forms of serious, repeated abuse from their husbands or male partners. DV not only affected women's health but also that of their children and other family members, thus constituting a serious violation of women's rights. Given the substantial prevalence of GBV in Viet Nam, HCPs could play an important role because of 
their access to the general population as patients, providing an opportunity to screen for DV (early detection). However, HCPs at all levels need appropriate training in: how to address victimized women and their partners; how to deliver counselling; and how to pose sensitive questions to probe violence (Nguyen et al, 2008).

\subsection{Moving Forward to Improve GBV Prevention and Care Services in Viet Nam}

The results of studies mentioned above show widespread DV in Viet Nam. Recently, actions to improve the situation for women have begun to be discussed in the mass media. Although GBV is now being treated as a social issue, is now regulated by law, and is drawing much attention from local authorities and organizations, the number of organizations providing services is small. Only in the large cities of $\mathrm{Ha}$ Noi and $\mathrm{HCMC}$ victims of DV can seek help from trained GBV counsellors. Moreover, the participation of health personnel, legal agencies, and the police, all of whom play important roles in the health and safety of victims, have been almost absent (Centre for Reproductive Health and Family, 2000; Viet Nam Women's Union, 2001; The Population Council, 2000).

In May 2006, the Consultation of Investment in Health Promotion (CIHP), a local NGO, initiated a 30-month "Integrated Model for Responding to Gender-Based Violence in Clinic and Community Settings" in seven communities in Cua Lo town, Nghe An province, with support from the Ford Foundation. The $\mathrm{ClHP}$ network organized hundreds of behavioural change communication (BCC) sessions for local men and women, and disseminated various information, education, and communication (IEC) materials, including true stories of DV, through local newspapers, radio, and television. Reported outcomes included: increasing percentage of women visiting district hospitals were screened for possible GBV and significant number of counselling sessions for abused women. The expanded word of mouth among women victims of DV encouraged more abused women to seek support and consider options to change a relationship with an abusive partner $(\mathrm{Ha}$, Hoang and Quach, 2009). Consequently, local authorities began to take concrete actions, such as sanctions against abusive men and fines for second or third offenders. Other sanctions were mandatory reeducation sessions on Law on Domestic Violence Prevention and Control (which was issued in 2007) or community service in the commune.

Another model for DV prevention in 16 communes in Doan Hung district of Phu Tho province, and Binh Dai district of Ben Tre province was piloted by the United Nations Population Fund (UNFPA) Viet Nam. Activities included providing GBV screening and counselling at district hospitals, and examining referral to other services such as reconciliation teams, police, courts, and the Women's Union. Target groups are local authorities, police officers and the justice system, health care providers, women and men, and young people, as well as perpetrators and victims of violence. Target policy making bodies include the Ministry of Culture, Sport, and Tourism (MOCST), $\mathrm{MOH}$, the National Assembly, the Viet Nam Communist Party, and the General Statistics Office (GSO) (Vietnam.unfpa. org/gender.htm). 


\section{PRE-INTERVENTION ASSESSMENT STUDY AMONG HEALTH CARE PROVIDERS}

The May 2009 pre-intervention assessment of HCPs perception and needs for a GBV screening training, and time for application of their new knowledge and skills, including the new treatment guidelines was carried out among 400 hospital staff at four hospitals in Da Nang and Ho Chi Minh City (HCMC), with the following objectives and methods.

\subsection{Objectives and Methods}

\subsubsection{Study Objectives - To assess:}

1) GBV-related awareness, attitudes, and practices of HCPs, especially on DV and rape of women and girls;

2) Treatment and support available for patients who are victims of violence, and HCPs' experience in assisting GBV victims;

3) Interests and needs of HCPs in terms of training about GBV screening and treatment guidelines, as a potential intervention.

\subsubsection{Methods}

A baseline assessment survey was conducted in four hospitals ( $\mathrm{Da}$ Nang hospital and Cam Le hospital in Da Nang, and Nguyen Tri Phuong hospital and Thu Duc hospital in HCMC). Face to face interviews were conducted with 400 hospital staff, 200 in each city. The HCPs' characteristics are presented in Table 3.1 (questionnaire is attached in Appendix 2). Questions focused on:

What are HCPs' perceptions of the situation of GBV in the area?

How do HCPs identify and assist GBV victims among their female patients?
How do HCPs and relevant departments/ agencies coordinate their work on issues of GBV, and what kind of support is needed?

In addition, four focus group discussions (FGDs) were done, one at each hospital (with 9 to 10 respondents), plus ten in-depth interviews (IDIs) with senior hospital staff: 3 at Da Nang hospital (2 male and 1 female respondents); 2 at Cam Le hospital (2 male respondents); 3 at Nguyen Tri Phuong hospital ( 2 male and 1 female respondents); and 2 at Thu Duc hospital $(1$ male and 1 female respondent). The respondents of the FGDs and IDIs were individuals at the policy-making level from the Obstetrics and Gynaecology Departments, Emergency Units, Surgery, and Trauma Centres, including Deputy Directors and Hospital Directors (all were physicians, except one nurse). Respondents were informed about the intended intervention and the purpose of the assessment study. Participation was voluntary and identities were kept confidential.

Quantitative data were processed using SPSS to show any correlations amongst the awareness, attitudes, and support activities for GBV victims and characteristics of the HCPs (e.g., age, gender). Qualitative data were analyzed to help explain and illustrate findings of the quantitative analysis.

\subsection{Results of the May 2009 Pre-Intervention Assessment Survey}

\subsubsection{Socio-Demographic Characteristics of HCPS}

Table 3.1 shows that out of 400 health care providers (HCPs) participating in the survey, most were female (78\%), most were young (only $32 \%$ aged over 40 ), and about one quarter were physicians. Half of the HCPs had worked in the health sector for less than 10 years (52\%). HCPs in Da Nang were on average older, more likely to be married, and mostly physicians, compared to the HCPs in HCMC. 
Table 3.1. Socio-demographic characteristics of HCPs, $n=400$ (\%)

\begin{tabular}{|c|c|c|c|}
\hline Characteristics & Da Nang & HСMC & Total \\
\hline \multicolumn{4}{|l|}{ Gender } \\
\hline Male & 24.0 & 20.0 & 22.0 \\
\hline Female & 76.0 & 80.0 & 78.0 \\
\hline \multicolumn{4}{|l|}{ Age } \\
\hline 20 - 30 years & 27.0 & 57.5 & 42.5 \\
\hline $31-40$ years & 32.0 & 19.5 & 25.5 \\
\hline$>40$ years & 41.0 & 23.0 & 32.0 \\
\hline \multicolumn{4}{|l|}{ Professional qualification } \\
\hline Physicians & 30.5 & 19.1 & 24.8 \\
\hline Physician Assistants & 7.5 & 6.5 & 7.0 \\
\hline Midwives & 12.5 & 15.6 & 14.2 \\
\hline Nurses & 44.5 & 55.8 & 50.0 \\
\hline Others (e.g., orderly, technician) & 5.0 & 3.0 & 4.0 \\
\hline \multicolumn{4}{|c|}{ Years working in health sector } \\
\hline Below 10 years & 47.5 & 71.5 & 52.2 \\
\hline $10-20$ years & 31.5 & 16.0 & 27.0 \\
\hline$>20$ years & 25.6 & 12.5 & 20.8 \\
\hline \multicolumn{4}{|l|}{ Department } \\
\hline Medical & 19.9 & 21.6 & NA \\
\hline Emergency & 3.7 & 21.6 & NA \\
\hline Obstetrics \& Gynaecology & 16.2 & 17.6 & NA \\
\hline Surgical & 30.9 & 31.7 & NA \\
\hline $\begin{array}{l}\text { Other (e.g., Internal, Paediatrics, } \\
\text { Cardiovascular) }\end{array}$ & 29.3 & 7.5 & NA \\
\hline \multicolumn{4}{|l|}{ Marital status } \\
\hline Single & 18.0 & 50.0 & 34.0 \\
\hline Married & 81.0 & 48.5 & 64.8 \\
\hline Divorced & 1.0 & 1.5 & 1.2 \\
\hline
\end{tabular}




\subsubsection{Knowledge and Attitudes of HCPs about GBV}

\subsubsection{General Knowledge and Attitudes about} Gender and GBV

Culture and traditions influence behaviours in marital relationships, including the perceptions about different roles of husbands and wives. Overall, 23.3\% of respondents stated that, "man should be the head of the family and the decisionmaker." This figure was much higher in Da Nang (38.0\%) than in HCMC (8.5\%). A substantial number of respondents also felt that men should show that they are the "boss" in certain circumstances (Da Nang 15.0\%; HCMC 25.5\%). Interestingly, the majority of respondents rejected the statements that, "a good wife should listen to her husband even if she does not agree with his ideas and behaviours," and "a woman is obliged to have sex with her husband even if she doesn't want to." The percentage of respondents agreeing with these statements in Da Nang is 9.0\% and $9.5 \%$, respectively, and in $\mathrm{HCMC}$, only $4.0 \%$ and $5.0 \%$, respectively. Most HCPs agreed that family conflicts should be settled in a family setting $(67.0 \%$ in $\mathrm{Da}$ Nang; $66.0 \%$ in $\mathrm{HCMC}$ ), although one out of four respondents said this would depend on the circumstances (24\%; $26 \%)$. The majority of respondents were aware that intervention by outsiders would be needed if a husband beats his wife often $(82.0 \%$; 78.0\%). Please see Figure 3.1 below (details are in Table A, Appendix 1).

\section{Figure 3.1. Knowledge and attitudes of HCPs about gender and GBV}

\section{\% HPCs agree}

Should be dealt within family setting

A woman has a right to refuse to have sex with her husband if she doesn't want to

A man should demonstrate to his wife that he is the head of the family (the boss)

There should be external interventions if the man always beat his wife

HCMC

Da Nang

Older HCPs and men were more likely to endorse statements about the dominant role of men in the family. However, more female than male respondents in all four hospitals agreed with the statement, "women must meet their husband's sexual needs" $111.2 \%$ versus $4.2 \%$ in Da Nang, and $5.6 \%$ versus $2.5 \%$ in HCMC, for men and women respectively).

In general, HCPs disagree that men have the "right" to beat their wives in any circumstances and for any reason. In fact, a high proportion of respondents said it is wrong for a man to beat his wife for failing to

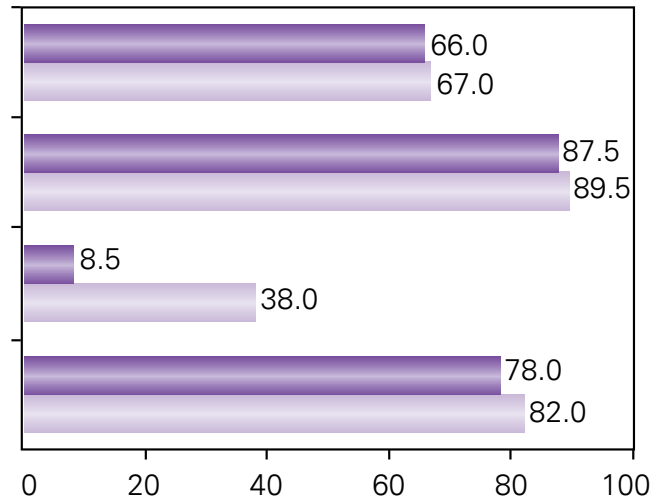

meet his expectations for housework (94\% in HCMC; $91.9 \%$ in Da Nang). Even if the wife is a gambler or addict, $75.9 \%$ of respondents in Da Nang and $74.5 \%$ in HCMC reject the husband's habit of beating his wife. Almost $94 \%$ of respondents in both project areas oppose violence towards wives who refuse sex. A fraction of respondents $16.1 \%$ in Da Nang; $13.6 \%$ in HCMC) say "Yes" to a husband's beating his wife if she insults or swears at her husband. About 25.1\% of respondents in Da Nang and 13.1\% in HCMC agree that a husband can beat his wife if she has an extramarital affair. The majority of 
respondents believe that a woman has the right to decline sex with her husband if she is tired (98\% in Da Nang; 95\% in HCMC); if the husband is drunk $(90.5 \%$; $86.5 \%)$; or when the husband has been abusive to her (92.5\%; 91.5\%).

The FGD and IDI results indicated that although few respondents were able to give a comprehensive definition of GBV, most of them could mention various forms, i.e., physical and psychological mistreatment, economic control, and abandonment. A female HCP said, "GBV is about issues between men and women, such as mistreatment or injury of women by men, or psychological trauma." Another female FGD respondent described, "GBV includes physical and psychological violence; i.e., men controlling women, women controlling men, men controlling their wives and children." Another depiction was, "GBV is mistreatment against women, like in a marriage a woman has no right to choose her partner and no power in spending; a wife has to stay home, do the housework. If he shows disregard or neglects his wife, that is maltreatment."

\subsubsection{Knowledge and attitudes about} domestic violence Behaviours perceived as domestic violence
Respondents were read a list of behaviours and asked to say whether or not they considered them as domestic violence (DV). Physical violence was the form of DV most often identified by respondents. Almost $100 \%$ of respondents (HCPs) agreed that physical violence against women should be defined as GBV, including assault that causes injury to women (99.0\%); using sticks and dangerous objects to beat and cut women $(99.5 \%)$; and beating during pregnancy $(100 \%)$.

Majority of respondents also identified psychological abuse as GBV, namely, scolding or insulting $(97.5 \%$ in Da Nang; $74.0 \%$ in $\mathrm{HCMC}$ ); and threatening and controlling (94.0\% in Da Nang and HCMC). However, there was a striking difference in opinions about other types of maltreatment between respondents in $\mathrm{Da}$ Nang and HCMC. For instance, while $94.5 \%$ of respondents in Da Nang think that sending a wife away from home qualifies as GBV, just $66.5 \%$ of respondents in HCMC agreed. Similarly, regarding preventing women from participating in social activities, contacting relatives and friends, and getting medical treatment, in Da Nang, 78.5\%, 79.5\%, $90.5 \%$, respectively, agreed that these were forms of GBV, while in HCMC only $46 \%, 55.5 \%, 75 \%$ agreed, respectively (see Table B, Appendix 1).

\section{Figure 3.2. HCPs identifying specific behaviours as DV or GBV (\%)}

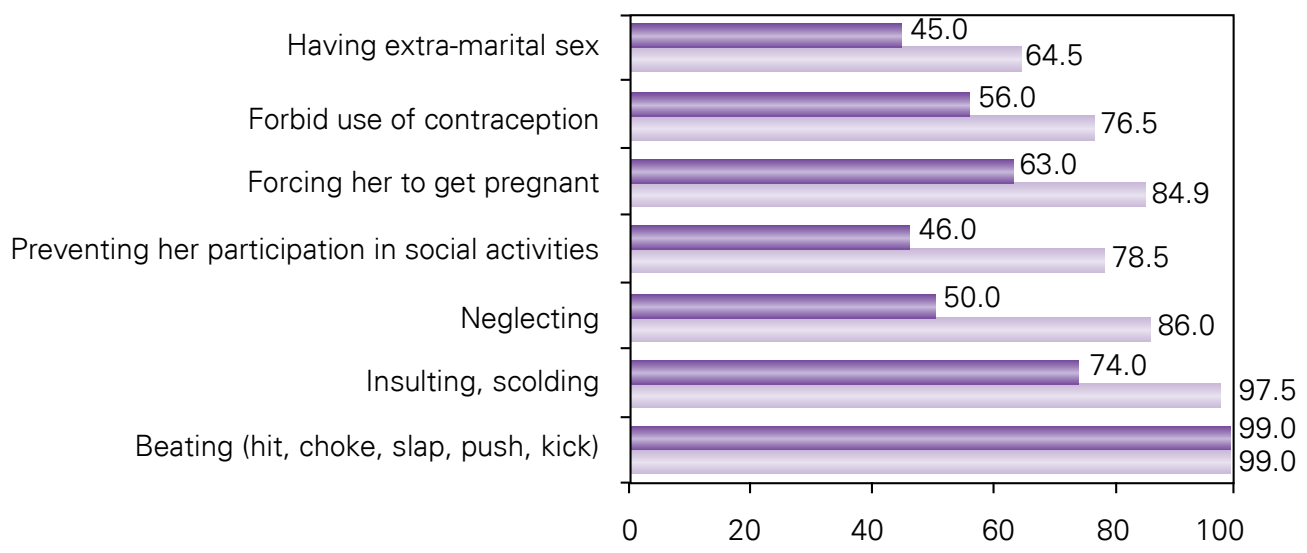

$\mathrm{HCMC}$

Da Nang 
In relation to reproductive health and rights, $56 \%$ and $76.5 \%$ of respondents in $\mathrm{HCMC}$ and in Da Nang respectively, believed that not allowing a wife to use contraceptives counts as DV. The proportions in each city did not differ substantially by gender of the respondent. Similarly, forcing a wife to have sex against her will was identified as DV among $88 \%$ of respondents in $\mathrm{Da}$ Nang and $80 \%$ in HCMC. The proportion of women respondents who considered having extramarital sexual affairs to be DV is higher than that of men in both study locations $(67.1 \%$ versus $56.3 \%$ in Da Nang; $46.9 \%$ versus $37.5 \%$ in $\mathrm{HCMC}$ ).

Based on findings from the FGDs and IDIs, four main types of DV were identified: physical, psychological, sexual violence and economic violence. One male respondent said, "DV includes the behaviours of men which cause physical and psychological wounds to women. This includes making women sad and worried and making them leave home, and beating women." A female respondent identified other forms of DV, "causing physical hurt or humiliation to women, dominating family economic, money, or other valuables, and putting pressure on women."

Wives, daughters-in-law, and daughters, were all identified by FGD and IDI respondents as common targets of various forms of DV. The most commonly mentioned form of DV was husband against wife. A male respondent said, "I think in Vietnamese families women suffer more maltreatment and violent behaviours." But a female HCP added, “... a narrow perspective, DV occurs between husband and wife. But there is also children's maltreatment of their mothers, and abuse among siblings. It is not limited to physical violence like beating, but includes sexual and psychological violence." A male respondent said, "[lt includes] brothers beating sisters, children abusing their mothers, and grandchildren against grandparents."

\section{Perceived severity of domestic violence behaviours}

Opinions varied about the seriousness of different DV behaviours. Physical violence was viewed as most serious, especially beating women $(49 \%$ in $\mathrm{Da}$ Nang; $37.5 \%$ in $\mathrm{HCMC}$ ), beating pregnant women (93\%; 84.5\%); and using sticks and dangerous objects to beat women (86\%; 77.5\%). Fewer HCPs considered psychological violence to be serious. Only $26 \%$ of respondents in Da Nang and 20\% in HCMC think that humiliation by scolding and insults is very serious; and $45 \%$ in $\mathrm{Da}$ Nang versus $19 \%$ in $\mathrm{HCMC}$ think sending women away from home is very serious. See Figures 3.3 and 3.4.

\section{Figure 3.3. Perceived severity of domestic violence behaviours - Da Nang}

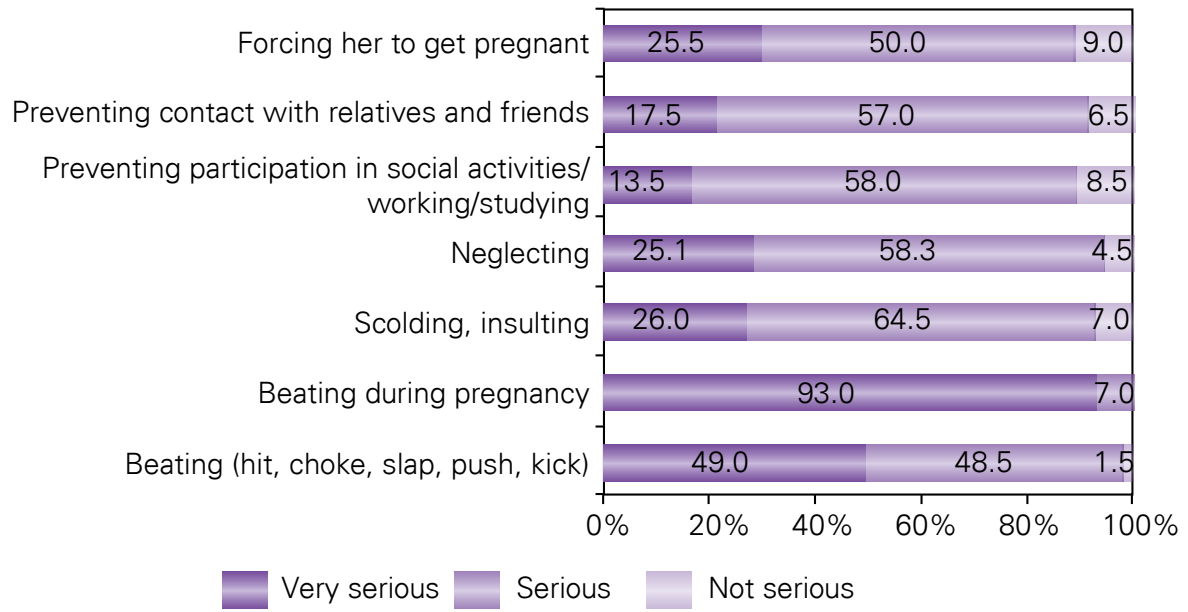




\section{Figure 3.4. Perceived severity of domestic violence behaviours - HCMC}

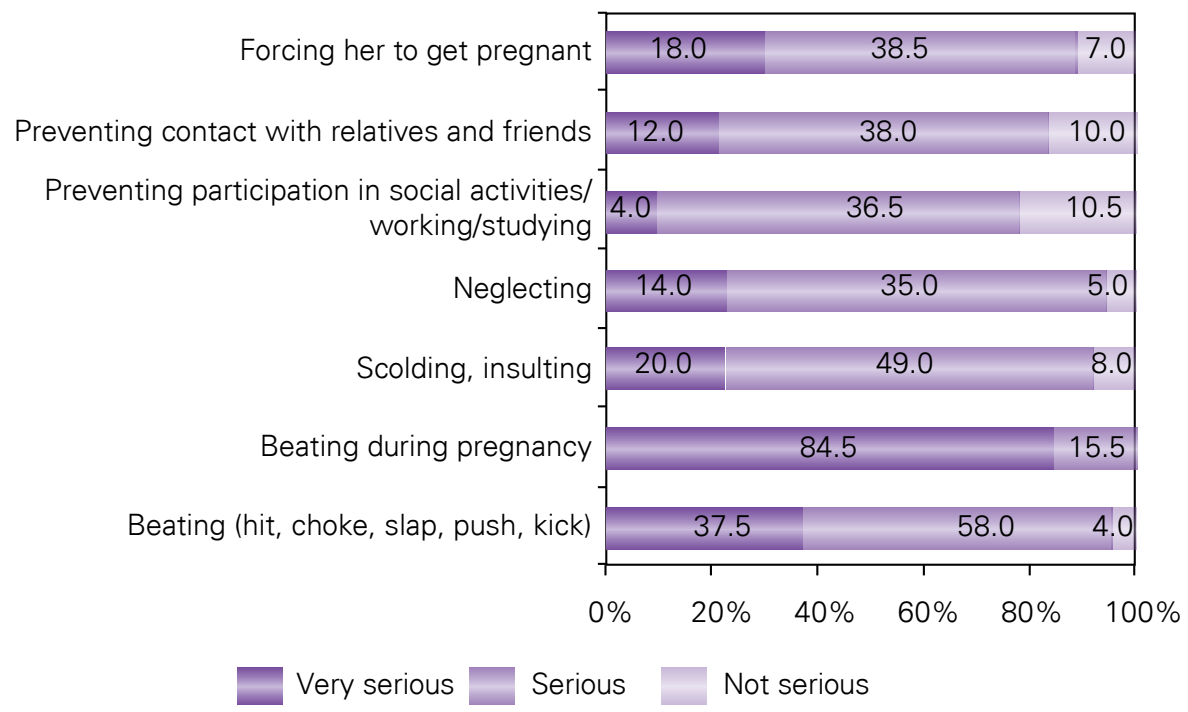

In general, almost all forms of physical and psychological violence were considered to be serious or very serious. In each case, the proportion of HCPs who considered the listed behaviours to be very serious was smaller in HCMC than in $\mathrm{Da}$ Nang (Table C, Appendix 1).

Women respondents were more likely than men to judge each form of violent behaviour as very serious. In HCMC, more women than men gave this label to assaulting (38.1\% versus $35.0 \%)$; beating pregnant women $(85.6 \%$ versus $80.0 \%)$; hitting women with sticks or dangerous objects $(80.0 \%$ versus $67.5 \%)$; scolding and insulting $(23.1 \%$ versus $7.5 \%)$; neglect (16.9\% versus 5.0\%); and forcing to give birth $(20.6 \%$ versus $7.5 \%)$. The data in Da Nang were similar. FGD and IDI participants in both project areas also provided similar responses. The majority agreed that all forms of DV have serious consequences for victims. However, they tended to emphasize the greater seriousness of physical violence.

At least half of respondents rate unprotected sexual violence (no contraception) as serious or very serious (71.5\% in Da Nang; $50.0 \%$ in HCMC). Likewise, about $84.5 \%$ of respondents in

Da Nang and $70.0 \%$ in HCMC rate coercing to have unwanted sex as serious or very serious; $68.5 \%$ in Da Nang and $49.0 \%$ in $\mathrm{HCMC}$ consider having extramarital sexual relationships as serious or very serious.

\section{Causes and consequences of domestic violence}

Economic causes have been documented in previous studies as the causes of DV, with about half of respondents mentioning economic issues as a source of conflict. When asked if they knew of any causes of DV, approximately half of the participating HCPs in both locations mentioned economic issues, while about half also mentioned other problems including extramarital affairs, gambling/drunkenness/ drug use, and other marital conflict (Figure 3.5). Other issues identified by fewer respondents as causes of DV included conflict over children's education $(<15 \%)$, marital sexual issues $(<20 \%)$, conflict between wife and in-laws $(<25 \%)$, and effects of the male superiority belief $(\leq 30 \%)$.

There were notable differences of opinion between HCPs in Da Nang and $\mathrm{HCMC}$ on two of the potential causes of DV. An extramarital affair by one spouse was noted as a cause by $52.5 \%$ of participants 
in Da Nang, versus just 38.5\% in HCMC. Similarly, gambling/drunkenness/drug use was mentioned by $54.5 \%$ in Da Nang, but was only cited by $43.5 \%$ in HCMC.
On other issues, the proportions of respondents identifying them as causes of DV were similar between the two locations (less than 10\% difference in rates).

\section{Figure 3.5. Causes of domestic violence mentioned by participants (\%)}

Note: $2.0-4.0 \%$ said they don't know/gave no answer.

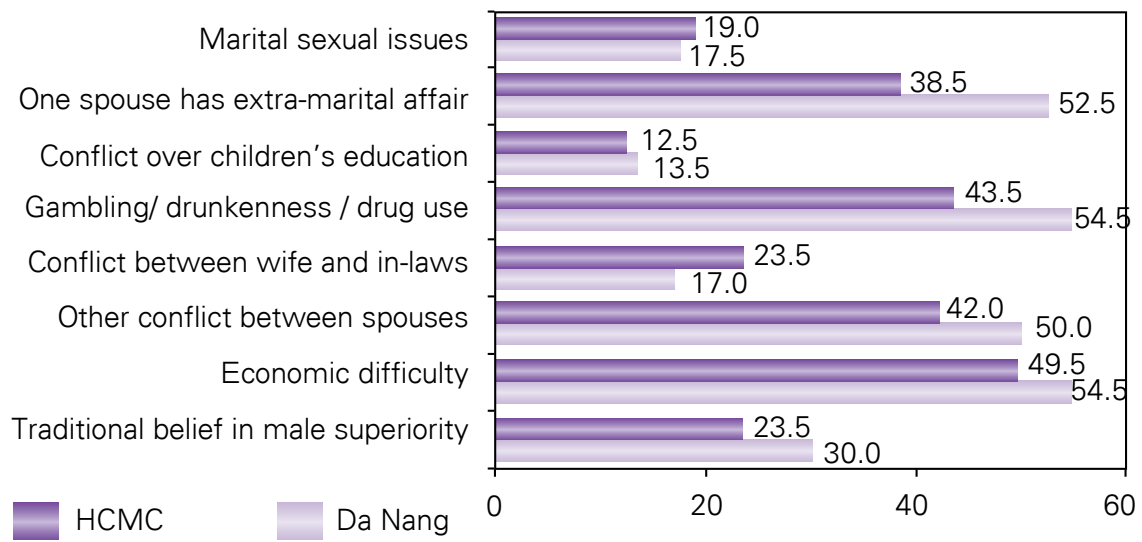

The most notable difference by gender of respondents in opinions about causes of DV was that in $\mathrm{HCMC}$, men were much more likely than women to identify economic problems as a cause of DV $(65.5 \%$ versus $45.6 \%)$.

In FGDs and IDIs, the belief that men are superior to women was identified as a root cause of DV. One male participant said, "The root cause is male chauvinism." This belief is particularly strong in rural areas. Another male participant explained, "From the time of feudalism to the present, men have been superior to women and son preference is embraced by many. Equality does not really exist. In fact, my relatives in rural areas still hold this view."

Son preference can lead to forcing a wife to have more children until she bears a son to continue the male line. This can seriously impact women's health, and also increase the domestic workload and economic burden. A female FGD participant described one case, "[Her] husband forced her to give birth to a son, who should support him in his old age. This is required as a form of a wife's love to her husband. Therefore, although she was 44 years old, she tried to get pregnant, hoping to have a boy. It is really hard on her. It made her health poorer, and put her life at risk, just to meet her husband's desire for a son." Beliefs about male superiority persist among well-educated men of high status. One male participant admitted, "The feudal beliefs still remain, so maltreatment [against women] still exists. We, men, still believe that women must submit to men. We read books and newspapers, even go abroad and hear about equality between men and women, but at heart we still believe [in the superiority of men]. We grew up in families with parents and friends who held such beliefs."

Low educational attainment was also repeatedly identified as a root cause of DV. One female participant at Thu Duc hospital said, "Those with poor schooling are not aware that their behaviour is violent. They do not admit any wrong-doing, so the victims must endure."

Economic difficulties, including debts and poverty, are recognized as the cause of stress which leads to quarrelling and beating. Social problems like gambling, drunkenness, and lack of knowledge 
exacerbate the problems. The economic dependence of women in the family keeps them in a subordinate position. As described by a male participant, "In some families, when the wife does not contribute to the family economy, even she does housework well, she is considered a 'freeloader.' The husband, thinking that he feeds the family, has absolute power and always shows his superiority."

The opinions expressed in the FGDs and IDIs, as well as on the questionnaire responses, indicate that alcohol and other social problems are amongst the causes of DV. In both study locations, it was commonly said that men only beat their wives when drunk. As one male FGD participant said, "After working hours, a man drinks wine with his friends, gets drunk, and he might hit his wife when he gets home, instead of giving her money. Drinking is closely associated with domestic violence."
Other causes, including extramarital affairs, difference in lifestyles or conflicts caused by involuntary marriage were also identified.

The consequences of DV against women are evident. The collected data document a wide range of negative physical and psychological effects on the victims, their families and children, as viewed by the respondents. The survey questionnaire provided a set of choices regarding potential consequences. The responses focus mainly on physical health and safety $190.5 \%$ in HCMC; $86.0 \%$ in Da Nang); followed with mental health $(88.5 \%$; 83.5\%); family happiness $(40.5 \% ; 65.5 \%)$; and child development (37.0\%; 53.5\%). Other less commonly identified consequences are impact on family economy and reproductive health (see Fig. 3.6).

\section{Figure 3.6. Consequences of domestic violence (\%)}

Note: $0.5-2.5 \%$ said they don't know/gave no answer

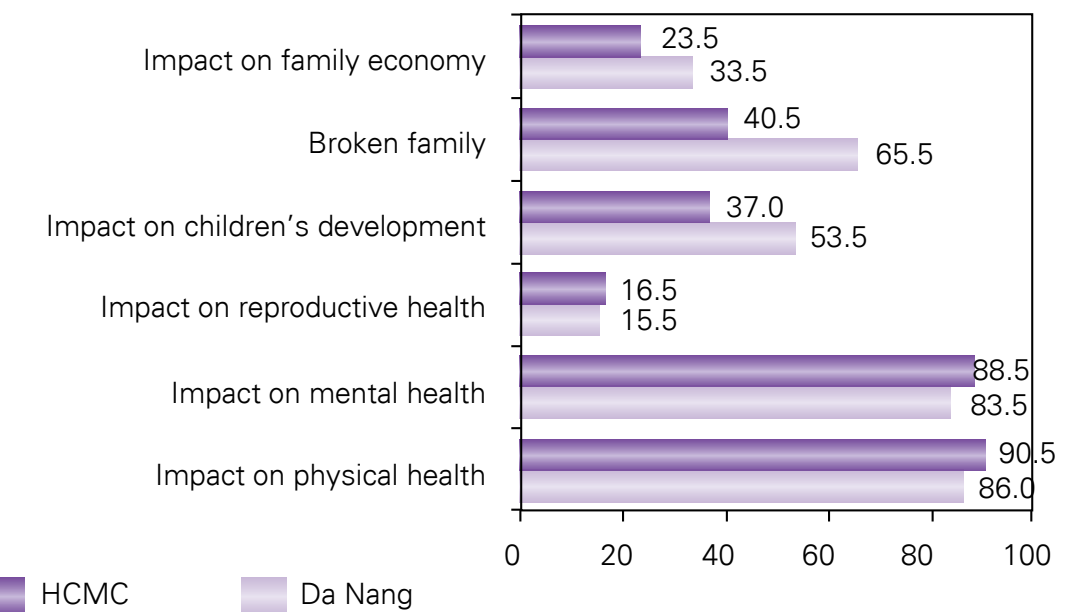

Analyzing the perceived consequences of $\mathrm{DV}$ by gender of respondents, men in HCMC were more likely than women to mention the impact on physical health (97.5\% versus $88.8 \%$ ). In Da Nang, this gender difference was less pronounced (89.6\% versus 84.9\%). In both cities, women more often than men mentioned

consequences to the development of children: $39.4 \%$ versus $27.5 \%$ in HCMC; $62.5 \%$ versus $50.7 \%$ in Da Nang. Women were also much more likely to mention the negative consequences for reproductive health (34.2\% versus 15.8\%) and family economy (31.3\% versus $14.6 \%$ ). 
Qualitative data from the FGDs and IDIs provide more information about each of these potential consequences of DV. Some of the specific consequences mentioned are intense moods, family instability, and injuries. A male respondent at $\mathrm{Da}$ Nang hospital said, "Physical violence absolutely has physical consequences. In hospital, I saw women who had been beaten by their husbands and gave birth prematurely or miscarried. Psychological violence plunges women into sorrow, insomnia, sense of inferiority and isolation. All these may lead to other consequences in the long run, including chronic conditions such as hypertension, colitis." A female participant added, "The women who are physically maltreated, and psychologically abused, are prone to sadness and isolation or withdrawal (depression) and illness." A male FGD participant mentioned other consequences: "First, it has adverse impact on marriage. Second, it possibly makes the family fall into poverty."

When men excessively maltreat their wives, divorce is a likely outcome, and this has far-reaching consequences. A female FGD participant said, "Divorce is the last resort. It breaks a family." Meanwhile, a male FGD participant said, "When women cannot bear it, they accept break-up. Children in such families suffer a lot." Many assert that children suffer most from all types of DV, leaving them with long-term mental trauma. As one male respondent explained, "Definitely, DV has impact on children, ... all negative. Daughters living in violent families are inclined to accept violence when they grow up. Sons ...might become violent to their wives when they marry."

\subsubsection{Knowledge and attitudes about rape and sexual assault}

Sexual coercion, including rape against women and girls, is another aspect of GBV. Although rape is a serious concern, it apparently occurs rarely in some localities, and not all HCPs have met or treated rape victims. Even so, almost all respondents (99.5\% in Da Nang, and $99.0 \%$ in HCMC) agreed that rape is a form of mistreatment against women (1 and 2 respondents, respectively, disagreed). Also, 99.0\% of respondents in Da Nang and 95\% in HCMC said rape of girl children is a form of mistreatment (in Da Nang, 1 disagreed, and 1 gave no answer; in $\mathrm{HCMC}, 7$ disagreed, and 3 gave no answer). Regarding severity of rape, in Da Nang, 99\% said rape of a girl child was very serious and $1 \%$ said serious, while in $\mathrm{HCMC}$, only $90.5 \%$ said this was very serious, $5.5 \%$ said serious, and $4 \%$ did not answer. Also in Da Nang, $98 \%$ said rape of a woman is very serious, while $1.5 \%$ said serious and $0.5 \%$ (1 person) said it was not serious. In $\mathrm{HCMC}$, only $86.5 \%$ considered rape of a woman as very serious, $12.5 \%$ said serious, and 1\% (2 respondents) gave no answer.

Respondents say that sexual assaults against women and girls are caused by pornographic movies $164.5 \%$ of respondents in $\mathrm{Da}$ Nang, $51 \%$ in $\mathrm{HCMC}$ ), drunkenness/drug use $(54.0 \% ; 43.5 \%)$ and changes in morals $(9.5 \% ; 21.5 \%)$. There are no notable differences in these figures by gender of respondent. This behaviour is rarer than other forms of GBV, according to FGD and IDI respondents, based on their observations and experience of treating victims of sexual assault. A male respondent said, "Some people behave violently after aphrodisiac pills." A male FGD participant said, "I think they are psycho. They should be penalised for their violent behaviour." Some respondents blamed pornographic movies accessible through the internet, saying that, "There is plenty on the internet. My husband says there are numerous sex clips."

Perceptions of the consequences of rape are shown in Figure 3.7. Negative effects on mental health are the main perceived consequence $193.5 \%$ in $\mathrm{Da}$ Nang; $95.5 \%$ in $\mathrm{HCMC}$ ), and, to a lesser extent, effects on physical health. 


\section{Figure 3.7. Consequences of rape in women and girls (\%)}

Note: $0.5-2.0 \%$ said they don't know/gave no answer

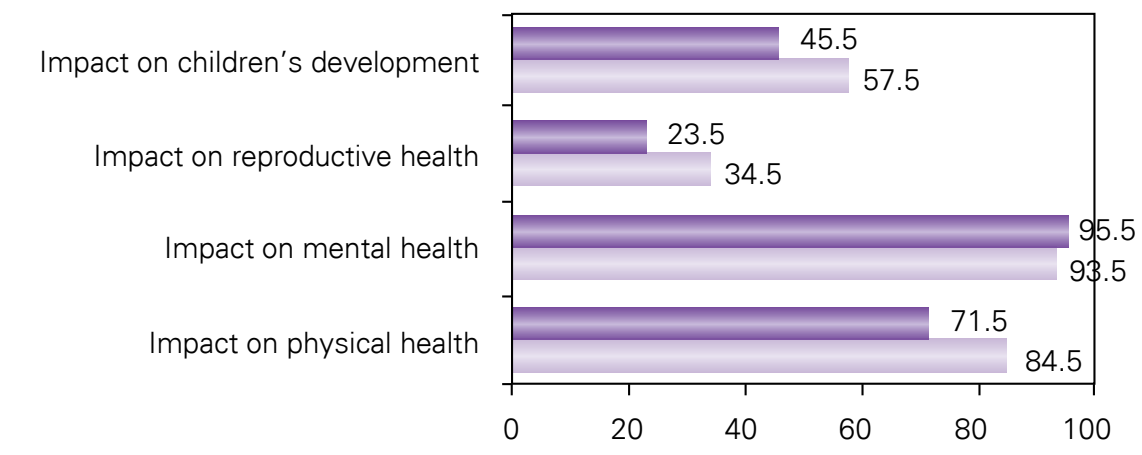

HCMC

Da Nang

Qualitative findings supported the quantitative data. Although the incidence of rape of women and girls is lower than other types of GBV, the consequences of this type of violence are viewed as very serious, especially for young girl victims. A female respondent said, "I think it is very serious. A girl at 4 or 5 years old who is raped will have serious mental trauma." A female FGD respondent said, "girls who are raped can develop malformations; for example, a girl who came to be examined at our hospital couldn't stretch her body, arms and legs. Some raped girls suffer afterward from mental illness. Others, get pregnant and have to give birth. It is really pitiful." Respondents recognized that the negative effects on physical and mental health can be long-term.

\subsubsection{Knowledge of GBV-related laws and regulations}

Having knowledge on the laws on DV or GBV is essential for HCPs who treat victims. But many do not know enough. Only $41 \%$ of respondents in $\mathrm{Da}$ Nang and $67 \%$ of those in HCMC said, "Yes" about whether they knew of any laws or regulations aimed at prevention and treating GBV. Qualitative findings also indicate very few respondents had directly read relevant legal information.
Many respondents admitted that although they had heard about the new Law on DV, they do not know the clauses (details) or articles defining the GBV violent behaviour. They have heard about the laws on TV, but they cannot name the laws, or the associated penalties for different violations. A male FGD respondent explained, "I've only known about it for a few months. I started to be concerned about this issue recently when documentaries on GBV were aired. After that, there was a law on DV, but I haven't studied it."

Some respondents who have accessed relevant documents and learned about intervention expressed positive support to help GBV victims. A male respondent said, "I know some articles of the law... if a husband beats his wife or maltreats her, the wife can report it to the authority. If it is a serious beating, she can report it to police. In case of serious violence, the wife will be sent for forensic tests." One female respondent who seemed to be well informed, said, "I've read the law on violence prevention or DV. This law was promulgated in November 2007 and came into effect on July 1, 2008. I've read every word of the law. I know that the law on family and gender is also an important law. I learned about gender equality issues because I often read Phu $\mathrm{Nu}$ (Women) newspaper. My family buys 
Phu Nu newspaper and Phu Nu TP HCM (HCMC Women) newspaper almost daily. I'm concerned about gender equality, but I think we mostly focus on gender equality in the workplace, and not on DV."

Figure 3.8 shows the responses of the HCPs who said they knew about laws aimed at controlling GBV, grouped by which kinds of GBV behaviours they believed to be controlled under current laws or regulations. Responses differed between Da Nang and HCMC. The respondents in Da Nang were more likely to know about GBV-related laws pertaining to physical violent crimes $(74.4 \%$ versus $59.7 \%)$, verbal abuse $(35.4 \%$ versus $29.9 \%)$, violation of monogamy law $(18.3 \%$ versus $10.4 \%)$ but less likely to name rape than HCMC HCPs (69.5\% versus 92.5\%).

\section{Figure 3.8. HCPs able to mention violent behaviours regulated by laws}

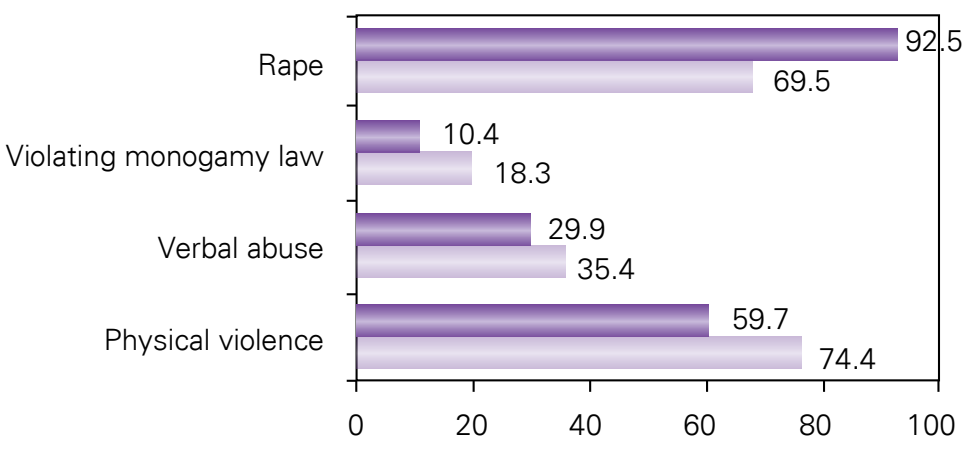

\section{HCMC Da Nang}

Just $41 \%$ of HCPs in both study locations (approximately equivalent for men and women) knew about the 2007 Law on DV, and knowledge of other relevant documents, such as the Law on Gender Equality, was similarly low. One FGD respondent admitted, "[I] don't know about the Law on Domestic Violence. I thought laws on GBV and gender equality did not exist." Only $9.8 \%$ of respondents in HCMC and $14.6 \%$ in Da Nang had heard about the issuance of these legal documents that mandate the provision of health care for GBV victims.

Data from the IDIs confirm that regardless knowledge on Law on DV, many HCPs consider rape as a serious crime. One female respondent said, "I don't know precisely, but I know raping adolescents is a crime." A male respondent said, "I don't know in depth, but I think in Vietnamese legislation, rape is a severe crime. A few days ago, I read about it in a newspaper and it seems that it is a crime punishable by the death penalty. I don't know which article stipulates this law." Some people know about laws from particular incidents they have heard about. As one female respondent said, "Two guys who raped a girl [treated in my hospital] were sentenced by the court from 5 to 10 years "imprisonment."

It is not compulsory for HCPs to know every detail of the laws, as law enforcement officers must. But it is necessary for them to have basic understanding of the laws in order to provide advice to patients who are GBV victims or perpetrators, or potential victims or perpetrators. Data from this study confirm the previous GBV study in $\mathrm{Ha}$ Noi that concluded more attention should be paid to this issue during training and project implementation. 


\subsubsection{Experience of Health Care Providers} Working with GBV Victims

Experience is defined as direct experience or getting stories from friends and colleagues about DV case detection, treatment, and counselling. A total of $83 \%$ of respondents in both locations had experienced a contact with female DV victims. In the past two years, the proportions were $73.3 \%$ in Da Nang and $67.5 \%$ in HCMC.

\subsubsection{Identification of GBV cases among patients}

HCPs indicated that they detect violence victims amongst their patients based on direct observation, and by speaking with patients and their relatives. Sometimes patients or their relatives describe the experiences openly. The following data describes methods of identifying victims of DV as used by the HCPs in the study who had ever had contact with such patients (83\% in Da Nang and $82.5 \%$ in HCMC).
As shown in Figure 3.9, in both study locations, approximately $50 \%$ of the HCPs said that they had identified DV victims by directly asking patients. Many HCPs also had the experience of the patient telling them directly about the problem $160.5 \%$ in Da Nang and $53.3 \%$ in $\mathrm{HCMC}$ ), or the relatives telling them $142.5 \%$ in Da Nang and $29.1 \%$ in $\mathrm{HCMC}$ ).

In Da Nang, detection of DV victims did not differ greatly by gender of the HCP respondent. Findings showed that $31.3 \%$ of female and $26.5 \%$ of male HCPs have detected violence victims by wounds. Meanwhile, $54.2 \%$ of female and $50 \%$ of male HCPs have asked patients if they are victims of violence. In HCMC, the proportions of female HCPs who have detected DV victims by various methods is consistently lower than among male HCPs (seeing wounds, $27.4 \%$ versus $44.2 \%$; asking patients, $49.2 \%$ versus $55.8 \%$; patients tell, $58.1 \%$ versus $67.4 \%$; patient's relatives tell, $39.5 \%$ versus $51.2 \%$ )

\section{Figure 3.9. How HCPs have detected victims of violence among patients (\%)}

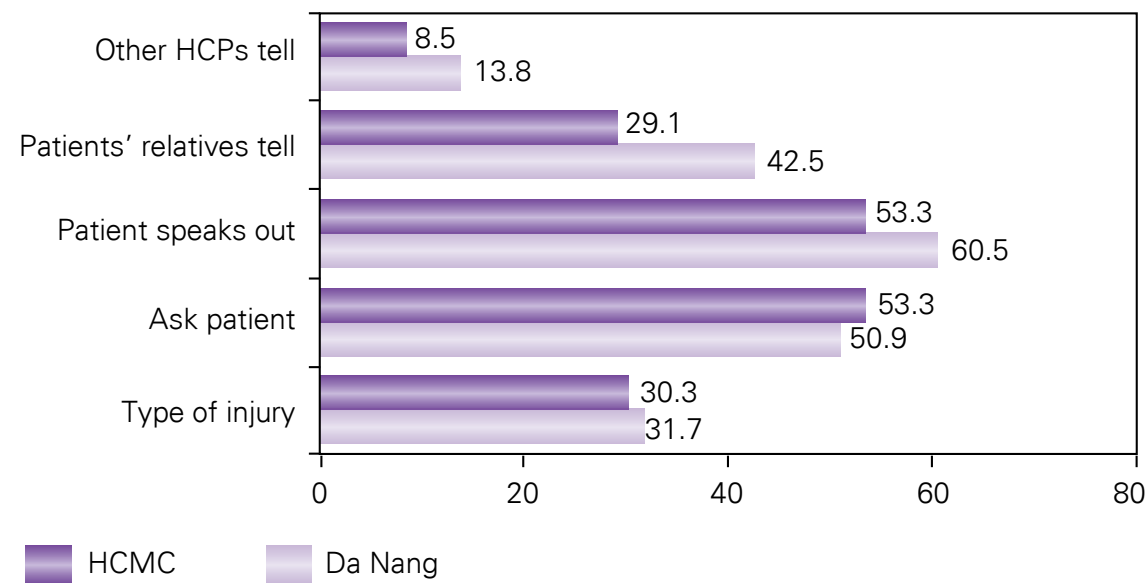

FGDs and individual IDIs shared different ways of detecting GBV cases. Some HCPs ask patients about GBV possibility before giving treatment. As one male respondent said, "My principle is to ask patients about their situation in order to identify the exact position of injuries, what objects caused the injuries, and to determine the severity of injuries." As described by one female respondent, 
skills and experience are required: "First, you need good medical eyesight so that you can differentiate wounds caused by accident or by beating. When you know that it is by beating, you can open communication by saying, 'Well, I think your wound is caused by being beaten. If you tell me, I could help in treatment.' Or, 'By checking, we can see that the wounds seem serious not only outside but also inside. It's fortunate that we have discovered this early or otherwise it could be dangerous. "Patients would be scared and tell you everything. Sometimes, the patient looks very sad and when you ask just one question, she started to cry and tell you her story. So, the skills of HCPs are very important."

Other HCPs treat first and investigate causes later. As one male respondent described, "we cure the injury first and deal with causes later. When I asked why she was injured, she told me other things. She might not tell you on the first time, but she will if you try a second or third time." As a female FGD participant said, "When patients come, you should provide first aid. After that, you can talk about it and give advice. Get them familiar with you first, do not ask about their violence experience right away." Similarly, a male FGD respondent said, "Sometimes [the victims] are not in the mood to speak, but after treatment, they resume balance and are in a better mood. Then we can ask and they will probably tell."

The types of violence experienced by patients of HCP respondents include beating and kicking, even in pregnancy, scolding and insulting (verbal abuse), rape, and neglect among others (Figure 3.10). The proportions varied somewhat by study location, with higher proportions reporting all forms in Da Nang city, except for rape which was more commonly mentioned by respondents in HCMC $(35.2 \%$ versus $29.3 \%$ in Da Nang).

\section{Figure 3.10. Types of domestic violence experienced by patients of HCP respondents (\% answering "Yes")}

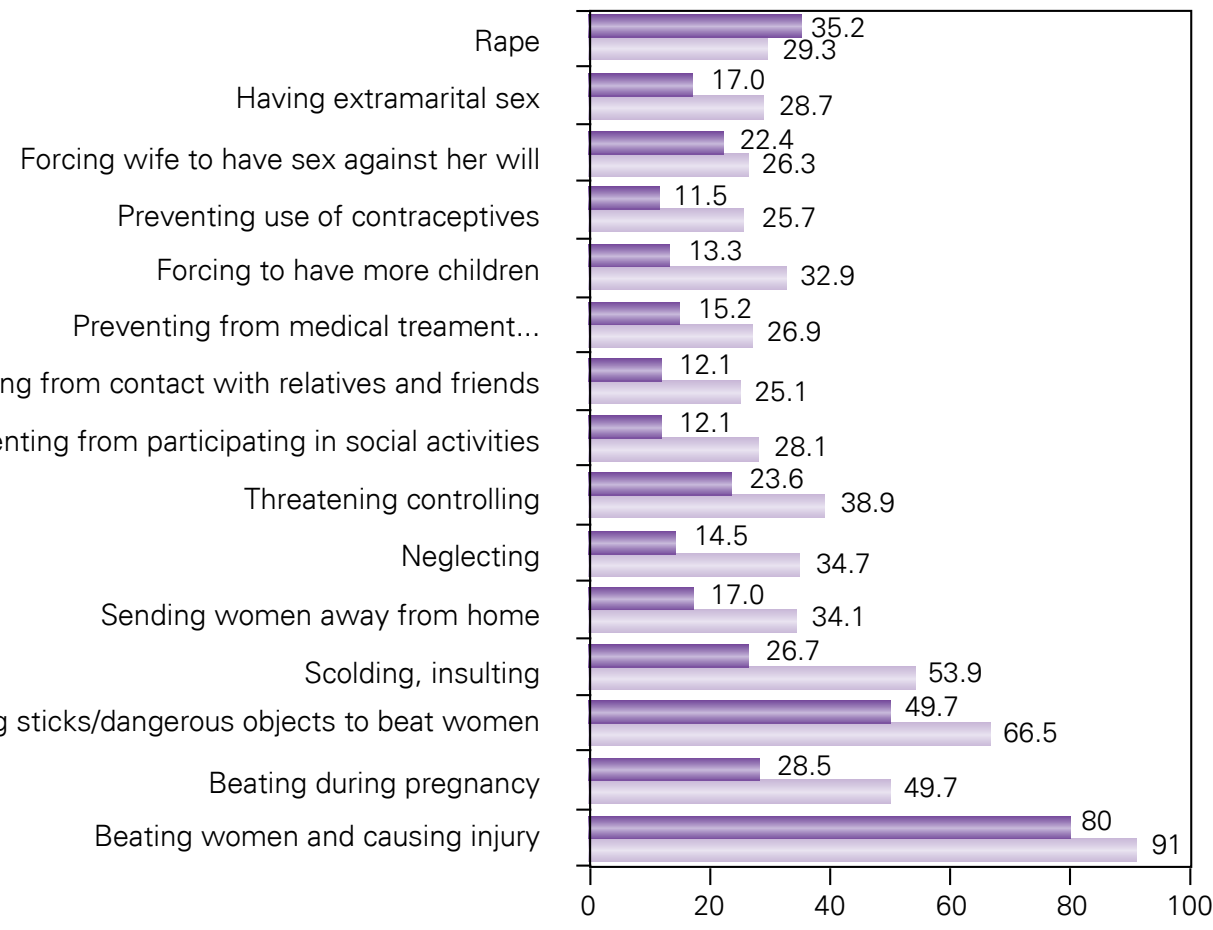

$\operatorname{HCMC}(n=165)$

Da Nang $(n=167)$ 
The types of injuries caused by DV reportedly included:

1) physical wounds $(88 \%$ in Da Nang; 84.8\% in $\mathrm{HCMC}$ ),

2) broken legs or arms (35.9\%; $13.9 \%)$,

3) dangerous injuries, such as to the head or chest $(52.7 \%$; $23.6 \%)$,

4) miscarriage $(19.8 \% ; 12.1 \%)$,

5) injury in sexual organs $(27.5 \%$; $24.8 \%)$, and

6) psychological trauma/tension/stress/ illness $(75.4 \%$; 54.5\%).
3.2.3.2. Experience of providing services for victims of violence

\section{Examination and treatment}

HCPs play the role of identifying, assessing, and providing treatment for injuries and trauma. Besides medical treatment, HCPs can provide counselling and support.

In this survey, $54.3 \%$ of respondents in Da Nang and $61.5 \%$ in HCMC have directly examined GBV patients, and almost $90 \%$ of respondents in Da Nang and $75.6 \%$ in HCMC have directly asked patients whether wounds were caused by violence (Figure 3.11).

\section{Figure 3.11. HCPs who have directly examined GBV patients, and asked patients whether wounds were caused by violence (\%)}

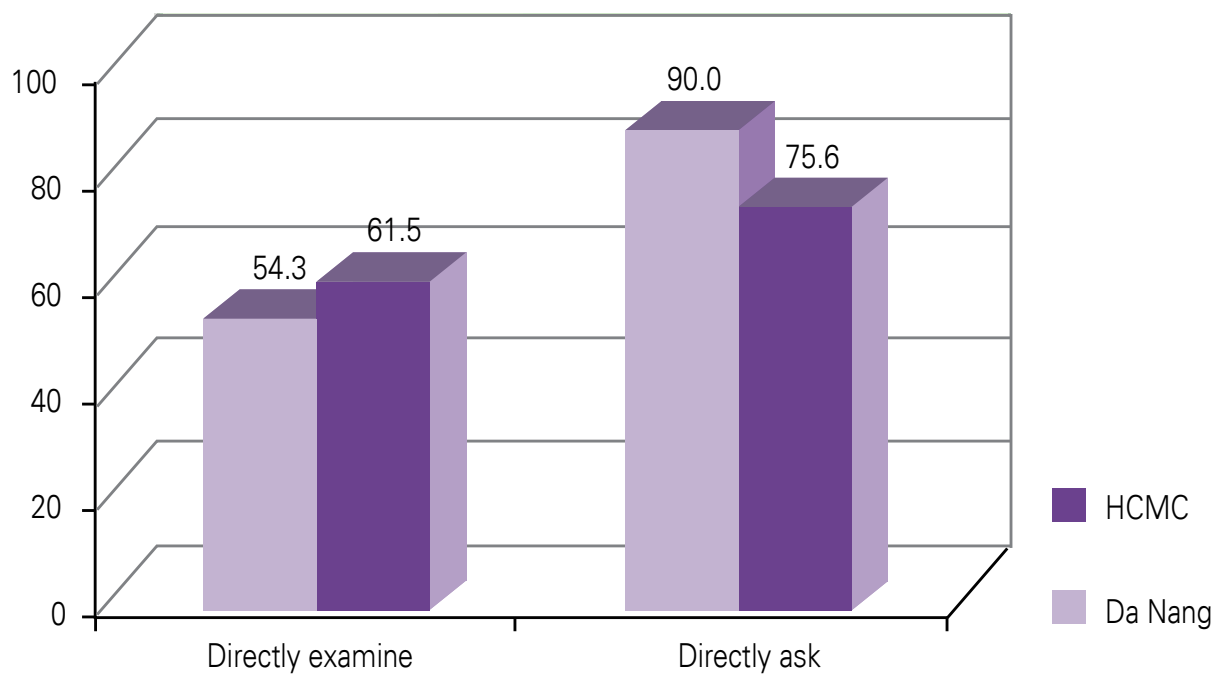

Results showed that the number of HCPs at the two hospitals in HCMC who had asked a patient directly about their DV experience is smaller than at the hospitals in Da Nang. This is despite the fact that the number of HCPs in the study sample working in positions providing treatment to GBV victims in $\mathrm{HCMC}$ is higher than in $\mathrm{Da}$ Nang. A male respondentat Da Nang hospital said that he found out a pregnant mother was beaten by her husband by asking, "... please describe the circumstances of how you got such wounds."
The reasons why a number of HCPs may examine patients without asking for information whether the patient is a GBV victim include: lack of time $19.1 \%$ in $\mathrm{Da}$ Nang; $16.7 \%$ in $\mathrm{HCMC})$; uncomfortable to ask $(18.2 \% ; 6.7 \%)$; consider it a private matter for the patient $19.1 \%$; $36.7 \%)$; afraid to embarrass the patient $(27.3 \%$; $23.3 \%)$; focus on medical treatment $(36.4 \% ; 36.7 \%)$; not part of job requirements from Ministry of Health $(9.1 \% ; 3.3 \%)$. 
The same reasons were also described by respondents in the FGDs and IDIs. As a male FGD participant said, "I really don't have enough time to take care of them. The hospitals receive a lot of patients." In the FGD, a male FGD respondent said, "In fact, it appears absurd to ask patients about GBV when they come just for an examination. I will ask only if I see or hear that the patient has suspicious symptoms. It's up to them whether or not to tell us their story."

Amongst the HCPs who ask directly questions on GBV, 43.4\% in Da Nang and $23.7 \%$ in $\mathrm{HCMC}$ tend to ask at initial patient visits, while $39.4 \%$ in Da Nang and $10.8 \%$ in $\mathrm{HCMC}$ ask frequently during other examinations. The proportion of HCPs who regularly ask about the cause of injuries is approximately $30 \%$ in both study locations. Very few HCPs $13.2 \%$ in $\mathrm{HCMC}$ and $5.1 \%$ in Da Nang) regularly ask questions about DV during a prenatal checkup (Figure 3.12). This means most have never asked patients about DV during a prenatal check-up (92.5\% in HCMC, 89.9\% in Da Nang). Evidently a large number of obstetricians seldom or never ask about possible DV during regular examinations or prenatal check-ups, representing a missed opportunity to identify and assist victims or potential victims of GBV.

\section{Figure 3.12. HCPs who regularly screen patients for GBV in different situations (\%)}

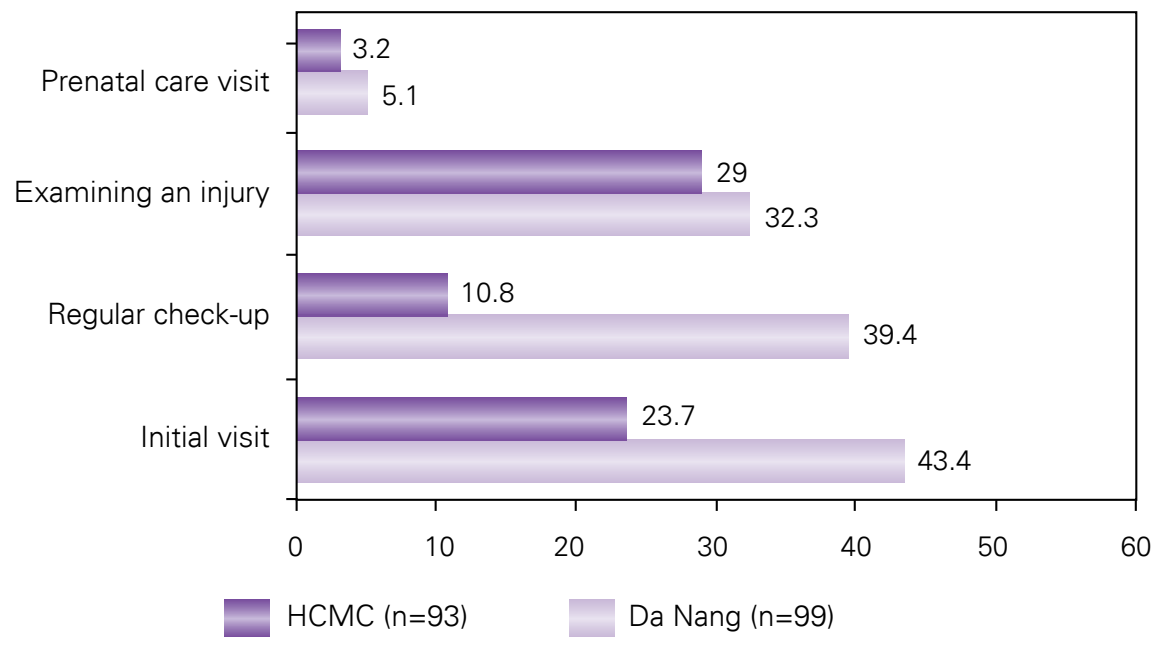

\section{Medical care and spiritual support for victims of $\mathrm{GBV}$}

It was found that among all the HCPs who directly examine violence victims, 78\% in Da Nang and $54.8 \%$ in HCMC provide treatment and spiritual support to the patients. Reportedly, almost all victims are provided treatment in their hospitals, and just a small number are referred to higher-level hospitals. Such referrals are made due to the severity of their conditions $20.2 \%$ in Da Nang; $9.7 \%$ in $\mathrm{HCMC}$ ); lack of forensic examination facilities $(4.6 \% ; 21 \%)$; or lack of adequate equipment for examinations $(2.8 \% ; 4.8 \%)$.
Overall, about three-quarters of respondents $169 \%$ in $\mathrm{HCMC}$; $87.5 \%$ in Da Nang) affirm that HCPs, whether physicians, physician assistants, nurses, or midwives, have the responsibility to help victims. When asked who is responsible for providing support to violence victims beyond medical treatment, $80 \%$ of respondents in Da Nang and $54 \%$ in HCMC affirm that it is the responsibility of physicians, physician assistants, and other HCPs at the hospital. A small number of respondents even mentioned specific treatment and care responsibilities for different HCP types and levels of seniority. 
In the past 2 years, $42.5 \%$ of all $\mathrm{HCPs}$ at the two hospitals in HCMC have examined and given treatment to violence victims. The vast majority of these $(86 \%)$ have examined and treated 1 to 5 violence victims, while $14 \%$ have handled 6 to 10 such patients. In Da Nang, only $26.5 \%$ of HCPs had examined and treated violence victims in the past 2 years. Of those, $75.5 \%$ had served just 1 to 5 such patients, $13.2 \% 6$ to 10 , and the remaining $11.3 \%$ had served 10 or more victims of violence.

Besides medical treatment, HCPs at all four hospitals provide "spiritual" support (more than 90\%), counselling for victims to protect themselves and their children (approximately 20\%), and sometimes other services, including information about other resources, referrals to other centers, and arranging temporary shelter (see Figure 3.13). The proportions of HCPs offering such services at the two study locations did not differ substantially, except that substantially more referrals to counselling centers were reported in HCMC than Da Nang (9.5\% versus 3.0\%). Perhaps there are more counselling and consultation centers for marriage and family issues in $\mathrm{HCMC}$, and/or more HCPs in HCMC with a better understanding of these services.

\section{Figure 3.13. HCPs provision of care and support beyond medical treatment (\%)}

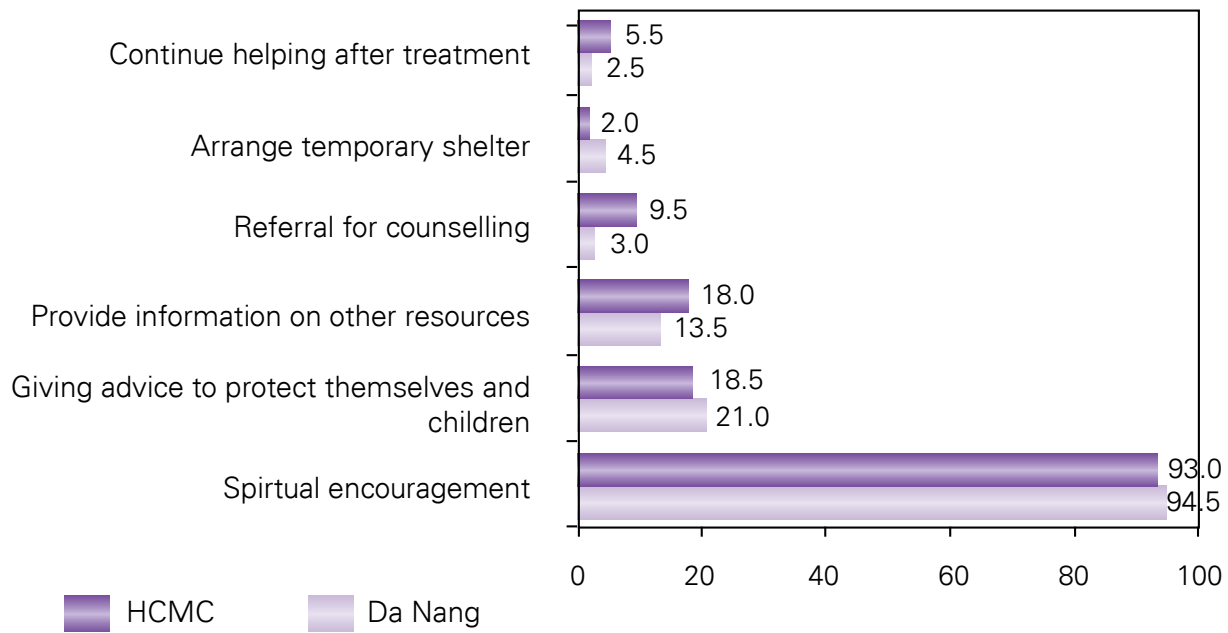

Clearly, there are many HCPs who offer help beyond medical treatment, including sympathy, encouraging words, advice, and counseling. A few have even provided material support for victims in difficulty. As one female respondent at Da Nang hospital said, "The violence victims who go to the hospital will certainly get medical examination and treatment first. Then we provide as much support as we can. Maybe we help them in finding a solution for their family, or suggest they seek help from other sources."

However, findings from IDIs and FGDs indicate that a small number of HCPs just fulfil the minimal obligations of the medical

profession and do not offer any additional support. A female respondent admitted, "... I don't know what I should do to help them. I just give them encouragement." And a male respondent said, "We just give medical treatment. We do not apply psychological treatment. ... We just focus on curing patients. If they don't tell us about their violence incidence, we don't ask or send them to support centers." One FGD respondent said, "They are discharged from hospital right away when the treatment is done. I don't know how to help after medical treatment." These answers reflect HCPs' needs for GBV training on screening and care for violence victims. 
HCPs at the four study hospitals have provided additional support, besides medical treatment, to victims of rape and sexual assault. It should be noted that rape victims go to health facilities or hospital just for preliminary examination, after which they may be sent elsewhere for forensic examination. Depending on their professional positions, HCPs have different roles, including direct treatment and counselling. As one male respondent said, "when I receive patients I will send them to the appropriate department for examination. For instance, sexual assault victims can be sent to the obstetric department. Victims with injuries may be sent to surgery. I work for the internal medicine department."

\section{Coordination amongst relevant agencies in helping victims}

About two-thirds of HCP respondents say they know of institutions and agencies that can help violence victims $170 \%$ in Da Nang; $63 \%$ in HCMC). The Women's Union was most often mentioned in both study locations (by $66.7 \%$ of HCPs in HCMC, $70.7 \%$ in Da Nang). In HCMC, approximately equal proportions of male and female HCPs knew that the Women's Union is active in dealing with cases of violence against women $(67 \%$ of female HCPs, $65.6 \%$ of males). Meanwhile, in Da Nang, it was more often mentioned by male respondents $(75.8 \%$ versus $69.2 \%)$. Counselling centers were only mentioned by $15.0 \%$ of HCPs in $\mathrm{Da}$ Nang, and $11.1 \%$ in HCMC. All other types of assistance agencies were much more often mentioned in Da Nang than in $\mathrm{HCMC}$, including the local government authority $(58.6 \%$ in $\mathrm{Da}$ Nang; $27.8 \%$ in $\mathrm{HCMC}$ ), the Police $(49.3 \% ; 38.1 \%)$, justice departments/courts (29.3\%; $13.5 \%)$, the Youth Union $(22.9 \% ; 7.1 \%)$, and mediation groups $(29.3 \% ; 8.7 \%)$ (see Table 3.2).

Table 3.2. HCPs knowledge of institutions providing support for victims of violence (\%)

\begin{tabular}{|c|c|c|c|c|c|c|}
\hline \multirow{2}{*}{$\begin{array}{l}\text { Institutions } \\
\text { providing } \\
\text { assistance to } \\
\text { violence victims }\end{array}$} & \multicolumn{3}{|c|}{ Da Nang } & \multicolumn{3}{|c|}{ HСMC } \\
\hline & $\begin{array}{l}\text { Have } \\
\text { mentioned }\end{array}$ & $\begin{array}{l}\text { Have not } \\
\text { mentioned }\end{array}$ & $\begin{array}{c}\text { Don't } \\
\text { know/ } \\
\text { No answer }\end{array}$ & \begin{tabular}{c|} 
Have \\
mentioned
\end{tabular} & $\begin{array}{l}\text { Have not } \\
\text { mentioned }\end{array}$ & $\begin{array}{c}\text { Don't } \\
\text { know/ } \\
\text { No answer }\end{array}$ \\
\hline Know any: & 70.0 & & 63.0 & & & \\
\hline \multicolumn{7}{|l|}{ Among which: } \\
\hline Police & 49.3 & 50.7 & - & 38.1 & 61.1 & 0.8 \\
\hline Justice / courts & 29.3 & 70.7 & - & 13.5 & 85.7 & 0.8 \\
\hline Local Authority & 58.6 & 41.4 & - & 27.8 & 71.4 & 0.8 \\
\hline Women's Union & 70.7 & 29.3 & - & 66.7 & 32.5 & 0.8 \\
\hline Youth Union & 22.9 & 77.1 & - & 7.1 & 92.1 & 0.8 \\
\hline Mediation groups & 29.3 & 70.7 & & 8.7 & 90.5 & 0.8 \\
\hline Counseling centers & 15.0 & 85.0 & & 11.1 & 88.1 & 0.8 \\
\hline
\end{tabular}


The opinions expressed during FGDs and IDIs supported the quantitative data. Most respondents did not mention support centers for DV victims. Some HCPs have admitted being completely unaware: "It appears I haven't heard about it" (male interviewee); "There are no such centers" (FGD participant); "I don't know. It is our shortcoming" (female interviewee).

Among those who know of the existence of such organizations, many did not know the name or address. As one female respondent said, "Probably, there are such organisations but I don't know. An organisation which can help GBV women is the Women's Union or department of labour, soldier invalids, and social affairs." And a male respondent said, "I'm a physician but I don't know whether there are such organisations in my locality. I've travelled here and there and I've heard about DV. I think the Women's Union can provide help to violence victims, right? From the level of city to grassroots, we have Women's Unions." Some respondents mentioned knowing an individual or a study supporting violence victims.

\section{Figure 3.14. HCPs working with other agencies to provide assistance to violence victims (\%)}

Note: In Da Nang, 7.5-8.7\% did not know or did not answer

The percentage of health workers affirm having
coordination
Coordination with Police
Local Authority
Women's Union
Justice/Court
Youth Union
Mediation Groups
Counselling Centres

$\operatorname{HCMC}(n=66)$

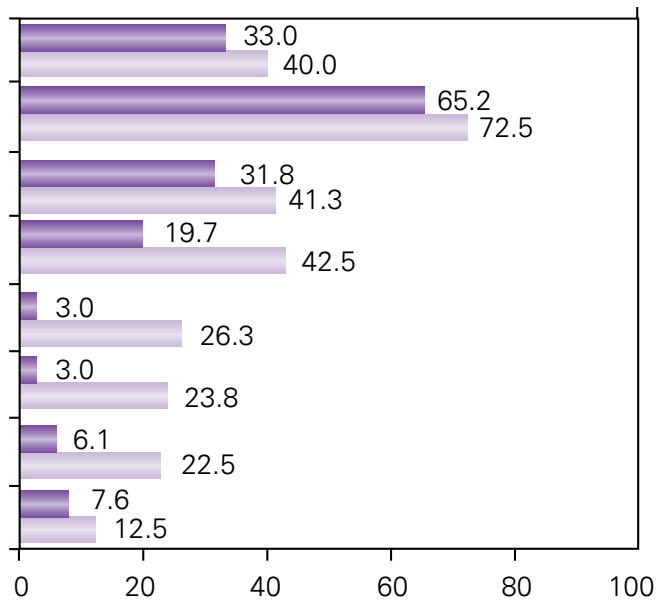

Da Nang $(n=80)$
Only a small number of HCPs knew where to seek help for violence victims, but even these respondents did not have a sense of network of collaborating agencies to assist GBV victims. Only $33 \%$ of $\mathrm{HCPs}$ in HCMC and $40 \%$ in Da Nang stated that they have established collaboration with other agencies; most often with the Police (who carry out forensic examinations), the Local Authority, and the Women's Union (Figure 3.14).

As one male HCP said, the police usually refer victims to relevant agencies for certain procedures, and help HCPs as they fulfil a number of joint duties. A male FGD participant explained, "Some colleagues don't know about procedures of forensic tests. When they request these tests, we know it is a GBV incident. We instruct them to go to police and ask for a letter of forensic request."

DV victims are special patients. Besides treatment for wounds, injuries, and infections caused by violent behaviour, they need support to recover and deal with the physical, psychological, and legal consequences of the incident or pattern of violence. More attention is clearly required for coordination amongst organizations and agencies providing assistance for DV victims. Many HCPs do not 
know the name and addresses of agencies which provide such support. One female respondent said, "Professional organizations for helping GBV victims should be established so that if we receive GBV victim patients, we can refer to them." A male respondent said, "Right now we are not in the right position to refer them [the violence victims] and I don't know any agency to recommend." Another male respondent said, "I haven't recommended any to meet a counsellor. Never." And another said, "I just consoled them, to help mitigate their pain. I haven't recommended patients to counselling or support centers."

The HCPs have helped to treat and comfort their patients, but clearly many HCPs do not know the procedures and how to coordinate with other sectors; the hospitals have yet to issue standard procedures on examining and treating DV victims with an updated list of GBV support and referral agencies. Perhaps those who have worked directly with this group of special patients have more information. Only $5.5 \%$ of HCP respondents in $\mathrm{HCMC}$ and $4 \%$ in Da Nang said that there are standard procedures; while $7 \%$ and $11 \%$, respectively, believed that hospitals maintain a list of relevant GBV referral agencies.

\section{HCPs' awareness and use of GBV service provision guidelines}

In answer to the question "Do you know any guideline documents for HCPs on services for DV at the health facility?" only $8 \%$ of respondents in $\mathrm{HCMC}$ and $14.5 \%$ in Da Nang said "Yes." Among them, 62.5\% (10 out of 16) in HCMC and 62.1\% (18 out of 29) in Da Nang use those guidelines in patient care. Similarly, FGD and IDI respondents said that they had not seen any service provision guidelines, but had heard about the issue in the mass media or from colleagues. A female respondent at Da Nang hospital said, "I've heard about it in the media but never seen any. In the past 2 years, I have not participated in GBV training." A male FGD respondent said, "I know about it vaguely. I haven't read anything. It is mentioned in the media, internet and newspapers."

The $\mathrm{MOH}$ has produced GBV service provision guidelines but many HCPs have not received GBV related training. As one male respondent said, "I haven't read [such documents]. I've just heard in the media about reducing the incidence of violence. It's good for individuals to prevent violence. [I haven't] participated in training on GBV." Another respondent said, "I am too busy. I have not participated in training on gender."

Lacking training or guidelines (treatment protocol), some HCPs have learned how to deal with violence victims by talking with co-workers. As one male FGD respondent explained, "We share experience. I don't know about the documents on treatment for violence victims. We haven't heard about it in our regular meetings."

\section{Figure 3.15. HCPs who know and have used GBV service provision guidelines (\%)}

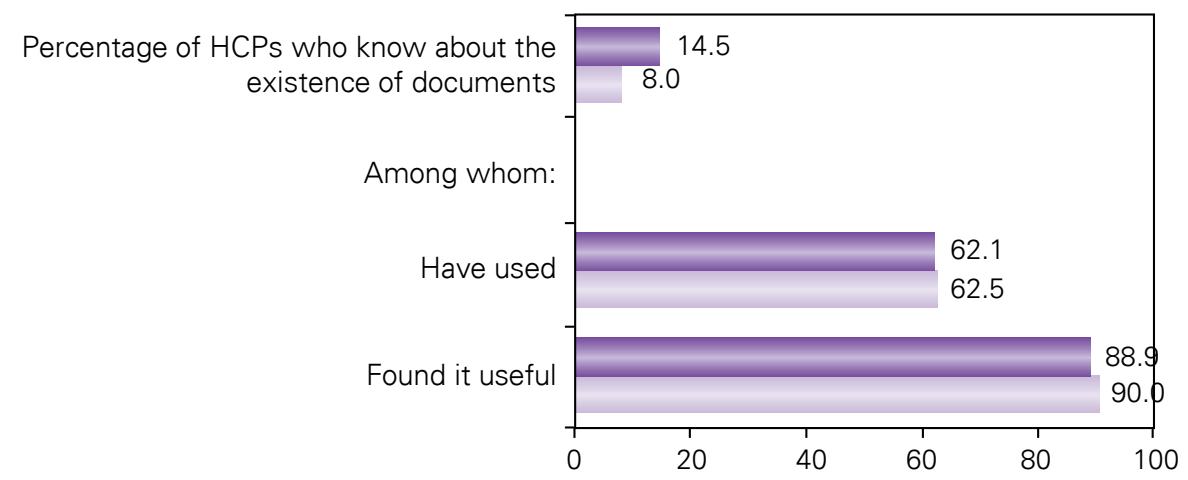

HCMC Da Nang 
For those who have had access to service guidelines or protocols, apparently the information about violence and prevention strategies is useful in treating and assisting patients. Motivated HCPs have sought out the information themselves. As one female respondent said, "Regarding documents I've read, first, the Law on [DV] prevention because it is an official legislation. Secondly, the internet. I read what people are saying about DV. People write about a variety of measures, macro measures and micro measures. For instance, social measures, economic measures, education measures, locally levelled measures, and so on. Those sources are very helpful. I've learnt a lot." A male respondent at the same hospital also said, "I've read them. There are plenty of psychology books which write about what you've mentioned, including rape, sexual coercion. On one hand, it discusses mental issues of the individuals involved. On the other hand, it talks about societies where such kinds of violence occur."
Up to $90 \%$ of respondents who have seen lists of referral centers in HCMC and $88.9 \%$ in $\mathrm{Da}$ Nang affirm that this information has been helpful (Figure 3.15). Source of these lists include the internet, mass media, shared information from coworkers, and other sources like training courses, and conferences. In HCMC, 80\% of the HCPs have read related information in newspapers, $10 \%$ from co-workers, and $10 \%$ from other sources. Men use internet and newspapers for collecting information more than women, while women get information from co-workers and training courses. In Da Nang, 77.8\% of the HCPs who have consulted referral services got the information from the internet and newspapers, $5.6 \%$ from coworkers, and $16.7 \%$ from other sources. As in HCMC, all male respondents use the internet and newspapers, while all female workers learned from co-workers and conferences.

\section{Figure 3.16. HCPs lacking materials to assist with services for violence victims (\%)}

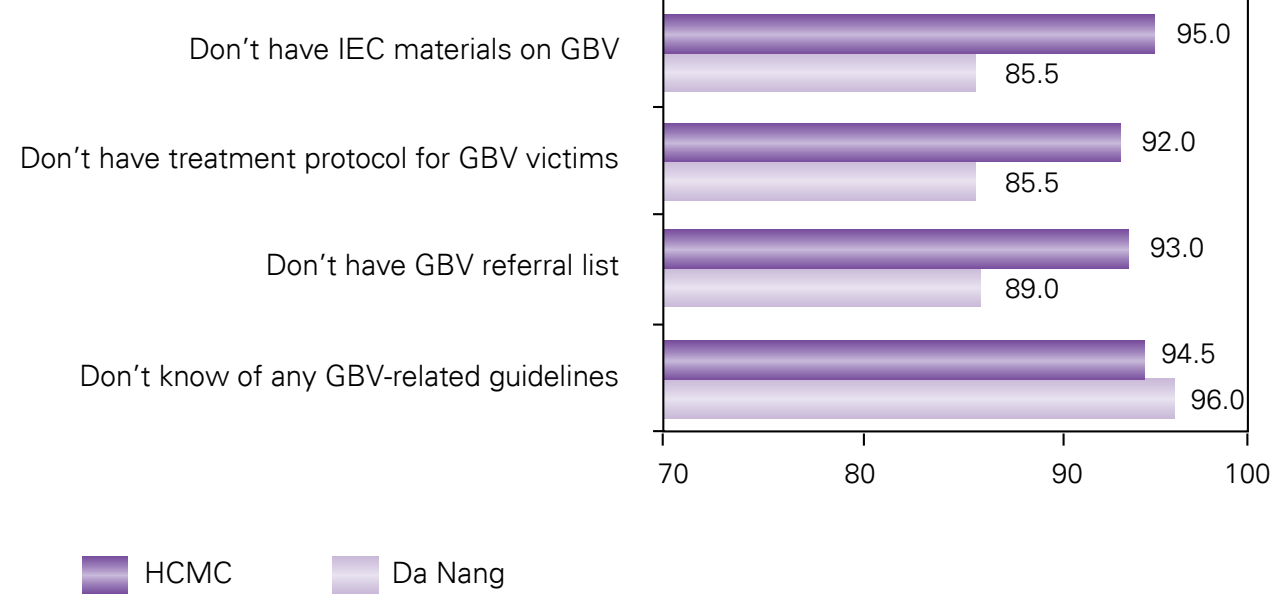


HCPs' awareness and use of GBV information, education, and communication (IEC) materials

Another objective of this study was to determine whether IEC materials about GBV exist in the surveyed hospitals. The results show that only 10 respondents in $\operatorname{HCMC}(5 \%)$, and 29 respondents in $\mathrm{Da}$ Nang (14.5\%) said "Yes," (see Figure 3.16). No leaflets or booklets on GBV were found at the hospitals in HCMC. Only 4 out of 10 respondents say they have seen GBV-related posters at the hospital, and there is no specific treatment record book for violence victims. In Da Nang, only 1 out of 29 respondents say the hospitals keep treatment record books of violence victims; 26 out of 29 respondents have seen related materials like booklets, leaflets; and 5 out of 29 respondents have seen posters on prevention of violence against women in hospitals. Obviously, training is needed with various types of educational and guideline materials. This would help to improve awareness of HCPs, enhance their professional skills and knowledge, including counselling skills, for treatment and support of victims of GBV.

\subsubsection{Strengthening Capacity and Enhancing} Victim Support Services

3.2.4.1. Assessment of resources for treatment and support

Over half of respondents $151 \%$ in $\mathrm{HCMC}$ and $86.5 \%$ in Da Nang) stated that communities should provide resources to support GBV victims. There were no substantial differences between male and female respondents in this. Insufficient resources were mainly perceived as being due to poor awareness $26.3 \%$ of $99 \mathrm{HCPs}$ in $\mathrm{HCMC}$, and $37 \%$ of $27 \mathrm{HCPs}$ in Da Nang). Other causes: shortage of skilled counsellors $132.3 \%$ in HCMC; $14.8 \%$ in Da Nang), weak inter-agency coordination (30.3\%; 29.6\%), weak punishments for GBV crimes $(23.5 \%$; $18.5 \%)$, or lack of financial resources (21.4\%; 18.5\%). However, HCPs doubt that communities have the capacity to provide effective support, due to lack of concern of local authorities and poor inter-agency collaboration at the local level. Views varied by study location (see Table 3.3).

\section{Table 3.3. HCPs' assessments of community resources for violence victims}

\begin{tabular}{|c|c|c|c|c|}
\hline \multirow{3}{*}{$\begin{array}{l}\text { Currently have enough } \\
\text { resources to support violence } \\
\text { victims? }\end{array}$} & \multicolumn{2}{|c|}{ Da Nang } & \multicolumn{2}{|c|}{ HСMC } \\
\hline & Enough & $\begin{array}{c}\text { Not } \\
\text { enough }\end{array}$ & Enough & $\begin{array}{l}\text { Not } \\
\text { enough }\end{array}$ \\
\hline & 86.5 & 13.5 & 51.0 & 49.0 \\
\hline \multicolumn{5}{|l|}{ Not enough because: } \\
\hline $\begin{array}{r}\text { Inadequate awareness of officials at } \\
\text { all levels }\end{array}$ & 37.0 & 63.0 & 26.3 & 73.7 \\
\hline Lack of counselling skills & 14.8 & 85.2 & 32.3 & 67.7 \\
\hline $\begin{array}{r}\text { Lack of coordination amongst } \\
\text { relevant institutions }\end{array}$ & 29.6 & 70.4 & 30.3 & 69.7 \\
\hline $\begin{array}{r}\text { Inappropriate penalty scheme for } \\
\text { perpetrators }\end{array}$ & 18.5 & 81.5 & 23.5 & 76.5 \\
\hline Lack of financial resources & 18.5 & 81.5 & 21.4 & 78.6 \\
\hline
\end{tabular}


Some HCPs were optimistic that local authorities are able to provide supportive services for GBV victims. Those who were pessimistic pointed out that "DV is a private family matter" and this deters officials from making GBV a priority issue. A female respondent said, "I recognize that interventions are given only when the violent behaviour is severe." Many blame the law enforcement officers as irresponsible. A male respondent told "a funny story" about a husband who was beating his wife and somebody reported it to the local police. The policeman asked what was the cause of the beating and then said, 'Let him beat her. We [the police] will deal with him later.' The policeman told the person who reported that if the police come too soon, the beating will not be severe enough for the police to intervene or to apply the Law and confer penalty for the perpetrators. The respondent pointed out that police are interested in dealing with the perpetrators only, but do not care about the prevention of severe injuries that will be suffered by the victims. Also, "... money 'helps' the perpetrator on many occasions because when the perpetrator offers a sum of money, the case is dropped."

Perhaps the local authorities and police have yet to fully engage in violence prevention efforts. When violence incidents are reported, little effort is made to intervene and support the victims. A male respondent said, "Policemen come after the violence has occurred. In the meantime, the Women's Union is neither in the right position nor has adequate knowledge to assist. Thus, all they can do is comfort victims. They don't have skills to give counselling or legal advice." The fact that many victims try to hide their situation by lying about the incident made it more difficult to support GBV victims. Also, often the patients' relatives threatened HCPs to prevent them from intervening in a "private matter."
The HCPs mentioned lack of time to provide support for GBV patients, in all hospitals in the study. As FGD respondents said, "A working day in a polyclinic is so busy and you don't have much time to deal with such matters." "I don't have time ... Many other patients are waiting." The situation is made worse by HCPs' lack of counselling skills. As one male respondent explained, "First, we have to fulfil our duty. Second, HCPs have yet to be equipped with knowledge on dealing with GBV." Many HCPs find it difficult to adequately assist violence victims especially when they lack the counselling skills. One FGD participant said, "[We] have yet to be provided with skills to inquire about the patient's situation. It needs tact as well." And a female FGD respondent said, "I think besides our professional medical treatment, we need to acquire the psychological counselling skills."

Most of the HCPs surveyed were devoted to offer support to GBV victims: $95 \%$ in $\mathrm{HCMC}$ and $97 \%$ in Da Nang. They were keen to give spiritual support $(85.5 \% ; 97.5 \%)$, material support and counselling $(97 \% ; 97.5 \%)$. There were no major differences by gender and almost all $(97 \% ; 97.5 \%)$ agree that HCPs should take responsibility for providing spiritual and social support.

\subsubsection{HCP needs for capacity enhancement}

During the last 2 years, no HCPs have had a GBV-related training. Interest in participating in such training was high, including $93.5 \%$ of HCPs in Da Nang and $95.5 \%$ in $\mathrm{HCMC}$, with no notable differences between male and female HCPs. Among those HCPs, the topics they were interested in varied widely, as shown in Figure 3.17. 


\section{Figure 3.17. GBV-related training needs of HCPs (\%)}

Note: $0.5-5.3 \%$ did not answer or did not know.

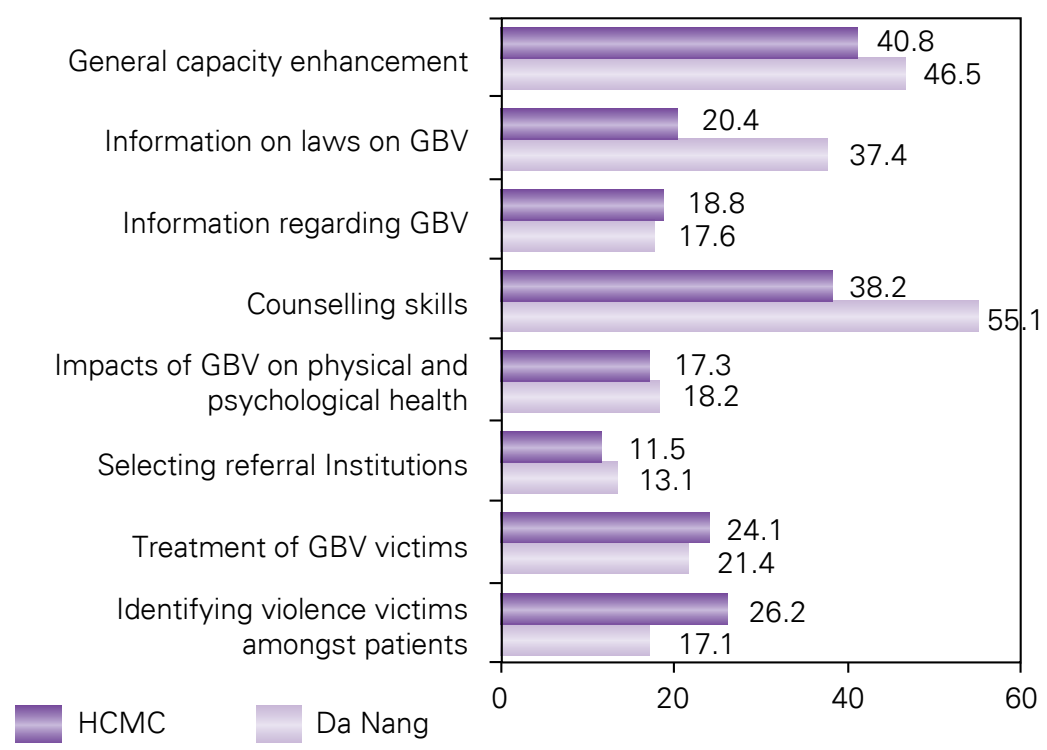

Younger respondents were slightly more likely to express a need and desire for training. Almost $98.1 \%$ of respondents aged 20 to 30 years old in Da Nang and 98.3\% in HCMC expressed the need of training, while the proportion among those aged 40 years and over in the two cities were $92.6 \%$ and $89.1 \%$, respectively. HCPs at the four hospitals were most interested in training on counselling skills, and capacity enhancement in general. Many also expressed interest in relevant legal information, types of violence and types of interventions.

Findings of FGDs and IDIs at the four hospitals also confirmed the need to improve capacity for treatment and support for violence victims. As one female respondent said, "Health care providers should be trained to recognize (screen) GBV victims amongst their patients, and how to manage such special patients." Many respondents say they will participate in training classes which are well organized in terms of time and content. As one female participant said, "I am interested in participating in trainings. As HCPs, we should get more training in the short - or

long-term on the topic of health education and examination skills. Not all HCPs have good methods of examination."

A physician respondent said, "To work well in the health industry, HCPs, especially physicians and nurses who directly treat patients, should learn continuously. Including the skills to screen and prevent GBV behaviour. They should be provided with skills to talk with patients to obtain both health history and violence history. This needs the skills to question patients about their violence experiences..."

The majority of opinions confirm that training is necessary, but the period of training should not be too long, because almost all hospitals have a heavy patient load. A number of respondents expressed the following sentiment: "It is easier for HCPs to take part in short-term training classes, and the information should be concise." The majority of respondents prefer two-day training courses, and receiving the appropriate materials, such as manuals and leaflets. As one FGD participant said, "It is necessary to have a manual with instructions in case of detection, give advice to prevent future violence, and do referrals for victims." 
3.2.4.3. Suggestions for improving quality of care for violence victims

\section{Clear regulations and/or procedures at health facilities:}

The majority of HCPs said that hospitals should have specific standard of procedures for treatment of GBV victims $(82.7 \%$ in $\mathrm{Da}$ Nang; $93.5 \%$ in HCMC). This would clarify the scope of responsibilities and help HCPs apply a standard treatment and support for this special group of patients.

Presently, the screening, treatment and support/referral services provided for GBV victims vary by individual HCP. Besides medical treatment, a substantial proportion of HCPs help victims by giving recommendations for improvements in capacity, working conditions, and other supportive measures that would increase the quality of health care services. It is crucial to the participating HCPs that the safety of victims and their children is a priority. Violence victims must be respected and perpetrators be made to take responsibility for ending their violent behaviour. These HCPs said that to provide support for GBV victims and their children, clear procedures and regulations are needed.

Opinions expressed at FGDs and IDIs support this. A female respondent said, "we now have the regulation that instructs
HCPs to deal with victims when they come to our facilities but I am not sure whether it is necessary to make a report on the patient situation for the police." A male FGD participant said, "It is best to have regulation. We may know the procedures, but we need a regulation to do better." A regulation should bring about a standard procedure that mandates HCPs to improve their counselling skills. A male respondent said, "Ilt would be better] to have a regulation which tells people how to handle violence victims and how to provide them with counselling." Overall, the HCPs emphasized the importance of standard patient care in managing GBV sensitive cases. As one male FGD participant said, standard treatment should include "reduce the pain of patients and give them financial support priority." One female respondent at Da Nang hospital said, "those who experience maltreatment at home should not experience further maltreatment at the hospital. Care and support will help patients recover better."

\section{Public education:}

To reduce and control violence against women, HCPs feel it is necessary to intensify public education programs, especially with men, to increase awareness in communities about gender equality, and to educate women about their rights (Figure 3.18).

\section{Figure 3.18. Recommendations on prevention of violence against women (\%)}

Note: $2.0-6.0 \%$ said it was too hard to answer.

Empower women with information on their rights

Public education on gender equality

Strict penalties to perpetrators

Education for men

Coordination between authorities and community organisations

$\mathrm{HCMC}$

Da Nang

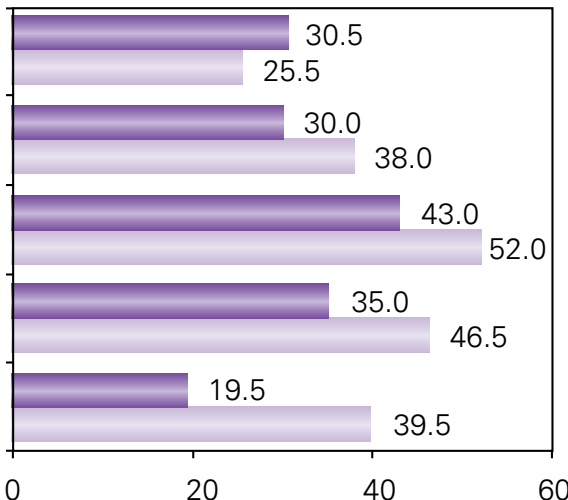

20 
In general, the majority of respondents agree that these legal and educational measures could enhance awareness and change behaviours. HCPs in Da Nang were more likely to recommend each approach than those in HCMC, except for women's rights education and empowerment, which was more often recommended in $\mathrm{HCMC}$. In both regions, female HCPs recommended more measures than males. Additional measures suggested include: intensifying community education programs on violence and prevention of "social evils" (drinking and drugs); education for girls to protect themselves; establishing a hot line; improving household income; and building strong families.

Qualitative data showed a diverse range of opinions on how to prevent family violence. Several respondents suggested community education about the Law, violence prevention, gender equality, and life skills education, especially for young people. One male FGD participant said, "Women should be gentle and skillful to limit violence incidence. We should get on with neighbours but importantly, the wife should be skillful. It is said that the wife should keep silent when her husband gets angry." Another male respondent at Da Nang hospital said, "Husbands should understand whether their acts are right or wrong. Well-educated people have better behaviours."

Communication and education programmes can be carried out in the community or workplace. One male respondent said, "Organisations like the Women's Union, and Youth Union should educate their members. If people have better understanding and gender equality exists, GBV can be reduced." A male FGD participant said that, "[GBV issues] should be taught at schools, from primary school. Siblings in the family beat each other and it constitutes family violence." A female FGD participant said, "The best way is through meetings of people at their residence. Trainings should be carried out at commune level. Commune officials are close to people. GBV education programs should be integrated into other programs of the commune authority." Public education could also use local loudspeakers or other media.

Communication and education programmes should aim to change the belief in male superiority. A male respondent said,"[Education should aim at] men to change their habits of drinking and the belief of male superiority, which considers men as kings and women as subordinate." And for women, education should help them to know their rights. A female FGD participant said, "We should provide women with knowledge so that they can understand their interests and rights. In doing so, women can understand that they are protected by laws." And, that there are regulations and strict penalties for violence perpetrators (Figure 3.18).

\section{Coordination of prevention and care activities:}

HCPs also pointed out the need to have better coordination among concerned institutions and organisations in each locality (Figure 3.18). This requires coordination of many departments at all levels, as detailed by an FGD participant, "Relevant agencies include the Ministry of Health, Ministry of Finance, Ministry of Public Security and organisations like Fatherland Front, Women's Union, Youth Union, Trade Union, Federation of Veterans and Federation of the Elderly. It needs comprehensive efforts... if we pay due attention to the collaboration, we can do it." A female FGD participant stated, "The awareness of the local authority is crucial."

To activate and maintain effective coordination, a taskforce for violence prevention and care activities should be established in localities. As one male respondent said, "In my opinion, we need a shelter for giving counselling and support to GBV victims, operated with the coordination of health and education agencies, under the local authority." 
Economic interventions:

\section{Recommended economic measures include:}

- Increasing compensation for social workers at the local level.

-Adjustment of the hospital fee scheme.

-Hunger eradication and poverty reduction.

Social workers who deal with women's issues, family planning, and mediation at the local level receive a very humble allowance. As one male respondent said, "The allowance is very small, it doesn't encourage people to work. It's tiresome enough just to work and raise children. Nobody wants to do social work for 30,000 VND a month. If the payment is 1 or 2 million VND a month, I think people will be encouraged to do it well."

More broadly, some people believe that hunger eradication and poverty reduction will eradicate violence and other social problems caused by poverty. "If people's living conditions improve, it will reduce [violence]," said a female respondent. "Less unemployment, less social problems," said another female participant.

Therewere suggestions that the hospital fee scheme should be adjusted and GBV victims receive special consideration when it comes to the fees. Violence victims are not covered by medical insurance so they often report it as accidental injury. This causes difficulty for HCPs in managing

\section{PRE- AND POST-TRAINING ASSESSMENTS (TRAINING OF TRAINERS FOR HCPS)}

The Ministry of Health Training of Trainers (TOT) was conducted in July 2010, aiming to provide HCPs with: (a) general knowledge about GBV; (b) the role of HCPs in dealing with GBV victims; (c) indepth knowledge about the Law Domestic such cases. Adjustment of the hospital fee scheme could remove this problem. A female FGD participant said, "We should have a measure to encourage victims to tell the truth from the very beginning. The existing problems with hospital fees make them hide the facts. They must make up a story in order to avoid higher fees. With a better treatment fee scheme, I think, they will be more open with us."

\section{Improved counselling services:}

One suggested measure is to recruit more psychologists to treat violence victims. A male FGD participant suggested, "It would be better to have psychotherapists during treatment." Another FGD participant believed, "Psychologists are well trained to help victims relieve their stress."

Furthermore, it was suggested that hospitals should have a private room or area for provision of counselling and support for GBV victims, who may be traumatised and inclined to hide their situation. A private area can make them more comfortable and encourage them to talk openly. A male respondent said, "Such cases should be provided with a special room that have privacy during history taking. Victims might feel embarrassed if there are other patients in the room. Sometimes, when male physicians examined girls who are victims of rape and sexual abuse, this make girls uncomfortable." A male respondent said, "It is easier to speak with violence victims in a private space where they feel more comfortable to speak out."

Violence Prevention and Control/2007; (d) the National Guidelines for provision of services to GBV victims; and (e) the needed counseling skills. The following are the objectives and methods of the preand post-training assessments. 


\subsection{Objectives}

The objectives of the pre- and post training assessments were:

1) To measure the changes in HCPs' knowledge and perception about GBV in general, in particular about their roles and responsibilities, and preparedness to serve GBV victims;

2) To assess potential as trainers to train other local HCPs in the future and gather recommendations for making future GBV trainings more successful across the country.

\subsection{Methods}

The $\mathrm{MOH}$ selected $55 \mathrm{HCPs}$ to be the potential trainers of future GBV training, 29 from Da Nang and 26 from HCMC. Around $5.5 \%$ came from high administrative level (hospital directors), $38.2 \%$ from clinical departments, and $18.2 \%$ from non-clinical departments. Criteria for the selection include seniority of HCPs, experience in training, clinical exposure to GBV victims, and working in the units involved in planning and organizing future GBV trainings. The training methods included PowerPoint lectures, group discussions, case studies, and role-plays. A self-administered questionnaire with a 1-to-5 rating scale was used to measure changes in the scores obtained before and after the training. Most of the questions were adapted from the GBV-II project questionnaire (Budiharsana and Mai, 2010) with additional materials from the International Planned Parenthood Federation and Western Hemisphere Region questionnaire (IPPF/NHR 2004). The questionnaires consist of:

\section{Pre-training questionnaire contains four sections (see appendix 3):}

Section A: General characteristics of the $\mathrm{HCP}$

Section B: General knowledge and perception about GBV

Section C: Role of HCP (exposure to GBV victims, perception of responsibility, preparedness, knowledge about the Law on DV/2007, and other issues discussed during TOT)

Section D: Previous training on GBV and expected topics to learn during TOT.

\section{Post-training questionnaire contains five sections (see appendix 4):}

Section A: General characteristics of the $\mathrm{HCP}$ (modified to link the post-training with the pre-training questionnaires (i.e., ID, gender, and address of health facilities);

\section{Section B: Similar to pre-training questionnaire \\ Section C: Selected pre-training questions to measure changes in post-TOT}

Section D: Questions on the expected topics to learn in the future

Section E: Feedback regarding training materials, training methods, trainers and further recommendations.

\section{Data collection and management}

Both pre- and post-training TOT questionnaires were pre-tested with a group of HCPs, and an average of 45 minutes time was given to complete the questionnaire.

The pre-training questionnaire was distributed on the first TOT day before the first session (before GBV training materials were distributed). The PCVN team provided information about the objectives of the assessment, began with an introduction about the nature of the study, confidentiality issues, and detailed instruction on how to fill in the questionnaires. Then participants were given 45 minutes to complete the questionnaires. A team member collected the questionnaires immediately after the participants completed their answers. The post-TOT questionnaires were distributed on the last training session, and all participants were given 45 minutes to fill in the questionnaire that had the same ID number as in the pre-TOT questionnaire.

The pre and post-TOT scores were entered into a database designed in Microsoft Access 2007. Data were exported to SPSS 18.0 for further analysis. 


\subsection{Results}

4.3.1. Characteristics of the HCPs in $D_{a}$ Nang and Ho Chi Minh City

A total of 55 HCPs attended the TOT trainings: 29 from Da Nang and 26 from HCMC. The $29 \mathrm{HCPs}$ in Da Nang came from 22 hospitals. This included 2 staff from Da Nang Health Department and 1 staff from The Training Centre under Da Nang Health Department, and 1 staff from the
Centre of Health Education and Promotion. The $26 \mathrm{HCPs}$ in HCMC all came from different hospitals. However, there was no participant from HCMC Health Department. The large majority of participating HCPs (92.7\%) had not attended any GBV training course in the last two years. Table 4.1 shows the distribution of the participants by occupation. The majority of participants were doctors (70.9\%).

\section{Table 4. 1. Distribution of participating HCPs by occupation}

\begin{tabular}{l|c|c|c|c|c|c|c}
\multirow{2}{*}{ Occupation } & \multicolumn{2}{|c|}{ Da Nang } & \multicolumn{2}{c|}{ HCMC } & \multicolumn{2}{c}{ Total } \\
\cline { 2 - 7 } & N & $\%$ & N & $\%$ & N & $\%$ \\
\hline Doctor & 16 & 55.2 & 23 & 88.5 & 39 & 70.9 \\
\hline Assistant doctor & 3 & 10.3 & 0 & 0 & 3 & 5.5 \\
\hline Midwives & 1 & 3.4 & 0 & 0 & 1 & 1.8 \\
\hline Nurse & 6 & 20.7 & 1 & 3.8 & 7 & 12.7 \\
\hline Others & 3 & 10.3 & 2 & 7.7 & 5 & 9.1 \\
\hline Total & $\mathbf{2 9}$ & $\mathbf{1 0 0 . 0}$ & $\mathbf{2 6}$ & $\mathbf{1 0 0 . 0}$ & $\mathbf{5 5}$ & $\mathbf{1 0 0 . 0}$ \\
\hline
\end{tabular}

Table 4.2 shows other characteristics of the participants. As indicated, $38.2 \%$ of the HCPs came from Department of Planning in the hospitals, which is in charge of organizing the future GBV training for the local health staff. $5.5 \%$ came from the hospital Board of Directors, 38.2\% from clinical departments, and $18.2 \%$ from other non-clinical departments. The largest age group were those aged 41 to 50 years, comprising $54.5 \%$ of the sample. An additional $12.7 \%$ were over 50 years old. Very few $(9.1 \%, 5$ staff) were 30 years old or under, including those $(3$ in HCMC and 1 in Da Nang) who had no experience in working with GBV victims. More than $90 \%$ of the HCPs have more than 5 years of service in the health sector, within the range from 11 to 25 years working in the health sector.

\section{Table 4.2. Characteristics of Participating HCPs ( $n=55)$}

\begin{tabular}{c|c|c}
\multicolumn{1}{c|}{ Characteristics } & N & $\%$ \\
\hline Hospital Department & & \\
\hline Clinical Departments & 21 & 38.2 \\
\hline General Planning Department & 21 & 38.2 \\
\hline Board of Directors & 3 & 5.5 \\
\hline Non-Clinical Departments & 10 & 18.2 \\
\hline
\end{tabular}




\begin{tabular}{|c|c|c}
\hline \multicolumn{1}{c|}{ Characteristics } & N & $\%$ \\
\hline Age Group (years) & & \\
\hline$<=30$ & 5 & 9.1 \\
\hline $31-40$ & 13 & 23.6 \\
\hline $41-50$ & 30 & 54.5 \\
\hline$>50$ & 7 & 12.7 \\
\hline Years of Service in Health Sector & 5 & \\
\hline$<=5$ & 6 & 10.9 \\
\hline $6-10$ & 9 & 16.4 \\
\hline $11-15$ & 17 & 30.9 \\
\hline $16-20$ & 12 & 21.8 \\
\hline $21-25$ & 6 & 10.9 \\
\hline$>25$ & & \\
\hline Training Experience & 26 & 47.3 \\
\hline No experience & 6 & 10.9 \\
\hline$<1$ year & 9 & 16.4 \\
\hline 1 to 2 years & 14 & 25.5 \\
\hline$>2$ years & &
\end{tabular}

Before training, the $\mathrm{MOH}$ had sent formal instructions to Da Nang and HCMC Health Department regarding the criteria to select hospital staff to attend the TOT training, preferably senior doctors with experience in working with GBV victims and some experience in conducting training. However, in regards to their experience in training in general, Table 4.2 shows that nearly half of the participants $(47.3 \%)$ had no training experience at all, despite this being one of the selection criteria for the participants. $16.4 \%$ have training experience between 1 to 2 years, and $25.5 \%$ had more than 2 years experience.

It is anticipated that this would limit their capacity in conducting further training for local health staff in the future. The only advantage of this is that the young participants were not as busy as senior staff; therefore, they did fully attend all the TOT sessions. Further discussion with participants revealed that, originally, the hospitals assigned senior staff to attend the GBV TOT workshop; but they said they were too busy and so they were replaced with junior staff.

\subsubsection{Perception and Knowledge of the Health Care Providers on GBV}

Perception of common norms about GBV were measured using a Likert scale, a type of psychometric response scale widely used in survey research. When responding to the questionnaire item, respondents specify their level of agreement to a statement. This study used a traditional five-point scale of 5 levels $(1=$ =Strongly disagree, 2 =Disagree, 3 =Neither agree nor disagree, 4=Agree, $5=$ Strongly agree). The mean scores obtained in pre- and post-training assessments were presented in Table 4.3. All of the mean scores significantly decreased $(p<0.001$, pair t-test) from the pre-training to the posttraining (indicating stronger disagreement), except for the item on the need for external intervention in the case of a husband who frequently beats his wife. 
Table 4.3. Mean score for HCP perceptions of common norms about GBV

\begin{tabular}{|c|c|c|c|c|c|}
\hline No. & Common norms about GBV & $\mathbf{N}$ & $\begin{array}{l}\text { Pre-test } \\
\text { mean } \\
\text { score } \pm \\
\text { SD }\end{array}$ & $\begin{array}{l}\text { Post-test } \\
\text { mean } \\
\text { score } \pm \\
\text { SD }\end{array}$ & $\underset{\text { (pair }}{\text { P }}$ \\
\hline 1 & $\begin{array}{l}\text { The husband should demonstrate to } \\
\text { his spouse that he is the boss in the } \\
\text { family. }\end{array}$ & 54 & $2.79 \pm 1.04$ & $\begin{array}{c}2.08 \pm \\
1.10\end{array}$ & 0.000 \\
\hline 2 & $\begin{array}{l}\text { A good wife should listen to her } \\
\text { husband even if she disagrees with } \\
\text { his opinions or behaviours. }\end{array}$ & 54 & $\begin{array}{c}2.09 \pm \\
0.75\end{array}$ & $\begin{array}{c}1.59 \pm \\
0.59\end{array}$ & 0.000 \\
\hline 3 & $\begin{array}{l}\text { A woman is responsible for } \\
\text { satisfying her husband's sexual } \\
\text { demand even when she doesn't } \\
\text { want to. }\end{array}$ & 54 & $\begin{array}{c}1.92 \pm \\
0.80\end{array}$ & $\begin{array}{l}1.42 \pm \\
0.53\end{array}$ & 0.000 \\
\hline 4 & $\begin{array}{l}\text { Family/domestic conflicts should be } \\
\text { solved within the family. }\end{array}$ & 54 & $\begin{array}{c}3.31 \pm \\
1.00 \\
\end{array}$ & $\begin{array}{l}2.26 \pm \\
0.95 \\
\end{array}$ & 0.000 \\
\hline 5 & $\begin{array}{l}\text { External intervention is needed if a } \\
\text { man frequently beats his wife. }\end{array}$ & 54 & $\begin{array}{l}4.43 \pm \\
0.79 \\
\end{array}$ & $\begin{array}{c}4.15 \pm \\
0.96 \\
\end{array}$ & 0.09 \\
\hline
\end{tabular}

HCPs' perceptions about the husband's right to beat the wife were assessed through six common situations again on a 5-level likert scale as above. For these six items, lower scores (stronger disagreement) indicate opinions more supportive of women's rights not to be beaten in any situation. Generally, the scores for each situation tended to decrease (indicating stronger disagreement) from pre- to posttest (see Table 4.4). However, none of the changes were statistically significant, except regarding the case of an extra marital affair - after the TOT participants average disagreement about a husband's right to beat his wife in this case moved significantly towards strong disagreement $(p=0.006$, pair $-t$ test $)$.

\section{Table 4.4. HCPs' perception about the husband's right to beat the wife}

\begin{tabular}{c|l|c|c|c|c} 
& N & $\begin{array}{c}\text { Pre-test } \\
\text { mean } \\
\text { score } \pm \text { SD }\end{array}$ & $\begin{array}{c}\text { Post test } \\
\text { mean } \\
\text { score } \pm \text { SD }\end{array}$ & $\begin{array}{c}\text { P } \\
\text { (pair t-test) }\end{array}$ \\
\hline $\begin{array}{l}\text { Does not complete housework } \\
\text { and childcare to the standards } \\
\text { expected by her husband }\end{array}$ & 54 & $1.94 \pm 0.87$ & $1.67 \pm 0.70$ & 0.079 \\
\hline 2 & Is addicted to gambling and drugs & 54 & $2.11 \pm 0.94$ & $1.78 \pm 0.86$ & 0.077 \\
\hline 3 & $\begin{array}{l}\text { Contradicts her husband's } \\
\text { opinions }\end{array}$ & 53 & $1.89 \pm 0.80$ & $1.62 \pm 0.68$ & 0.070 \\
\hline 4 & Insults and abuses her spouse & 53 & $2.23 \pm 0.95$ & $1.94 \pm 0.90$ & 0.133 \\
\hline 5 & $\begin{array}{l}\text { Does not satisfy her husband's } \\
\text { sexual demand }\end{array}$ & 54 & $1.74 \pm 0.75$ & $1.63 \pm 0.70$ & 0.401 \\
\hline 6 & Has extra-marital relations & 54 & $2.19 \pm 0.87$ & $1.74 \pm 0.73$ & 0.006 \\
\hline
\end{tabular}


HCPs' perceptions about a woman's right to refuse sex with her husband were assessed through 4 questions, as shown in Table 4.5. Again, answers were recorded on a 5-level Likert scale. A higher score indicates opinions that are more supportive of women's rights and better awareness of GBV issues. The pre-training scores were already above 3.0 (neutral), indicating that in general the HCPs are already supportive of women's rights in this regard. Nevertheless, their scores tended to increase even further after the TOT, with statistically significant increases $(p<0.05)$ for all items except for the opinion on women's rights to refuse sex with her husband when he is drunk $(p=0.054)$, which did not quite reach significance.

\section{Table 4.5. HCPs' perception about a woman's right to refuse sex with her husband}

\begin{tabular}{l|l|c|c|c|c} 
& N & $\begin{array}{c}\text { Pre-test } \\
\text { mean } \\
\text { score } \pm \text { SD }\end{array}$ & $\begin{array}{c}\text { Post-test } \\
\text { mean } \\
\text { score } \pm \text { SD }\end{array}$ & $\begin{array}{c}\text { P } \\
\text { (pair t-test) }\end{array}$ \\
\hline 1 & $\begin{array}{l}\text { She does not want to (without } \\
\text { specific reasons) }\end{array}$ & 54 & $3.20 \pm 0.93$ & $3.87 \pm 0.89$ & 0.000 \\
\hline 2 & She is tired & 54 & $3.85 \pm 0.89$ & $4.31 \pm 0.74$ & 0.008 \\
\hline 3 & Her husband is drunk & 54 & $3.87 \pm 1.19$ & $4.30 \pm 0.83$ & 0.054 \\
\hline 4 & $\begin{array}{l}\text { Her husband treats her } \\
\text { violently }\end{array}$ & 54 & $3.93 \pm 1.41$ & $4.48 \pm 0.84$ & 0.021 \\
\hline
\end{tabular}

HCPs' were asked their opinions on specific behaviours within three categories of GBV: physical, psychological, and sexual violence. They were asked to say, on a 5 -point Likert scale (strongly agree $=5$ ), how strongly they agree or disagree that these behaviours are acceptable in any circumstances. All of the listed behaviours are illegal under the Law on DV, although the HCPs may or may not be aware of that fact. The results are presented in Table 4.6. In this case, lower mean scores indicate higher sensitivity to GBV issues and women's rights (i.e., $1=$ strongly disagree that this behaviour is acceptable in any circumstances). The mean scores were low at the pre-test, indicating disagreement, but also tended to decrease further after TOT training. Statistical significant reduction in scores was achieved on two statements: "abandon a woman due to her workload or poor health" $(p<0.001$, pair $t$ test) and "prevent a woman from participating in social activities" ( $p=0.038)$. 
Table 4.6. HCPs' opinions about the acceptability of specific behaviours (1 =strongly disagree; 5 =strongly agree)

\begin{tabular}{l|c|c|c|c}
\hline $\begin{array}{l}\text { I believe that this behaviour is } \\
\text { acceptable.. }\end{array}$ & N & $\begin{array}{c}\text { Pre-TOT } \\
\text { Mean } \\
\text { score } \pm \text { SD }\end{array}$ & $\begin{array}{c}\text { Post-TOT } \\
\text { Mean } \\
\text { score } \pm \text { SD }\end{array}$ & P \\
\hline Type of violence & & & & \\
\hline Physical violence & & & & \\
\hline Assault and hurt a woman & 54 & $1.46 \pm 0.57$ & $1.28 \pm 0.65$ & 0.142 \\
\hline Beat a pregnant woman & 54 & $1.11 \pm 0.37$ & $1.13 \pm 0.58$ & 0.844 \\
\hline $\begin{array}{l}\text { Use dangerous tools to attack a woman } \\
\text { Psychological violence }\end{array}$ & 54 & $1.09 \pm 0.35$ & $1.15 \pm 0.59$ & 0.553 \\
\hline $\begin{array}{l}\text { Insult, verbally abuse, and publicly } \\
\text { humiliate a woman }\end{array}$ & 54 & $1.41 \pm 0.56$ & $1.28 \pm 0.65$ & 0.278 \\
\hline Throw a woman out of home & 54 & $1.43 \pm 0.63$ & $1.26 \pm 0.67$ & 0.182 \\
\hline $\begin{array}{l}\text { Abandon a woman due to her workload } \\
\text { or poor health }\end{array}$ & 54 & $1.72 \pm 0.59$ & $1.30 \pm 0.66$ & 0.000 \\
\hline Threatening, domineering & 54 & $1.26 \pm 0.48$ & $1.17 \pm 0.60$ & 0.374 \\
\hline $\begin{array}{l}\text { Prevent a woman from participating in } \\
\text { social activities }\end{array}$ & 54 & $1.78 \pm 0.57$ & $1.48 \pm 0.74$ & 0.038 \\
\hline $\begin{array}{l}\text { Prevent a woman from connecting to } \\
\text { family/friends }\end{array}$ & 53 & $1.66 \pm 0.67$ & $1.45 \pm 0.74$ & 0.161 \\
\hline $\begin{array}{l}\text { Prevent a woman from seeking health } \\
\text { care when sick }\end{array}$ & 54 & $1.24 \pm 0.47$ & $1.19 \pm 0.61$ & 0.595 \\
\hline $\begin{array}{l}\text { Accuse a woman of having an } \\
\text { extramarital affair }\end{array}$ & 54 & $1.46 \pm 0.54$ & $1.29 \pm 0.69$ & 0.162 \\
\hline $\begin{array}{l}\text { Sexual violence } \\
\text { Forcing a woman to have more babies }\end{array}$ & 54 & $1.63 \pm 0.68$ & $1.37 \pm 0.68$ & 0.056 \\
\hline $\begin{array}{l}\text { Preventing a woman from using } \\
\text { relations against her will }\end{array}$ & 54 & $1.72 \pm 0.68$ & $1.37 \pm 0.70$ & 0.014 \\
\hline
\end{tabular}

4.3.3. Roles, responsibilities and preparedness of health care providers in dealing with GBV victims

Table 4.7 shows data about how HCPs have in the past identified GBV problems among their patients. As shown, 80\% had asked patients prompted by seeing signs of physical violence, almost threequarters had asked patients if they showed psychological effects indicative of suffering violence or abuse, and about half of the HCPs had asked about violence if there were signs of related economic issues. Almost $55 \%$ said they routinely ask about GBV. 
Table 4.7. Percentage of HCPs who asked about violence when there is a sign of violence in the past

\begin{tabular}{l|c|c|c|c|c}
$\begin{array}{l}\text { Asking about violence if } \\
\text { there is }\end{array}$ & $\mathbf{N}$ & $\begin{array}{c}\text { Yes } \\
(\mathbf{\%})\end{array}$ & $\begin{array}{c}\text { No } \\
(\mathbf{\%})\end{array}$ & $\begin{array}{c}\text { Not applicable } \\
(\mathbf{\%})\end{array}$ & Total \\
\hline Signs of physical violence & 55 & 80.0 & 3.6 & 16.4 & 100 \\
\hline Signs of psychosocial violence & 55 & 72.7 & 9.1 & 18.2 & 100 \\
\hline Signs of economic violence & 55 & 52.7 & 27.3 & 20.0 & 100 \\
\hline Asks about the GBV routinely & 55 & 54.5 & 25.5 & 20.0 & 100 \\
\hline
\end{tabular}

Table 4.8 details HCPs' views about barriers to effectively serving GBV victims at the hospital. HCPs were asked to respond on a 4-point Likert scale about specific potential barriers $(1=$ not a barrier at all; $2=$ a minor barrier; $3=$ a moderate barrier; $4=$ a major barrier), such that a higher mean score indicates more likely to be perceived as a real barrier. As shown, the difference in mean scores between pre- and post-TOT assessments was statistically significant on items: "I could provoke retaliation from abuser" (reduced score, $p=0.001$ ); "I have not received enough trainings to address the issues of violence (reduced score, $\mathrm{p}<0.001) ; "$ "There are few resource in the community where I could refer GBV victims" (reduced score, $p=0.027$ ), and "There is lack of private space in the clinic" (increased score, $\mathrm{p}=0.034$ ).

Table 4.8. Perceived barriers to HCPs effectively serving GBV victims

\begin{tabular}{l|l|c|c|c|c} 
& Barriers & N & $\begin{array}{c}\text { Pre-test } \\
\text { mean } \\
\text { score } \pm \text { SD }\end{array}$ & $\begin{array}{c}\text { Post test } \\
\text { mean } \\
\text { score } \pm \text { SD }\end{array}$ & $\begin{array}{c}\text { P } \\
\text { (pair } \\
\text { t-test) }\end{array}$ \\
\hline 1 & I have time limitations & 53 & $2.68 \pm 1.14$ & $2.68 \pm 0.95$ & 1.000 \\
\hline 2 & $\begin{array}{l}\text { There is lack of private space in } \\
\text { the clinic }\end{array}$ & 54 & $2.50 \pm 1.12$ & $2.93 \pm 1.04$ & 0.034 \\
\hline 3 & $\begin{array}{l}\text { There are few opportunities to } \\
\text { speak with women on one to one } \\
\text { basis }\end{array}$ & 53 & $2.43 \pm 0.99$ & $2.42 \pm 0.90$ & 0.919 \\
\hline 4 & $\begin{array}{l}\text { I feel there is little I can do to help } \\
\text { them }\end{array}$ & 53 & $2.51 \pm 1.15$ & $2.28 \pm 0.96$ & 0.297 \\
\hline 5 & $\begin{array}{l}\text { There are few resources in the } \\
\text { community where I could refer } \\
\text { GBV victims }\end{array}$ & 52 & $3.33 \pm 0.92$ & $2.87 \pm 1.01$ & 0.027 \\
\hline 6 & $\begin{array}{l}\text { I could offend women if I ask } \\
\text { them directly about GBV }\end{array}$ & 53 & $2.17 \pm 1.06$ & $1.96 \pm 0.87$ & 0.287 \\
\hline 7 & $\begin{array}{l}\text { Differences in culture beliefs and } \\
\text { values make it difficult to ask } \\
\text { about violence }\end{array}$ & 53 & $2.06 \pm 1.08$ & $1.89 \pm 0.97$ & 0.366 \\
\hline
\end{tabular}




\begin{tabular}{l|l|l|l|l|c}
\hline Barriers & N & $\begin{array}{c}\text { Pre-test } \\
\text { mean } \\
\text { score } \pm \text { SD }\end{array}$ & $\begin{array}{c}\text { Post test } \\
\text { mean } \\
\text { score } \pm \text { SD }\end{array}$ & $\begin{array}{c}\text { P } \\
\text { (pair } \\
\text { t-test) }\end{array}$ \\
\hline 8 & $\begin{array}{l}\text { I need to focus my attention on } \\
\text { other health problems that have a } \\
\text { higher priority }\end{array}$ & 54 & $2.15 \pm 1.05$ & $2.07 \pm 0.94$ & 0.674 \\
\hline 9 & $\begin{array}{l}\text { Getting involved in cases of } \\
\text { violence means that I have to } \\
\text { participate in police proceedings }\end{array}$ & 54 & $2.15 \pm 1.08$ & $1.91 \pm 0.91$ & 0.155 \\
\hline 10 & $\begin{array}{l}\text { I could provoke retaliation from } \\
\text { abuser }\end{array}$ & 51 & $3.14 \pm 0.93$ & $2.49 \pm 0.92$ & 0.001 \\
\hline 11 & $\begin{array}{l}\text { I have not received enough } \\
\text { trainings to address the issues of } \\
\text { violence }\end{array}$ & 53 & $3.17 \pm 0.89$ & $2.28 \pm 1.09$ & 0.000 \\
\hline 12 & $\begin{array}{l}\text { There is lack of law and } \\
\text { regulations that I could base on }\end{array}$ & 53 & $2.68 \pm 1.14$ & $2.68 \pm 0.95$ & 1.000 \\
\hline
\end{tabular}

Table 4.9 shows the results when HCPs responded to questions about their responsibilities to ask patients with GBV screening questions, using a 5-point Likert scale from Strongly disagree (1) to Strongly agree (5). A higher score indicates a stronger sense of HCP's responsibility to ask about various forms of GVB. At pre-training, mean scores were already around 4 (agree), and at post-training in all cases they moved closer to 5 (strongly agree), with statistically significant change ( $p<0.001$ in all cases), indicating a strong positive effect of the TOT course on HCPs' sense of professional responsibility in this area.

\section{Table 4.9. Self perception of HCPs' responsibility to ask questions about violence:}

\begin{tabular}{l|l|c|c|c|c} 
& N & $\begin{array}{c}\text { Pre-test } \\
\text { mean } \\
\text { score } \pm \text { SD }\end{array}$ & $\begin{array}{c}\text { Post test } \\
\text { mean } \\
\text { score } \pm \text { SD }\end{array}$ & $\begin{array}{c}\text { P } \\
\text { (pair } \\
\text { t-test) }\end{array}$ \\
\hline 1 & $\begin{array}{l}\text { HCPs have responsibility to ask } \\
\text { about physical violence }\end{array}$ & 54 & $4.02 \pm 0.59$ & $4.41 \pm 0.53$ & $<0.001$ \\
\hline 2 & $\begin{array}{l}\text { HCPs have responsibility to ask } \\
\text { psychological violence }\end{array}$ & 53 & $3.87 \pm 0.62$ & $4.40 \pm 0.53$ & $<0.001$ \\
\hline 3 & $\begin{array}{l}\text { HCPs have responsibility to ask } \\
\text { about sexual violence }\end{array}$ & 54 & $3.65 \pm 0.64$ & $4.39 \pm 0.62$ & $<0.001$ \\
\hline 4 & $\begin{array}{l}\text { HCPs have responsibility to ask } \\
\text { economic violence }\end{array}$ & 43 & $3.23 \pm 0.71$ & $4.35 \pm 0.65$ & $<0.001$ \\
\hline 5 & $\begin{array}{l}\text { HCPs have as much } \\
\text { responsibility to ask about } \\
\text { violence as they do to ask about } \\
\text { other causes of health problems }\end{array}$ & 54 & $3.98 \pm 0.65$ & $4.43 \pm 0.57$ & $<0.001$ \\
\hline
\end{tabular}


HCPs were also asked about sense of preparedness to implement specific tasks required for effective and comprehensive GBV services. For each task listed there were three options to choose: $1=$ Inadequately trained/prepared; 2= Somewhat trained/prepared; and $3=$
Sufficiently trained/prepared. Table 4.10 shows the results by percent of HCPs who answered "1" (not prepared). On average, $54 \%$ to $93 \%$ of HCPs felt inadequately prepared/trained before the training. PostTOT, these proportions dropped significantly to $4 \%$ to $7 \%$, as shown per task.

\section{Table 4.10. HCPs' self perception of preparedness for treating GBV victims}

\begin{tabular}{|c|c|c|c|c|}
\hline \multirow[t]{2}{*}{ No } & \multirow[t]{2}{*}{ Tasks } & \multirow[t]{2}{*}{$\mathbf{N}$} & \multicolumn{2}{|c|}{$\begin{array}{c}\text { \% Response to category } \\
\text { "Not adequately trained } \\
\text { or prepared" }\end{array}$} \\
\hline & & & Before TOT & After TOT \\
\hline 1 & $\begin{array}{l}\text { Talk with women about gender based } \\
\text { violence }\end{array}$ & 55 & 83.6 & 3.7 \\
\hline 2 & Detect cases of physical domestic violence & 55 & 67.3 & 7.4 \\
\hline 3 & Detect cases of psychological violence & 55 & 83.6 & 7.4 \\
\hline 4 & Detect cases of sexual violence & 55 & 80.0 & 3.7 \\
\hline 5 & Detect cases of economic violence & 55 & 92.7 & 5.6 \\
\hline 6 & $\begin{array}{l}\text { Identify clients with a history of sexual } \\
\text { abuse during childhood }\end{array}$ & 55 & 87.3 & 3.7 \\
\hline 7 & $\begin{array}{l}\text { Provide care to victims of gender based } \\
\text { violence }\end{array}$ & 55 & 78.2 & 3.8 \\
\hline 8 & $\begin{array}{l}\text { Assess the level of danger of a woman } \\
\text { living in a violent situation }\end{array}$ & 53 & 73.6 & 7.4 \\
\hline 9 & Help client to create a safety plan & 54 & 87.0 & 3.8 \\
\hline 10 & Document cases of violence & 54 & 81.5 & 5.6 \\
\hline 11 & $\begin{array}{l}\text { Record details about a case of violence in a } \\
\text { clinical history form }\end{array}$ & 53 & 92.5 & 7.4 \\
\hline 12 & Provide information to affected clients & 54 & 71.4 & 3.7 \\
\hline 13 & $\begin{array}{l}\text { Provide referrals to victims of gender based } \\
\text { violence }\end{array}$ & 54 & 68.5 & 3.7 \\
\hline 14 & $\begin{array}{l}\text { Counsel women about emergency } \\
\text { contraception }\end{array}$ & 54 & 53.7 & 7.4 \\
\hline 15 & $\begin{array}{l}\text { Address the reproductive health needs of } \\
\text { women who have suffered sexual violence }\end{array}$ & 54 & 64.8 & 5.6 \\
\hline
\end{tabular}


Table 4.11 shows the responses of HCPs when asked to rate their knowledge about a range of GBV-related topics, using a 5-point Likert scale from no knowledge at all (1) to very knowledgeable (5). Before training, HCPs had low mean scores of around 2 for each item (indicating little knowledge). This material was then covered during the TOT course, and at post-TOT assessment, the mean scores had significantly increased in all of the areas/categories to around 3 or 4 for each item.

\section{Table 4.11. HCPs' knowledge about selected areas of services for GBV victims}

\begin{tabular}{|c|c|c|c|c|c|}
\hline & Knowledge on & $\mathbf{N}$ & $\begin{array}{l}\text { Pre-test } \\
\text { mean } \\
\text { score } \pm \\
\text { SD }\end{array}$ & $\begin{array}{l}\text { Post test } \\
\text { mean } \\
\text { score } \pm \\
\text { SD }\end{array}$ & $\underset{\text { (pair }}{P}$ \\
\hline 1 & $\begin{array}{l}\text { Role of HCP in dealing with GBV } \\
\text { victims }\end{array}$ & 53 & $2.36 \pm 0.92$ & $4.08 \pm 0.73$ & $<0.001$ \\
\hline 2 & $\begin{array}{l}\text { HCP responsibilities under the Law } \\
\text { on Domestic Violence Prevention } \\
\text { and Control (2007) }\end{array}$ & 52 & $2.04 \pm 1.06$ & $4.08 \pm 0.83$ & $<0.001$ \\
\hline 3 & $\begin{array}{l}\text { Procedures to work with GBV } \\
\text { victims }\end{array}$ & 52 & $1.85 \pm 1.09$ & $4.08 \pm 0.76$ & $<0.001$ \\
\hline 4 & $\begin{array}{l}\text { Screening and response of HCPs to } \\
\text { GBV }\end{array}$ & 53 & $1.85 \pm 1.04$ & $4.02 \pm 0.82$ & $<0.001$ \\
\hline 5 & GBV screening protocol & 53 & $1.74 \pm 1.02$ & $3.92 \pm 0.85$ & $<0.001$ \\
\hline 6 & Management of GBV victims & 53 & $2.06 \pm 1.09$ & $4.04 \pm 0.83$ & $<0.001$ \\
\hline 7 & $\begin{array}{l}\text { Providing counselling for GBV } \\
\text { victims }\end{array}$ & 53 & $2.00 \pm 0.98$ & $4.02 \pm 0.93$ & $<0.001$ \\
\hline 8 & Dealing with perpetrator & 52 & $1.60 \pm 1.01$ & $3.35 \pm 1.26$ & $<0.001$ \\
\hline 9 & $\begin{array}{l}\text { Required resources for health care } \\
\text { facility to provide treatment and } \\
\text { support for GBV victims }\end{array}$ & 52 & $1.75 \pm 0.98$ & $3.33 \pm 1.20$ & $<0.001$ \\
\hline 10 & $\begin{array}{l}\text { Information about the setting up of } \\
\text { the counselling centre to support } \\
\text { GBV women at health care facility }\end{array}$ & 50 & $1.56 \pm 0.83$ & $3.10 \pm 1.29$ & $<0.001$ \\
\hline
\end{tabular}

The questionnaire also assessed HCPs' awareness of Viet Nam's Law on Domestic Violence Prevention and Control, and any regulations pertaining to the roles and responsibilities of HCPs in dealing with GBV victims. The percentage of HCPs who are unaware of any Law on GBV in Viet Nam was $33.3 \%$, while $36.4 \%$ were unaware of any related regulations for HCPs (Table 4.12). After training all the participants were aware of the GBV-related Laws and regulations. 
Table 4.12. HCPs' Awareness about GBV related Laws and Regulations

\begin{tabular}{l|c|c}
\multirow{2}{*}{ GBV related issues } & \multicolumn{2}{|c}{$\%$ Unaware } \\
\cline { 2 - 3 } & Pre-TOT & Post-TOT \\
\hline Law related to GBV prevention in Viet Nam & 33.3 & 0 \\
\hline $\begin{array}{l}\text { Regulations on roles and responsibilities of } \\
\text { HCPs in dealing with GBV victims }\end{array}$ & 36.4 & 0 \\
\hline
\end{tabular}

\subsubsection{Resources at the Health Facility}

HCPs were also asked about the situation of GBV related resources at the health facility, including a list of relevant referral agencies (Table 4.13) and laws/regulations/guidelines providing guidance about how to implement

\section{GBV-related services (Table 4.16).}

As shown in Table 4.13, most HCPs said there was no referral list or they did not know if there was one or not, at the facility where they work, while only $13 \%$ said they knew of such a list.

Table 4.13. Availability at health facility of a referral list of GBV support agencies

\begin{tabular}{l|c|c} 
Availability of Referral List & N & $\%$ \\
\hline Yes & 7 & 12.7 \\
\hline No & 33 & 60.0 \\
\hline Don't know & 15 & 27.3 \\
\hline Total & $\mathbf{5 5}$ & $\mathbf{1 0 0 . 0}$ \\
\hline
\end{tabular}

4.3.5. Impact of Training and Feedback for Future Needs

Table 4.14 shows HCPs responses when asked to express their interest in training on specific GBV-related areas. As shown, expressed need and desire for training was much higher before than after the TOT, overall, indicating that the TOT satisfied many of the participants in many areas of training needs. Before the TOT, the topics most in demand were "how to provide services to GBV victims" (89.1\%) and "legal issues" (87.3\%). After the TOT, the topics most in demand for future training were "referral options" (60.0\%) and legal issues $(52.7 \%)$. 
Table 4.14. HCPs' interest in a range of training topics, pre- and post-TOT

\begin{tabular}{c|l|c|c} 
No & \multicolumn{1}{|c|}{ Topics } & $\begin{array}{c}\text { \% Yes to topic } \\
\text { want to be trained } \\
\text { on before TOT } \\
\text { (N=54) } \\
\text { ( }\end{array}$ & $\begin{array}{c}\text { \% Yes to topic } \\
\text { want to be trained } \\
\text { on in the future } \\
\text { after TOT (N=54) }\end{array}$ \\
\hline 2 & $\begin{array}{l}\text { How to ask questions to GBV } \\
\text { victims }\end{array}$ & 80.0 & 21.8 \\
\hline 3 & $\begin{array}{l}\text { How to conduct a clinical } \\
\text { exam }\end{array}$ & 74.5 & 41.8 \\
\hline 4 & $\begin{array}{l}\text { How to provide service to } \\
\text { GBV victim }\end{array}$ & 89.1 & 25.5 \\
\hline 5 & Referral options & 85.5 & 43.6 \\
\hline 6 & Health effects & 69.1 & 60.0 \\
\hline 7 & Legal issues & 87.3 & 21.8 \\
\hline 8 & Other & 1.8 & 52.7 \\
\hline
\end{tabular}

The HCPs were asked to provide feedback about the printed documents, slides, and case studies/group discussions used during the TOT. As shown in Table
4.15, not a single participant rated any of the material as "not useful," and most $(60 \%$ or more) rated them as "very useful."

\section{Table 4.15. HCPs' opinion about the training material}

\begin{tabular}{l|c|c|c|c|c}
\hline Type of material & N & $\begin{array}{c}\text { Not } \\
\text { useful }\end{array}$ & Useful & $\begin{array}{c}\text { Very } \\
\text { useful }\end{array}$ & Total \\
\hline Printed documents & 53 & $0 \%$ & $39.6 \%$ & $60.4 \%$ & $100 \%$ \\
\hline Slide/handout & 51 & $0 \%$ & $37.3 \%$ & $62.7 \%$ & $100 \%$ \\
\hline $\begin{array}{l}\text { Case study and group } \\
\text { discussion }\end{array}$ & 52 & $0 \%$ & $36.5 \%$ & $63.5 \%$ & $100 \%$ \\
\hline
\end{tabular}

Finally, as shown in Table 4.16, after the TOT, $92.2 \%$ of the participants said they were confident of their ability to apply what they had learned in their daily work. Also,
$70.6 \%$ indicated that they were confident of their ability to facilitate future training on the same material for other local HCPs.

Table 4.16. Confidence to apply knowledge from TOT in daily work and future training

\begin{tabular}{l|c|c|c|c|c}
\multicolumn{1}{c|}{ Confidence } & N & Yes & No & Not sure & Total \\
$\begin{array}{l}\text { Confident of ability to apply } \\
\text { the knowledge in daily work }\end{array}$ & 51 & $92.2 \%$ & $2.0 \%$ & $5.8 \%$ & $100 \%$ \\
\hline $\begin{array}{l}\text { Confident of ability to } \\
\text { train others (as training } \\
\text { facilitator) on the material }\end{array}$ & 51 & $70.6 \%$ & $3.9 \%$ & $25.5 \%$ & $100 \%$ \\
\hline
\end{tabular}




\section{CONCLUSIONS AND RECOMMENDATIONS}

\subsection{Conclusions}

The quantitative and qualitative findings of both studies documented in this report provide strong evidence that health care providers (HCPs) from the four hospitals, in two urban areas, have a good basic understanding of what behaviors constitute gender-based violence (GBV), could identify the prevailing societal norms and beliefs related to GBV, and recognized the need for support services and enforcement of the 2007 Law on Domestic Violence (DV) Prevention and Control.

The participating HCPs understood the basic causes and consequences of GBV. The recognized causes include gender inequality, traditional societal norms and beliefs, poverty, low education and thus low awareness, and the effects of alcohol, among others. The consequences of violence in general and DV in particular, are considered serious not only for the victims but also the family, community and broader society. Notably, all forms of violence experienced by the HCPs' patients were reported by more HCPs in Da Nang, except for rape, which was reported by more HCPs in HCMC. The opinions collected in FGDs and in-depth interviews (IDIs) also shed light on the levels and trends of violence in the two locations based on respondents experience in their work.

The study provides information about HCPs' experiences of providing services to violence victims. Depending on their position at the hospital, many participating HCPs have directly treated such patients. Due to lack of guidelines, HCPs do not regularly screen patients for DV. Although the majority of respondents reported asking patients about GBV, mostly they did so only if they had injuries clearly indicative of violence, to confirm the specifics of the injuries. Even in such cases, not all HCPs asked about violence, and many patients would not volunteer a truthful explanation. Opinions varied, and there were conflicting

opinions on some issues, such as the need for treatment protocols for GBV patients, and whether (or at what point) to ask patients directly about violence.

Besides medical treatment, most HCPs at the hospitals reported providing additional support. However, clearly their skills and training were limited; they lack patient management guidelines, counselling skills, and information about (and coordination with) referral agencies for further services. The hospitals in the study had few or no IEC materials nor any public awareness-raising activities aimed at prevention of violence against women.

HCPs gave their views on how to prevent and manage GBV cases in the health care system and in the community. The strengths and weaknesses of institutions and organisations in coordinating services for GBV victims were assessed at different levels. Based on their experience, HCPs suggested comprehensive measures (social, economic, and organisational) and specific recommendations to improve GBV services and capacity of HCPs.

The experiences and opinions of HCPs in each city, and of different genders, vary somewhat. These differences can be used to inform training and project implementation later. The views of HCPs detailed in this report represent an important foundation for project development and implementation in the study locations.

The pre- and post-Training of Trainers (TOT) questionnaire aimed to assess the HCPs on the topics covered in the training course. The results showed that basic knowledge of hospital staff about GBV improved significantly as an immediate result of training. Before the training, 33.3\% of participants were not aware of any Law related to GBV prevention in Viet Nam. $36.4 \%$ were not aware of any regulations 
about the role and responsibility of HCPs in dealing with GBV victims. After training all the participants were aware of the GBV Laws and regulations related to GBV. Hospital staff also acknowledged a greater sense of responsibility and readiness to work with GBV victims post-training. Almost all HCPs (92\%) indicated that they felt confident enough to apply what they learnt from the TOT training in their daily practice, and $72 \%$ said they would feel comfortable using the knowledge and skills obtained from the TOT to train local health staff.

In summary, the TOT training has improved HCPs' knowledge about GBV, GBV-related Laws and regulations, and the role and responsibilities of HCPs in working with GBV victims. More importantly, they have the training materials and sources of information to help them in conducting further training for local HCPs.

\subsection{Recommendations}

Based on the study findings, an intervention programme to improve the quality of health care for violence victims at hospitals should be developed involving the following components and considerations:

\section{Training of HCPs:}

- Content should include comprehensive knowledge on GBV, including types of and causes of violence which occur most often in different localities and situations, and also consequences of violence, including on health. Also, information about legislation pertaining to GBV, including associated penalties, and related services offered by other institutions/referral agencies.

- HCPs should be introduced to the concepts, methods and tools of data collection, and methods for calculation of violence incidence.

- Teach skills needed for screening and counselling violence victims.
- Training should be arranged in short sessions, at feasible times and appropriate locations for HCPs. Training sessions of not more than 2 or 3 days are recommended so that HCPs can fully participate. Also, the training schedule should be confirmed well in advance for HCPs to have enough time to arrange their participation plan.

- Information provision might also be provided through other channels like conferences, meetings with different groups of HCPs and staff.

- Participants forTraining-of-Trainers(TOT) should be carefully selected. Criteria should prioritize HCPs with more training and clinical experience, and include people from the provincial health service and Health Training Centre. This will ensure good coordination in conducting the training at local hospitals.

\section{Facilities, Tools and Data:}

- A private and safe room should be available for provision of counselling and support for violence victims.

- Compile manuals or guidelines for screening, examination, treatment, and referral of violence victims, for use in health facilities, in addition to data collection forms and procedures.

- Compile IEC materials appropriate to different audiences.

- Develop a network of GBV-related institutions and maintain up-to-date lists of referral services in different locations.

\section{Coordination:}

- Hospitals should work closely with other local health facilities, local authority, police, community groups, and treatment referral centres, as well as engaging in community outreach or awareness-raising, to build an effective network and environment for violence prevention and case management. 
- Any one of these areas of improvement will not be effective on its own, but all must be developed in an integrated manner, with involvement of senior hospital staff and HCPs at all levels and in many different departments.
Currently, many caring HCPs seek information independently to help them better serve their patients. But without the support of hospital protocols or a network of referral agencies, their efforts can only go so far. 


\section{REFERENCES}

Budiharsana, Meiwita P. and Mai Quoc Tung. Project Evaluation Report on Improving the Health Care Response to Gender-Based Violence - Phase II. Ha Noi, Viet Nam: Population Council, 2010.

Centre for Reproductive Health and Family (2000). Domestic Violence Against Women: Attitudes and Practices of Health Care Staff for Victims of Domestic Violence Against Women.

Ha VS, Hoang TA, et al. (2009). Domestic Violence in Viet Nam: Situations and Challenges. Health Alert Asia Pacific Newsletter (15).

Heise L., Ellsberg M., Gottmoeller M., A global overview of gender-based violence. International Journal of Gynaecology and Obstetrics 78 Suppl. 1 (2002) S5-S14.

IPPF/WHR (2004). Improving the Health Sector Response to Gender-Based Violence: A Resource Manual for Health Care Professionals in Developing Countries, International Planned Parenthood FederationMestern Hemisphere Region Inc.

Loi, V., VT. Huy, et al. (1999). Genderbased violence: the case of Viet $\mathrm{Nam}$. Ha Noi, World Bank.

Mai, LTP. (1998). Violence and its Consequences for Reproductive Health, the Viet Nam case. South \& East Asia Regional Working Papers. Ha Noi, PCVN. 12.

Mai, LTP. and Landfield K. (1999). Report on an Intervention Project: Developing Counseling Materials on Domestic Violence for the Ho Chi Minh City Hotline. An internal document. Ha Noi, Population Council Viet Nam.

Mai LTP, Lan LN, Thom NT, Tuan $\mathrm{PL}, 2005$, "Findings of the pre and post intervention conducted at health facilities in districts and communes, Ha Noi."

Ministry of Foreign Affairs, General information about Viet Nam. Updated March 2010. Available at: http://www.mofa.gov. vn/en/tt_vietnam/\#Nm6NBh6HUXNn. Accessed 20 August, 2010.
Nguyen, DV, Ostergren PO, et al. (2008). Intimate partner violence against women in rural Viet Nam--different socio-demographic factors are associated with different forms of violence: need for new intervention guidelines? BMC Public Health 8: 55.

Population Council, 2000: Report on an Intervention Project: Training and Developing Counselling Materials on Domestic Violence and Reproductive Health for the Counselling Centre Hotline in $\mathrm{Ha}$ Noi and Ho Chi Minh City.

UNFPA, Viet Nam (2007). Gender Based Violence Programming Review. Ha Noi, UNFPA.

UNICEF, ESCAP, et al. (2001). Report of the East Asia and the Pacific Regional Consultation for the Second World Congress Against Commercial Sexual Exploitation of Children. Bangkok.

UNICEF EAPRO (2005). Report of the Seventh East Asia and Pacific Ministerial Consultation on Children: Siem Reap, Angkor, Cambodia. Bangkok, UNICEF EAPRO.

Viet Nam Country Progress Report (2004). Draft Report for the Conference on monitoring Vietnam's Realization of Yokohama Commitment's Objectives and Plan of Action against Commercial Sexual Exploitation of Children. Post-Yokohama Mid-Term Review of the East Asia and the Pacific Regional Commitment and Action Plan against Commercial Sexual Exploitation of Children. CSEC. Bangkok.

Viet Nam Women's Union. 2001. Domestic Violence on Vietnamese Women: research findings in Thai Binh, Lang Son and Tien Giang provinces. Bạo lực gia đình đối với phụ nữ Việt Nam: kết quả nghiên cứu tại Thái Bình - Lạng Sơn và Tiền Giang.

World Health Organization (WHO) [website]. Violence against women. Fact sheet N0239. November 2009. Available at: $\quad$ http://www.who.int/mediacentre/ factsheets/fs239/en/. Accessed August 20, 2010. 


\section{APPENDICES}

\section{Appendix 1:}

Table A. Knowledge and attitudes of health care providers about gender and GBV

\begin{tabular}{|c|c|c|c|c|c|c|c|c|}
\hline \multirow[b]{2}{*}{ Statements } & \multicolumn{4}{|c|}{ Da Nang } & \multicolumn{4}{|c|}{ HСМс } \\
\hline & Agree & $\begin{array}{l}\text { Dis- } \\
\text { agree }\end{array}$ & $\begin{array}{c}\text { Depends } \\
\text { on } \\
\text { circum- } \\
\text { stances }\end{array}$ & $\begin{array}{l}\text { Hard to } \\
\text { answer }\end{array}$ & Agree & $\begin{array}{l}\text { Dis- } \\
\text { agree }\end{array}$ & $\begin{array}{l}\text { Depends } \\
\text { on } \\
\text { circum- } \\
\text { stances }\end{array}$ & $\begin{array}{l}\text { Hard to } \\
\text { answer }\end{array}$ \\
\hline $\begin{array}{l}\text { A man should } \\
\text { display his } \\
\text { power of } \\
\text { being family } \\
\text { head to his } \\
\text { wife }\end{array}$ & 38.0 & 46.5 & 15.0 & 0.5 & 8.5 & 64.5 & 25.5 & 1.5 \\
\hline $\begin{array}{l}\text { A good wife } \\
\text { must listen to } \\
\text { her husband } \\
\text { even though } \\
\text { she doesn't } \\
\text { agree with } \\
\text { him }\end{array}$ & 9.0 & 80.5 & 9.0 & 1.5 & 4.0 & 79.5 & 16.0 & 0.5 \\
\hline $\begin{array}{l}\text { A woman } \\
\text { must meet } \\
\text { her husband's } \\
\text { sexual needs }\end{array}$ & 9.5 & 80.5 & 8.5 & 1.5 & 5.0 & 83.0 & 9.0 & 3.0 \\
\hline $\begin{array}{l}\text { Family } \\
\text { conflicts must } \\
\text { be settled } \\
\text { within family } \\
\text { setting }\end{array}$ & 67.0 & 8.5 & 24.0 & 0.5 & 66.0 & 6.5 & 26.0 & 1.5 \\
\hline $\begin{array}{l}\text { If a man beats } \\
\text { his wife, the } \\
\text { intervention } \\
\text { of outsiders is } \\
\text { necessary }\end{array}$ & 82.0 & 10.0 & 7.5 & 0.5 & 78.0 & 6.0 & 9.0 & 7.0 \\
\hline
\end{tabular}


Table B. Health care providers' awareness of GBV behaviours

\begin{tabular}{|c|c|c|c|c|c|c|c|c|}
\hline \multirow[b]{2}{*}{ Statements } & \multicolumn{4}{|c|}{ Da Nang } & \multicolumn{4}{|c|}{ НСМс } \\
\hline & Agree & $\begin{array}{l}\text { Dis- } \\
\text { agree }\end{array}$ & $\begin{array}{l}\text { Depends } \\
\text { on } \\
\text { circum- } \\
\text { stances }\end{array}$ & $\begin{array}{l}\text { Hard to } \\
\text { answer }\end{array}$ & Agree & $\begin{array}{l}\text { Dis- } \\
\text { agree }\end{array}$ & $\begin{array}{l}\text { Depends } \\
\text { on } \\
\text { circum- } \\
\text { stances }\end{array}$ & $\begin{array}{l}\text { Hard to } \\
\text { answer }\end{array}$ \\
\hline $\begin{array}{l}\text { A man should } \\
\text { display his } \\
\text { power of being } \\
\text { family head to } \\
\text { his wife }\end{array}$ & 38.0 & 46.5 & 15.0 & 0.5 & 8.5 & 64.5 & 25.5 & 1.5 \\
\hline $\begin{array}{l}\text { A good wife } \\
\text { must listen to } \\
\text { her husband } \\
\text { even though } \\
\text { she doesn't } \\
\text { agree with him }\end{array}$ & 9.0 & 80.5 & 9.0 & 1.5 & 4.0 & 79.5 & 16.0 & 0.5 \\
\hline $\begin{array}{l}\text { A woman } \\
\text { must meet } \\
\text { her husband's } \\
\text { sexual needs }\end{array}$ & 9.5 & 80.5 & 8.5 & 1.5 & 5.0 & 83.0 & 9.0 & 3.0 \\
\hline $\begin{array}{l}\text { Family conflicts } \\
\text { must be settled } \\
\text { within family } \\
\text { setting }\end{array}$ & 67.0 & 8.5 & 24.0 & 0.5 & 66.0 & 6.5 & 26.0 & 1.5 \\
\hline $\begin{array}{l}\text { If a man beats } \\
\text { his wife, the } \\
\text { intervention } \\
\text { of outsiders is } \\
\text { necessary }\end{array}$ & 82.0 & 10.0 & 7.5 & 0.5 & 78.0 & 6.0 & 9.0 & 7.0 \\
\hline
\end{tabular}


Table C . Perceived severity of GBV behaviours

\begin{tabular}{|c|c|c|c|c|c|c|c|c|}
\hline \multirow{2}{*}{ Behaviours } & \multicolumn{4}{|c|}{ Da Nang } & \multicolumn{4}{|c|}{ НСМС } \\
\hline & $\begin{array}{c}\text { Very } \\
\text { serious }\end{array}$ & Serious & $\begin{array}{c}\text { Not } \\
\text { serious }\end{array}$ & $\begin{array}{c}\text { Not } \\
\text { answer }\end{array}$ & $\begin{array}{c}\text { Very } \\
\text { serious }\end{array}$ & Serious & $\begin{array}{c}\text { Not } \\
\text { serious }\end{array}$ & $\begin{array}{c}\text { Not } \\
\text { answer }\end{array}$ \\
\hline $\begin{array}{l}\text { Beating women } \\
\text { causing injury }\end{array}$ & 49.0 & 48.5 & 1.5 & 1.0 & 37.5 & 58.0 & 4.0 & 0.5 \\
\hline $\begin{array}{l}\text { Beating during } \\
\text { pregnancy }\end{array}$ & 93.0 & 7.0 & - & - & 84.5 & 15.5 & - & - \\
\hline $\begin{array}{l}\text { Using sticks/ } \\
\text { dangerous } \\
\text { objects to beat } \\
\text { women }\end{array}$ & 86.0 & 14.0 & - & - & 77.5 & 22.5 & - & - \\
\hline $\begin{array}{l}\text { Scolding, } \\
\text { insulting }\end{array}$ & 26.0 & 64.5 & 7.0 & 2.5 & 20.0 & 49.0 & 8.0 & 23.0 \\
\hline $\begin{array}{l}\text { Sending women } \\
\text { away from home }\end{array}$ & 45.0 & 46.5 & 4.0 & 4.5 & 19.0 & 47.5 & 5.5 & 28.0 \\
\hline Neglecting & 25.1 & 58.3 & 4.5 & 12.1 & 14.0 & 35.0 & 5.0 & 46.0 \\
\hline $\begin{array}{l}\text { Threatening, } \\
\text { controlling }\end{array}$ & 60.0 & 34.0 & 2.0 & 4.0 & 52.5 & 41.0 & 2.5 & 4.0 \\
\hline $\begin{array}{l}\text { Preventing from } \\
\text { participating in } \\
\text { social activities } \\
\text { and studying }\end{array}$ & 13.5 & 58.0 & 8.5 & 20.0 & 4.0 & 36.5 & 10.5 & 49.0 \\
\hline $\begin{array}{l}\text { Preventing } \\
\text { from contacting } \\
\text { relatives and } \\
\text { friends }\end{array}$ & 17.5 & 57.0 & 6.5 & 19.0 & 12.0 & 38.0 & 10.0 & 40.0 \\
\hline $\begin{array}{l}\text { Preventing from } \\
\text { treatment }\end{array}$ & 60.5 & 29.5 & 2.0 & 8.0 & 45.5 & 32.5 & 0.5 & 24.5 \\
\hline $\begin{array}{l}\text { Forcing to have } \\
\text { more children }\end{array}$ & 25.5 & 50.0 & 9.0 & 15.5 & 18.0 & 35.5 & 7.0 & 36.5 \\
\hline $\begin{array}{l}\text { Preventing } \\
\text { from using } \\
\text { contraceptives }\end{array}$ & 14.0 & 57.5 & 7.5 & 21.0 & 16.5 & 33.5 & 10.5 & 39.5 \\
\hline $\begin{array}{l}\text { Forcing to have } \\
\text { sex }\end{array}$ & 27.5 & 57.0 & 4.5 & 11.0 & 26.5 & 43.5 & 9.0 & 21.0 \\
\hline $\begin{array}{l}\text { Having } \\
\text { extramarital sex }\end{array}$ & 41.0 & 27.5 & 2.0 & 29.5 & 33.0 & 16.0 & 3.0 & 48.0 \\
\hline
\end{tabular}


Appendix 2:

1) Population Council

MINISTRY OF HEALTH

FORD FOUNDATION

HA NOI HEALTH DEPARTMENT

\section{IMPROVING QUALITY OF HEALTH CARE FOR GENDER-BASED VIOLENCE VICTIMS AT HEALTH FACILITIES IN VIET NAM}

PRE-INTERVENTION ASSESSMENT

\section{Questionnaire to interview Health Care Providers}

(Round 1)

\begin{tabular}{|l|l|l|}
\hline HOSPITAL & 01 & 02 \\
\hline CITY & 01 & 02 \\
\hline INTERVIEWERS ID & & \\
\hline CHECKING BY & 01 & 02 \\
\hline
\end{tabular}




\section{PROJECT: IMPROVING QUALITY OF HEALTH CARE FOR GENDER-BASED VIOLENCE VICTIMS AT HEALTH FACILITIES IN VIET NAM}

Say to the interviewee: Hello. My name is... I am participating in a pre-intervention assessment on perceptions, knowledge and practical skills of health care providers (HCPs) in receiving, treating and supporting GBV victims through health care services by the Medical Services Administration (MSA)
- $\mathrm{MOH}$ at your health facility. I would like to ask you some questions on this issue. We ensure that the information provided by you will be confidential and your name will not be recorded. You don't have to answer the questions that you don't want to and you can stop at any time.

\section{A. IDENTIFICATION}

\begin{tabular}{|c|c|c|c|}
\hline $\begin{array}{c}\mathrm{A} 01 \\
\mathrm{~A}\end{array}$ & 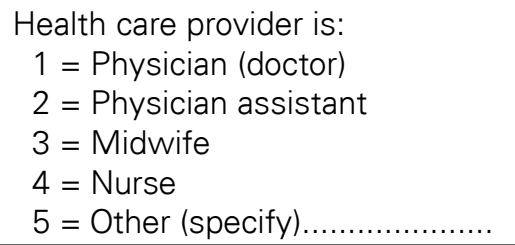 & B & $\begin{array}{l}\text { Sex of HCP: } \\
1=\text { Male } \\
2=\text { Female }\end{array}$ \\
\hline C & HCP was born in: ................... & $\mathrm{D}$ & $\begin{array}{l}\text { Education level of HCP } \\
\begin{aligned} 1 & =\text { Junior school } \\
2 & =\text { Secondary school } \\
3 & =\text { Higher }\end{aligned}\end{array}$ \\
\hline$E$ & $\begin{array}{l}\text { Marital status } \\
\begin{array}{l}1=\text { Single } \\
2=\text { Married } \\
3=\text { Separated } \\
4=\text { Divorced } \\
5=\text { Widowed }\end{array}\end{array}$ & $\mathrm{F}$ & $\begin{array}{l}\text { Religion } \\
\qquad \begin{aligned} 1 & =\text { None } \\
2 & =\text { Buddism } \\
3 & =\text { Christian } \\
4 & =\text { Other (specify) }\end{aligned}\end{array}$ \\
\hline G & \multicolumn{3}{|l|}{ 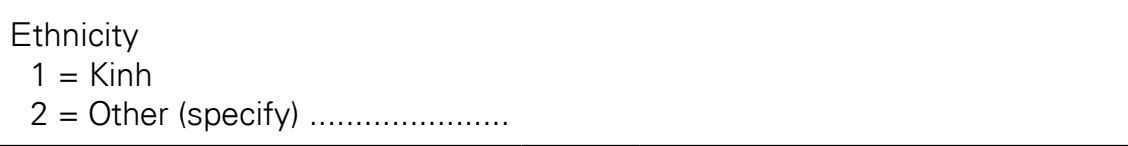 } \\
\hline A02 & $\begin{array}{l}\text { Unit where the HCP is working: } \\
1=\text { Health examination Unit } \\
2=\text { Emergency and Intensive } \\
\quad \text { Care Unit } \\
3=\text { Maternal unit } \\
4=\text { Trauma Centre } \\
5=\text { Family Planning Group } \\
6=\text { Commune Health Center } \\
7=\text { Other (specify)....................... }\end{array}$ & A03 & $\begin{array}{l}\text { Number of years of service at } \\
\text { this center? (rounded up) } \\
\ldots \ldots \ldots . . . . \text { (years) } \\
\text { (Less than } 12 \text { months }=1 \text { year) }\end{array}$ \\
\hline A04 & $\begin{array}{l}\text { Number of years working in the } \\
\text { health sector (rounded up) } \\
\ldots \ldots \ldots \ldots \ldots \ldots \ldots \ldots . . \text { (years) } \\
\text { (Less than } 12 \text { months = } 1 \text { year) }\end{array}$ & \multicolumn{2}{|c|}{ 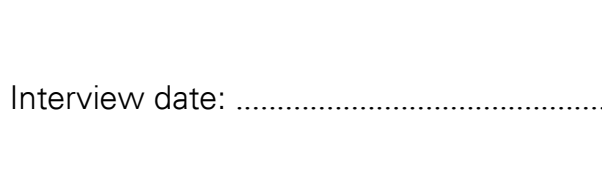 } \\
\hline
\end{tabular}




\section{B. PERCEPTION/KNOWLEDGE AND ATTITUDES ABOUT VIOLENCE AGAINST WOMEN}

\begin{tabular}{|c|c|c|c|c|c|c|}
\hline No. & Question & \multicolumn{5}{|c|}{ Code } \\
\hline B01 & $\begin{array}{l}\text { People may have different } \\
\text { views on the behaviors } \\
\text { between spouses in the } \\
\text { family. Do you agree or } \\
\text { disagree with the following } \\
\text { ideas? (read from a - e) }\end{array}$ & Agree & Disagree & $\begin{array}{c}\text { It } \\
\text { depends }\end{array}$ & $\begin{array}{l}\text { Do not } \\
\text { know/ } \\
\text { No } \\
\text { answer }\end{array}$ & \\
\hline a) & $\begin{array}{l}\text { The husband should demonstrate } \\
\text { to his spouse that he is the "boss" } \\
\text { of the family. }\end{array}$ & 1 & 2 & 3 & 4 & $\square$ \\
\hline b) & $\begin{array}{l}\text { A good wife should listen to her } \\
\text { spouse even if she disagrees with } \\
\text { his opinions or behaviors }\end{array}$ & 1 & 2 & 3 & 4 & $\square$ \\
\hline c) & $\begin{array}{l}\text { The woman is responsible for } \\
\text { satisfying her husband's sexual } \\
\text { demand even when she doesn't } \\
\text { want to }\end{array}$ & 1 & 2 & 3 & 4 & - \\
\hline d) & $\begin{array}{l}\text { Domestic conflicts should be } \\
\text { solved within the family (it's better } \\
\text { not to wash one's dirty linen in } \\
\text { public) }\end{array}$ & 1 & 2 & 3 & 4 & \\
\hline e) & $\begin{array}{l}\text { There should be external } \\
\text { intervention if the man frequently } \\
\text { beats his wife }\end{array}$ & 1 & 2 & 3 & 4 & \\
\hline B02 & $\begin{array}{l}\text { In your opinion, does a man } \\
\text { have the right to beat his } \\
\text { wife if she: (read from } a-g)\end{array}$ & Yes & No & It dep & ends & \\
\hline a) & $\begin{array}{l}\text { Does not fulfill household duties } \\
\text { as expected by her husband } \\
\text { (i.e. lazy, wasteful, neglect the } \\
\text { children, etc.) }\end{array}$ & 1 & 2 & 3 & & 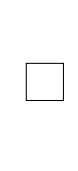 \\
\hline b) & $\begin{array}{l}\text { Is addicted to gambling and/or } \\
\text { drugs }\end{array}$ & 1 & 2 & 3 & & $\square$ \\
\hline c) & $\begin{array}{l}\text { Contravenes her husband's } \\
\text { opinions }\end{array}$ & 1 & 2 & 3 & & ] \\
\hline d) & Insults and abuses her spouse & 1 & 2 & 3 & & $\square$ \\
\hline e) & $\begin{array}{l}\text { Does not satisfy her husband's } \\
\text { sexual demand }\end{array}$ & 1 & 2 & 3 & & $\square$ \\
\hline
\end{tabular}




\begin{tabular}{|c|c|c|c|c|c|}
\hline f) & Has extra-marital relations & 1 & 2 & 3 & \begin{tabular}{|l|l|} 
\\
\end{tabular} \\
\hline g) & Others (specify) & 1 & 2 & 3 & $\square$ \\
\hline B03 & $\begin{array}{l}\text { In your opinion, a woman } \\
\text { has the right to refuse to } \\
\text { have sex with her spouse } \\
\text { when: (read from a - e) }\end{array}$ & Yes & No & $\begin{array}{l}\text { Do not know/ } \\
\text { No answer }\end{array}$ & \\
\hline a) & $\begin{array}{l}\text { She does not want to (without } \\
\text { specific reasons) }\end{array}$ & 1 & 2 & 3 & $\square$ \\
\hline b) & She is tired & 1 & 2 & 3 & $\square$ \\
\hline c) & Her husband is drunk & 1 & 2 & 3 & $\square$ \\
\hline d) & $\begin{array}{l}\text { Her husband treats her roughly/is } \\
\text { abusive }\end{array}$ & 1 & 2 & 3 & $\square$ \\
\hline e) & Others (specify).. & 2 & 3 & 3 & $\square$ \\
\hline B04 & $\begin{array}{l}\text { In your opinion, which of the } \\
\text { following behaviors should } \\
\text { be treated as/ considered } \\
\text { domestic violence against } \\
\text { women: (read from a-o) }\end{array}$ & Yes & No & $\begin{array}{l}\text { Do not know/ } \\
\text { No answer }\end{array}$ & \\
\hline a) & $\begin{array}{l}\text { Assaulting and hurting women } \\
\text { (i.e. smack, hit, kick, etc.) }\end{array}$ & 1 & 2 & 3 & $\square$ \\
\hline b) & Beating women during pregnancy & 1 & 2 & 3 & $\square$ \\
\hline c) & $\begin{array}{l}\text { Using sticks, canes or dangerous } \\
\text { tools (e.g., knife) to attack women }\end{array}$ & 1 & 2 & 3 & $\square$ \\
\hline d) & $\begin{array}{l}\text { Insulting, abusing, humiliating } \\
\text { women and making them feel } \\
\text { ashamed }\end{array}$ & 1 & 2 & 3 & $\square$ \\
\hline e) & Sending women away from home & 1 & 2 & 3 & $\square$ \\
\hline f) & $\begin{array}{l}\text { Abandoning, not taking care of the } \\
\text { women's work and health }\end{array}$ & 1 & 2 & 3 & $\square$ \\
\hline g) & $\begin{array}{l}\text { Threatening, controlling women } \\
\text { (i.e., using strength, weapon, } \\
\text { economic or emotional coercion, } \\
\text { or threats to do so) }\end{array}$ & 1 & 2 & 3 & $\square$ \\
\hline h) & $\begin{array}{l}\text { Preventing women from } \\
\text { participating in social activities/ } \\
\text { work/study }\end{array}$ & 1 & 2 & 3 & $\square$ \\
\hline i) & $\begin{array}{l}\text { Preventing women from } \\
\text { contacting their relatives/friends }\end{array}$ & 1 & 2 & 3 & $\square$ \\
\hline j) & $\begin{array}{l}\text { Preventing women from getting } \\
\text { medication or health care when } \\
\text { they are sick }\end{array}$ & 1 & 2 & 3 & $\square$ \\
\hline
\end{tabular}




\begin{tabular}{|c|c|c|c|c|c|}
\hline k) & $\begin{array}{l}\text { Forcing women to have more } \\
\text { children }\end{array}$ & 1 & 2 & 3 & $\square$ \\
\hline ।) & $\begin{array}{l}\text { Preventing women from using } \\
\text { contraception }\end{array}$ & 1 & 2 & 3 & $\square$ \\
\hline m) & $\begin{array}{l}\text { Forcing a wife to have sex when } \\
\text { she doesn't want to }\end{array}$ & 1 & 2 & 3 & $\square$ \\
\hline n) & Having extra-marital relationships & 1 & 2 & 3 & $\square$ \\
\hline o) & 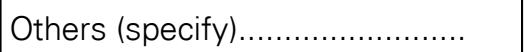 & 2 & 3 & 3 & $\square$ \\
\hline B05 & $\begin{array}{l}\text { With regard to the abusive } \\
\text { behaviors against women } \\
\text { mentioned above, how } \\
\text { do you judge the severity } \\
\text { of each? (Only ask if the } \\
\text { answers for BO4 = 1) } \\
\end{array}$ & $\begin{array}{l}\text { Very } \\
\text { serious }\end{array}$ & Serious & Not serious & \\
\hline a) & $\begin{array}{l}\text { Assaulting and hurting women } \\
\text { (i.e. smack, hit, kick, etc.) }\end{array}$ & 1 & 2 & 3 & $\square$ \\
\hline b) & Beating women during pregnancy & 1 & 2 & 3 & $\square$ \\
\hline c) & $\begin{array}{l}\text { Using sticks, canes or dangerous } \\
\text { tools (e.g., knife) to attack women }\end{array}$ & 1 & 2 & 3 & $\square$ \\
\hline d) & $\begin{array}{l}\text { Insulting, abusing, humiliating } \\
\text { women and making them feel } \\
\text { ashamed }\end{array}$ & 1 & 2 & 3 & 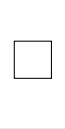 \\
\hline e) & Sending women away from home & 1 & 2 & 3 & $\square$ \\
\hline f) & $\begin{array}{l}\text { Abandoning, not taking care of the } \\
\text { women's work and health }\end{array}$ & 1 & 2 & 3 & 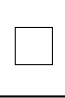 \\
\hline g) & $\begin{array}{l}\text { Threatening, controlling women } \\
\text { (i.e., using strength, weapon, } \\
\text { economic or emotional coercion, } \\
\text { or threats to do so) }\end{array}$ & 1 & 2 & 3 & $\square$ \\
\hline h) & $\begin{array}{l}\text { Preventing women from } \\
\text { participating in social activities/ } \\
\text { work/study }\end{array}$ & 1 & 2 & 3 & $\square$ \\
\hline i) & $\begin{array}{l}\text { Preventing women from } \\
\text { contacting their relatives/friends }\end{array}$ & 1 & 2 & 3 & $\square$ \\
\hline j) & $\begin{array}{l}\text { Preventing women from getting } \\
\text { medication or health care when } \\
\text { they are sick }\end{array}$ & 1 & 2 & 3 & $\square$ \\
\hline k) & $\begin{array}{l}\text { Forcing women to have more } \\
\text { children }\end{array}$ & 1 & 2 & 3 & $\square$ \\
\hline I) & $\begin{array}{l}\text { Preventing women from using } \\
\text { contraception }\end{array}$ & 1 & 2 & 3 & $\square$ \\
\hline
\end{tabular}




\begin{tabular}{|c|c|c|c|c|c|}
\hline m) & $\begin{array}{l}\text { Forcing a wife to have sex when } \\
\text { she doesn't want to }\end{array}$ & 1 & 2 & 3 & $\square$ \\
\hline n) & Having extra-marital relationships & 1 & 2 & 3 & $\square$ \\
\hline o) & \begin{tabular}{|l} 
Others \\
(specify) .............................
\end{tabular} & 1 & 2 & 3 & 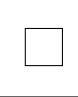 \\
\hline B06 & $\begin{array}{l}\text { In your opinion, are these } \\
\text { following behaviors of } \\
\text { violence against women } \\
\text { common in your locality? } \\
\text { (Only ask if the answers for } \\
\text { BO4 = 1; read from a-o) }\end{array}$ & Yes & No & $\begin{array}{l}\text { Do not know/ } \\
\text { No answer }\end{array}$ & \\
\hline a) & $\begin{array}{l}\text { Assaulting and hurting women } \\
\text { (i.e. smack, hit, kick, etc.) }\end{array}$ & 1 & 2 & 3 & $\square$ \\
\hline b) & Beating women during pregnancy & 1 & 2 & 3 & 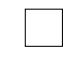 \\
\hline c) & $\begin{array}{l}\text { Using sticks, canes or dangerous } \\
\text { tools (e.g., knife) to attack women }\end{array}$ & 1 & 2 & 3 & \\
\hline d) & $\begin{array}{l}\text { Insulting, abusing, humiliating } \\
\text { women and making them feel } \\
\text { ashamed }\end{array}$ & 1 & 2 & 3 & \\
\hline e) & Sending women away from home & 1 & 2 & 3 & 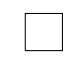 \\
\hline f) & $\begin{array}{l}\text { Abandoning, not taking care of the } \\
\text { women's work and health }\end{array}$ & 1 & 2 & 3 & \\
\hline g) & $\begin{array}{l}\text { Threatening, controlling women } \\
\text { (i.e., using strength, weapon, } \\
\text { economic or emotional coercion, } \\
\text { or threats to do so) }\end{array}$ & 1 & 2 & 3 & \\
\hline h) & $\begin{array}{l}\text { Preventing women from } \\
\text { participating in social activities/ } \\
\text { work/study }\end{array}$ & 1 & 2 & 3 & \\
\hline i) & $\begin{array}{l}\text { Prventing women from contacting } \\
\text { their relatives/friends }\end{array}$ & 1 & 2 & 3 & $\square$ \\
\hline j) & $\begin{array}{l}\text { Preventing women from getting } \\
\text { medication or health care when } \\
\text { they are sick }\end{array}$ & 1 & 2 & 3 & \\
\hline k) & $\begin{array}{l}\text { Forcing women to have more } \\
\text { children }\end{array}$ & 1 & 2 & 3 & $\square$ \\
\hline ।) & $\begin{array}{l}\text { Preventing women from using } \\
\text { contraception }\end{array}$ & 1 & 2 & 3 & \\
\hline
\end{tabular}




\begin{tabular}{|c|c|c|c|c|c|}
\hline m) & $\begin{array}{l}\text { Forcing a wife to have sex when } \\
\text { she doesn't want to }\end{array}$ & 1 & 2 & 3 & $\square$ \\
\hline n) & Having extra-marital relationships & 1 & 2 & 3 & $\square$ \\
\hline o) & Others (specify).... & 1 & 2 & 3 & $\square$ \\
\hline B07 & $\begin{array}{l}\text { According to your } \\
\text { assessment, what are the } \\
\text { causes leading to violence } \\
\text { against women? (Do not } \\
\text { read the list, but ask them } \\
\text { to mention the causes...) }\end{array}$ & Mention & $\begin{array}{c}\text { Not } \\
\text { mention }\end{array}$ & $\begin{array}{l}\text { Do not know/ } \\
\text { No answer }\end{array}$ & \\
\hline a) & The influence of male chauvinism & 1 & 2 & 3 & $\square$ \\
\hline b) & Economic difficulties & 1 & 2 & 3 & $\square$ \\
\hline c) & $\begin{array}{l}\text { Conflicts between the wife and } \\
\text { the husband }\end{array}$ & 1 & 2 & 3 & $\square$ \\
\hline d) & $\begin{array}{l}\text { Conflicts between the wife and } \\
\text { in-laws }\end{array}$ & 1 & 2 & 3 & $\square$ \\
\hline e) & $\begin{array}{l}\text { Gambling, drinking, and/or drugs } \\
\text { addiction }\end{array}$ & 1 & 2 & 3 & $\square$ \\
\hline f) & $\begin{array}{l}\text { Disagreements about childrens' } \\
\text { education }\end{array}$ & 1 & 2 & 3 & $\square$ \\
\hline g) & $\begin{array}{l}\text { One spouse has extra marital } \\
\text { relationships }\end{array}$ & 1 & 2 & 3 & $\square$ \\
\hline h) & $\begin{array}{l}\text { Sexual issues between wife and } \\
\text { husband }\end{array}$ & 1 & 2 & 3 & $\square$ \\
\hline i) & Others (specify)....... & 1 & 2 & 3 & $\square$ \\
\hline B08 & $\begin{array}{l}\text { In your opinion, what } \\
\text { are the consequences of } \\
\text { violence against women? } \\
\text { (Do not read) }\end{array}$ & Mention & $\begin{array}{c}\text { Not } \\
\text { mention }\end{array}$ & $\begin{array}{l}\text { Do not know/ } \\
\text { No answer }\end{array}$ & \\
\hline a) & $\begin{array}{l}\text { Impact on the woman's physical } \\
\text { health, or threat to her life }\end{array}$ & 1 & 2 & 3 & $\square$ \\
\hline b) & $\begin{array}{l}\text { Impact on the woman's mental } \\
\text { health }\end{array}$ & 1 & 2 & 3 & $\square$ \\
\hline c) & $\begin{array}{l}\text { Impact on the woman's } \\
\text { reproductive health }\end{array}$ & 1 & 2 & 3 & $\square$ \\
\hline d) & $\begin{array}{l}\text { Impact on the development of her } \\
\text { children }\end{array}$ & 1 & 2 & 3 & $\square$ \\
\hline
\end{tabular}




\begin{tabular}{|c|c|c|c|c|c|}
\hline e) & $\begin{array}{l}\text { Impact on family happiness (e.g., } \\
\text { broken family) }\end{array}$ & 1 & 2 & 3 & $\square$ \\
\hline f) & Impact on family economy & 1 & 2 & 3 & $\square$ \\
\hline g) & $\begin{array}{l}\text { Others } \\
\text { (specify)....... }\end{array}$ & 1 & 2 & 3 & $\square$ \\
\hline B09 & $\begin{array}{l}\text { In your opinion, can these } \\
\text { following types of forced } \\
\text { sexual behaviors be } \\
\text { considered violence against } \\
\text { women or children? }\end{array}$ & Yes & No & $\begin{array}{l}\text { Do not know/ } \\
\text { No answer }\end{array}$ & \\
\hline a) & Rape, sexual assault & 1 & 2 & 3 & $\square$ \\
\hline b) & $\begin{array}{l}\text { Rape, sexual assault of children or } \\
\text { any types of child sexual abuse }\end{array}$ & 1 & 2 & 3 & $\square$ \\
\hline c) & Others (specify)... & 1 & 2 & 3 & $\square$ \\
\hline B10 & $\begin{array}{l}\text { How do you assess } \\
\text { the severity of the } \\
\text { aforementioned behaviors? } \\
\text { (Ask only if the answers for } \\
\text { B09=1) }\end{array}$ & $\begin{array}{c}\text { Very } \\
\text { serious }\end{array}$ & Serious & Not serious & \\
\hline a) & Rape, sexual assault & 1 & 2 & 3 & $\square$ \\
\hline b) & $\begin{array}{l}\text { Rape, sexual assault against } \\
\text { children or any type of child sexual } \\
\text { abuse }\end{array}$ & 1 & 2 & 3 & $\square$ \\
\hline o) & Others (specify)... & 1 & 2 & 3 & $\square$ \\
\hline B11 & $\begin{array}{l}\text { In your opinion, what are } \\
\text { the causes leading to sexual } \\
\text { violence (rape, sexual } \\
\text { harassment...)? (Do not read, } \\
\text { ask "any other reasons?") }\end{array}$ & Mention & $\begin{array}{c}\text { Not } \\
\text { mention }\end{array}$ & $\begin{array}{l}\text { Do not know/ } \\
\text { No answer }\end{array}$ & \\
\hline a) & Influence of sex/porn movies & 1 & 2 & 3 & $\square$ \\
\hline b) & Influence of alcohol, drugs & 1 & 2 & 3 & $\square$ \\
\hline c) & $\begin{array}{l}\text { Changing of traditional ethical } \\
\text { values (modernization) }\end{array}$ & 1 & 2 & 3 & $\square$ \\
\hline d) & 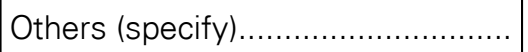 & 1 & 2 & 3 & $\square$ \\
\hline B12 & $\begin{array}{l}\text { In your opinion, what are the } \\
\text { consequences of rape and } \\
\text { sexual assault against women } \\
\text { and girls? (Do not read) }\end{array}$ & Mention & $\begin{array}{c}\text { Not } \\
\text { mention }\end{array}$ & $\begin{array}{l}\text { Do not know/ } \\
\text { No answer }\end{array}$ & \\
\hline a) & $\begin{array}{l}\text { Impact on the physical health, or } \\
\text { threat to her life }\end{array}$ & 1 & 2 & 3 & $\square$ \\
\hline
\end{tabular}




\begin{tabular}{|c|c|c|c|c|c|}
\hline b) & Impact on the mental health & 1 & 2 & 3 & $\square$ \\
\hline c) & Impact on the reproductive health & 1 & 2 & 3 & $\square$ \\
\hline d) & $\begin{array}{l}\text { Impact on child long-term } \\
\text { development }\end{array}$ & 1 & 2 & 3 & $\square$ \\
\hline e) & 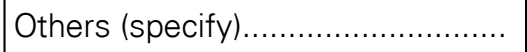 & 1 & 2 & 3 & $\square$ \\
\hline B13 & $\begin{array}{l}\text { Do you know any legal } \\
\text { regulations or penalties for } \\
\text { behaviors of violence against } \\
\text { women (e.g., domestic } \\
\text { violence, rape/sexual } \\
\text { assault)? } \\
\quad 1=\text { Yes } \\
2=\mathrm{No} \mathrm{--->} \mathrm{Move} \mathrm{to} \mathrm{B15}\end{array}$ & & & & \\
\hline B14 & $\begin{array}{l}\text { If Yes, what are the } \\
\text { behaviors that break the law? } \\
\text { (Do not read, ask "any other } \\
\text { reasons?") }\end{array}$ & Mention & $\begin{array}{c}\text { Not } \\
\text { mention }\end{array}$ & $\begin{array}{c}\text { Do not know/ No } \\
\text { answer }\end{array}$ & \\
\hline a) & Physical violence (murder, injury, etc.) & 1 & 2 & 3 & $\square$ \\
\hline b) & $\begin{array}{l}\text { Psychological violence/Verbal } \\
\text { abuse (force to suicide, threaten to } \\
\text { murder, insult/slander, etc.) }\end{array}$ & 1 & 2 & 3 & $\square$ \\
\hline c) & $\begin{array}{l}\text { Violation of the principal of marital } \\
\text { monogamy }\end{array}$ & 1 & 2 & 3 & \\
\hline d) & $\begin{array}{l}\text { Rape, sexual assault, and any } \\
\text { types of child sexual abuse }\end{array}$ & 1 & 2 & 3 & ] \\
\hline e) & 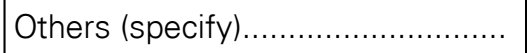 & 1 & 2 & 3 & $\square$ \\
\hline B15 & $\begin{array}{l}\text { Have you known/heard } \\
\text { about the laws against } \\
\text { domestic violence that have } \\
\text { been recently issued by the } \\
\text { Government? } \\
\quad \begin{array}{l}1=\text { Yes } \\
2=\mathrm{No}-->\text { Move to C01 }\end{array}\end{array}$ & & & & \\
\hline B16 & $\begin{array}{l}\text { If yes, do you know any } \\
\text { legal regulations on } \\
\text { provision of health services } \\
\text { to the victims of domestic } \\
\text { violence at health facilities? } \\
\text { (The interviewer asks more } \\
\text { about the regulations if the } \\
\text { HCP says Yes) } \\
1=\mathrm{Yes} \\
2=\mathrm{No}\end{array}$ & & & & \\
\hline
\end{tabular}




\section{EXPERIENCE OF WORKING WITH THE PATIENTS WHO ARE VICTIMS OF GENDER VIOLENCE}

\begin{tabular}{|c|c|c|c|c|}
\hline C01 & $\begin{array}{l}\text { Since working at this center, } \\
\text { have you ever met, known, or } \\
\text { heard about any female patients } \\
\text { who are victims of violence } \\
\text { (domestic violence, sexual } \\
\text { assault) as mentioned above? } \\
1=\text { Yes } \\
2=\text { No ---> Move to C06 }\end{array}$ & & & \\
\hline C02 & $\begin{array}{l}\text { Have you ever met any female } \\
\text { patients who are victims of } \\
\text { violence (domestic violence, } \\
\text { sexual assault) as mentioned } \\
\text { above at your unit? } \\
1=\text { Yes } \\
2 \text { = No ---> Move to C06 }\end{array}$ & & & \\
\hline C03 & $\begin{array}{l}\text { How do you know that they } \\
\text { are the victims of violence? } \\
\text { (Do not read, ask "any other } \\
\text { reasons?") }\end{array}$ & Mentioned & Not mentioned & \\
\hline a) & By looking at the wound/injury & 1 & 2 & $\square$ \\
\hline b) & By asking the patient directly & 1 & 2 & $\square$ \\
\hline c) & The patient tells & 1 & 2 & $\square$ \\
\hline d) & The patent's relatives tell & 1 & 2 & $\square$ \\
\hline e) & Other HCPs tell & 1 & 2 & $\square$ \\
\hline f) & 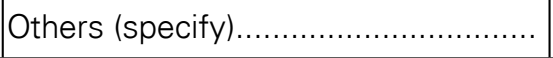 & 1 & 2 & $\square$ \\
\hline C04 & $\begin{array}{l}\text { For those who were victims } \\
\text { of violence, which types } \\
\text { of violence had they } \\
\text { experienced? (Read from a - p) }\end{array}$ & Mentioned & Not mentioned & \\
\hline a) & $\begin{array}{l}\text { Assaulting and hurting women (i.e. } \\
\text { smack, hit, kick, etc.) }\end{array}$ & 1 & 2 & ] \\
\hline b) & Beating women during pregnancy & 1 & 2 & $\square$ \\
\hline c) & $\begin{array}{l}\text { Using sticks, canes or dangerous } \\
\text { tools (e.g., knife) to attack women }\end{array}$ & 1 & 2 & \\
\hline d) & $\begin{array}{l}\text { Insulting, abusing, humiliating women } \\
\text { and making them feel ashamed }\end{array}$ & 1 & 2 & \\
\hline e) & Sending women away from home & 1 & 2 & $\square$ \\
\hline
\end{tabular}




\begin{tabular}{|c|c|c|c|c|}
\hline f) & $\begin{array}{l}\text { Abandoning, not taking care of the } \\
\text { women's work and health }\end{array}$ & 1 & 2 & $\square$ \\
\hline g) & $\begin{array}{l}\text { Threatening, controlling women } \\
\text { (i.e., using strength, weapon, } \\
\text { economic or emotional coercion, or } \\
\text { threats to do so) }\end{array}$ & 1 & 2 & \\
\hline h) & $\begin{array}{l}\text { Preventing women from } \\
\text { participating in social activities/ } \\
\text { work/study }\end{array}$ & 1 & 2 & \\
\hline i) & $\begin{array}{l}\text { Preventing women from contacting } \\
\text { their relatives/friends }\end{array}$ & 1 & 2 & \\
\hline j) & $\begin{array}{l}\text { Preventing women from getting } \\
\text { medication or health care when they } \\
\text { are sick }\end{array}$ & 1 & 2 & \rfloor \\
\hline k) & $\begin{array}{l}\text { Forcing women to have more } \\
\text { children }\end{array}$ & 1 & 2 & ] \\
\hline ।) & $\begin{array}{l}\text { Preventing women from using } \\
\text { contraception }\end{array}$ & 1 & 2 & \\
\hline m) & $\begin{array}{l}\text { Forcing a wife to have sex when } \\
\text { she doesn't want to }\end{array}$ & 1 & 2 & $J$ \\
\hline n) & Having extra-marital relationships & 1 & 2 & $\square$ \\
\hline o) & Rape/sexual assault & 1 & 2 & $\square$ \\
\hline p) & Others (specify)... & 1 & 2 & $\square$ \\
\hline C05 & $\begin{array}{l}\text { For those who were victims } \\
\text { of violence, which types } \\
\text { of violence had they } \\
\text { experienced? } \\
\text { (Read from a - h) }\end{array}$ & Mentioned & Not mentioned & \\
\hline a) & $\begin{array}{l}\text { Exterior wound/injury (bruises, cuts, } \\
\text { swelling) }\end{array}$ & 1 & 2 & \\
\hline b) & Broken limbs & 1 & 2 & $\square$ \\
\hline c) & $\begin{array}{l}\text { Injury in dangerous areas (head, } \\
\text { chest, and stomach) }\end{array}$ & 1 & 2 & \\
\hline d) & Miscarriage & 1 & 2 & $\square$ \\
\hline e) & Wound/injury to genital organs & 1 & 2 & $\square$ \\
\hline f) & Wound/injury to internal organs & 1 & 2 & $\square$ \\
\hline g) & $\begin{array}{l}\text { Mental trauma (anxiety, panic, } \\
\text { psychological disorder, etc.) }\end{array}$ & 1 & 2 & \\
\hline h) & 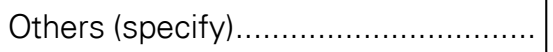 & 1 & 2 & $\square$ \\
\hline
\end{tabular}




\begin{tabular}{|c|c|c|c|c|c|c|}
\hline C06 & $\begin{array}{l}\text { Have you examined such } \\
\text { patients directly? } \\
\begin{array}{l}1=\text { Yes } \\
2=\text { No ---> Move to C12 }\end{array}\end{array}$ & & & & & \\
\hline $\mathrm{CO}$ & $\begin{array}{l}\text { When examining patients, do } \\
\text { you ever ask them directly } \\
\text { whether they have been } \\
\text { physically or psychologically } \\
\text { abused? } \\
\quad 1=\text { Yes } \\
\quad 2=\text { No ---> Move to C9 }\end{array}$ & & & & & $\square$ \\
\hline $\mathrm{Co8}$ & $\begin{array}{l}\text { If Yes, in which cases do } \\
\text { you ask and do you do this } \\
\text { frequently? }\end{array}$ & Frequently & Som & imes & Never & \\
\hline a) & At the initial patient visit/contact & 1 & & & 3 & $\square$ \\
\hline b) & At routine check-ups & 1 & & & 3 & $\square$ \\
\hline c) & When examining injured patients & 1 & & & 3 & $\square$ \\
\hline d) & At the first prenatal check-up & 1 & & & 3 & $\square$ \\
\hline e) & At regular prenatal check-ups & 1 & & & 3 & $\square$ \\
\hline f) & 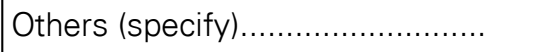 & 1 & & & 3 & $\square$ \\
\hline \multicolumn{7}{|c|}{ Move to C10 } \\
\hline C09 & $\begin{array}{l}\text { It is difficult to ask female } \\
\text { patients about violence } \\
\text { against women. For what } \\
\text { reasons would you hesitate } \\
\text { to ask about this issue? (Do } \\
\text { not read, let the interviewee } \\
\text { answer and then ask "any } \\
\text { other reasons?") }\end{array}$ & \multicolumn{2}{|c|}{ Mentioned } & \multicolumn{2}{|c|}{ Not mentioned } & \\
\hline a) & Lack of time & \multicolumn{2}{|l|}{1} & & 2 & $\square$ \\
\hline b) & Feel uncomfortable to ask & \multicolumn{2}{|l|}{1} & & 2 & $\square$ \\
\hline c) & Think that I can not help them & \multicolumn{2}{|l|}{1} & & 2 & $\square$ \\
\hline d) & Consider it their private business & \multicolumn{2}{|l|}{1} & & 2 & $\square$ \\
\hline e) & $\begin{array}{l}\text { Afraid that patients are ashamed/ } \\
\text { embarrassed }\end{array}$ & \multicolumn{2}{|l|}{1} & & 2 & 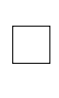 \\
\hline f) & $\begin{array}{l}\text { Consider physical treatment the } \\
\text { priority }\end{array}$ & \multicolumn{2}{|l|}{1} & & 2 & $\square$ \\
\hline g) & $\begin{array}{l}\text { Have not been trained on how to } \\
\text { screen for violence as the cause of } \\
\text { injuries }\end{array}$ & \multicolumn{2}{|l|}{1} & & 2 & $\square$ \\
\hline
\end{tabular}




\begin{tabular}{|c|c|c|c|c|c|}
\hline h) & $\begin{array}{l}\text { Patients refuse to talk about their } \\
\text { history }\end{array}$ & \multicolumn{2}{|l|}{1} & 2 & $\square$ \\
\hline i) & Patients are addicted to alcohol & \multicolumn{2}{|l|}{1} & 2 & $\square$ \\
\hline j) & $\begin{array}{l}\text { Patients refuse to answer when } \\
\text { they are asked }\end{array}$ & \multicolumn{2}{|l|}{1} & 2 & $\square$ \\
\hline k) & $\begin{array}{l}\text { Patients are accompanied by their } \\
\text { relatives }\end{array}$ & \multicolumn{2}{|l|}{1} & 2 & $\square$ \\
\hline l) & $\begin{array}{l}\text { There is no treatment protocol/ } \\
\text { guideline on this }\end{array}$ & \multicolumn{2}{|l|}{1} & 2 & 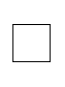 \\
\hline m) & $\begin{array}{l}\text { Insufficient resources to support } \\
\text { patients }\end{array}$ & \multicolumn{2}{|l|}{1} & 2 & $L$ \\
\hline n) & 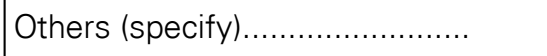 & \multicolumn{2}{|l|}{1} & 2 & $\square$ \\
\hline C10 & $\begin{array}{l}\text { How do you deal with patients } \\
\text { who are violence victims? }\end{array}$ & $\begin{array}{l}\text { Almost all } \\
\text { cases }\end{array}$ & Sometimes & Never & \\
\hline a) & $\begin{array}{l}\text { Keep them at the unit and deal with } \\
\text { them }\end{array}$ & 1 & 2 & 3 & $\square$ \\
\hline b) & $\begin{array}{l}\text { Transfer them to (upper level, } \\
\text { other units, or counseling centers, } \\
\text { if any) }\end{array}$ & 1 & 2 & 3 & $\square$ \\
\hline c) & $\begin{array}{l}\text { Is is not the unit's function/ } \\
\text { responsibility to deal with it }\end{array}$ & 1 & 2 & 3 & $\square$ \\
\hline d) & 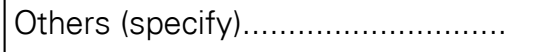 & 1 & 2 & 3 & $\square$ \\
\hline C11 & $\begin{array}{l}\text { If transfer is required, then } \\
\text { what are the reasons? (Do not } \\
\text { read) (Only answer if } C 10 b=1 \\
\text { or 2) }\end{array}$ & Mentioned & $\begin{array}{c}\text { Not } \\
\text { mentioned }\end{array}$ & $\begin{array}{c}\text { Not } \\
\text { applicable }\end{array}$ & \\
\hline a) & $\begin{array}{l}\text { Serious cases, beyond our } \\
\text { professional capacity }\end{array}$ & 1 & 2 & 3 & $\square$ \\
\hline b) & $\begin{array}{l}\text { The center does not have sufficient } \\
\text { equipment for diagnosis and } \\
\text { treatment services }\end{array}$ & 1 & 2 & 3 & $\square$ \\
\hline c) & Beyond our function/responsibility & 1 & 2 & 3 & $\square$ \\
\hline d) & Others (specify)... & 1 & 2 & 3 & $\square$ \\
\hline
\end{tabular}




\begin{tabular}{|c|c|c|c|c|c|}
\hline C12 & 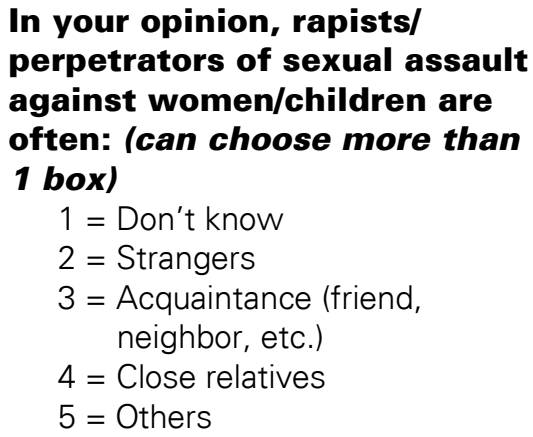 & & & & \begin{tabular}{|l|}
$\square$ \\
$\square$
\end{tabular} \\
\hline C13 & $\begin{array}{l}\text { In your opinion, who at your } \\
\text { health facility would be } \\
\text { responsible for providing } \\
\text { medical treatment to victims } \\
\text { of violence? }\end{array}$ & Yes & No & $\begin{array}{c}\text { Do not } \\
\text { know/ } \\
\text { No } \\
\text { answer }\end{array}$ & \\
\hline a) & Physicians/doctors & 1 & 2 & 3 & $\square$ \\
\hline b) & Nurses & 1 & 2 & 3 & $\square$ \\
\hline c) & Physician assistants & 1 & 2 & 3 & $\square$ \\
\hline d) & Midwives & 1 & 2 & 3 & $\square$ \\
\hline e) & All the above & 1 & 2 & 3 & $\square$ \\
\hline f) & 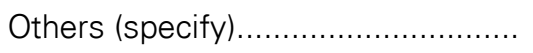 & 1 & 2 & 3 & $\square$ \\
\hline C14 & $\begin{array}{l}\text { In your opinion, who at your } \\
\text { health facility would be } \\
\text { responsible for providing } \\
\text { other support (beyond } \\
\text { medical treatment), to the } \\
\text { victims of violence? }\end{array}$ & Yes & No & $\begin{array}{c}\text { Do not } \\
\text { know/ } \\
\text { No } \\
\text { answer }\end{array}$ & \\
\hline a) & Physicians/doctors & 1 & 2 & 3 & $\square$ \\
\hline b) & Nurses & 1 & 2 & 3 & $\square$ \\
\hline c) & Physician assistants & 1 & 2 & 3 & $\square$ \\
\hline d) & Midwives & 1 & 2 & 3 & $\square$ \\
\hline e) & All the above & 1 & 2 & 3 & $\square$ \\
\hline f) & Others (specify).. & 1 & 2 & 3 & $\square$ \\
\hline
\end{tabular}




\begin{tabular}{|c|c|c|c|c|c|}
\hline C15 & $\begin{array}{l}\text { When you know or suspect } \\
\text { that a female patient is the } \\
\text { victim of violence, what do } \\
\text { you often do, beyond medical } \\
\text { services? (Do not read, ask } \\
\text { "anything else...?") }\end{array}$ & Mentioned & \multicolumn{2}{|c|}{ Not mentioned } & \\
\hline a) & Emotional/spiritual support & 1 & \multicolumn{2}{|c|}{2} & $\square$ \\
\hline b) & $\begin{array}{l}\text { Give advice on how to protect } \\
\text { herself and her children }\end{array}$ & 1 & \multicolumn{2}{|c|}{2} & 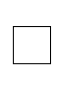 \\
\hline c) & $\begin{array}{l}\text { Provide the patient with information } \\
\text { about other places where she can } \\
\text { get support (government or legal } \\
\text { agencies, police offices) }\end{array}$ & 1 & \multicolumn{2}{|c|}{2} & \\
\hline d) & $\begin{array}{l}\text { Refer the patient to counseling } \\
\text { services }\end{array}$ & 1 & \multicolumn{2}{|c|}{2} & \\
\hline e) & $\begin{array}{l}\text { Arrange for temporary residence for } \\
\text { the patient if she doesn't want to } \\
\text { go back home }\end{array}$ & 1 & \multicolumn{2}{|c|}{2} & 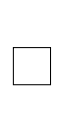 \\
\hline f) & $\begin{array}{l}\text { Continue to provide support after } \\
\text { she leaves the hospital if she } \\
\text { requests it }\end{array}$ & 1 & \multicolumn{2}{|c|}{2} & L \\
\hline g) & 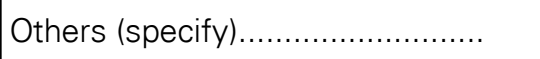 & 1 & \multicolumn{2}{|c|}{2} & $\square$ \\
\hline C16 & $\begin{array}{l}\text { When you know that a female } \\
\text { patient is the victim of a } \\
\text { sexual assault, what do you } \\
\text { do in addition to medical } \\
\text { check-up and treatment } \\
\text { service? (Do not read, let the } \\
\text { interviewee answer and then } \\
\text { ask"anything else?") }\end{array}$ & Mentioned & $\begin{array}{l}\text { Not } \\
\text { mentioned }\end{array}$ & $\begin{array}{c}\text { Not } \\
\text { applicable }\end{array}$ & \\
\hline a) & Emotional/spiritual support & 1 & 2 & 3 & $\square$ \\
\hline b) & $\begin{array}{l}\text { Give advice on how to protect } \\
\text { herself and her children }\end{array}$ & 1 & 2 & 3 & 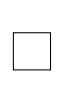 \\
\hline c) & $\begin{array}{l}\text { Provide the patient with information } \\
\text { about the places where she can } \\
\text { get support (government or legal } \\
\text { agencies, police offices) }\end{array}$ & 1 & 2 & 3 & \\
\hline d) & $\begin{array}{l}\text { Refer the patient to counseling } \\
\text { centers }\end{array}$ & 1 & 2 & 3 & $\square$ \\
\hline
\end{tabular}




\begin{tabular}{|c|c|c|c|c|c|}
\hline e) & $\begin{array}{l}\text { Continue to provide support after } \\
\text { she leaves the hospital if she } \\
\text { requests it }\end{array}$ & 1 & 2 & 3 & $\square$ \\
\hline g) & 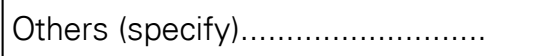 & 1 & 2 & 3 & $\square$ \\
\hline C17 & $\begin{array}{l}\text { How many victims of violence } \\
\text { have you provided health } \\
\text { services to over the last } 2 \\
\text { years? ............................ } \\
\text { If you don't remember, write } \\
\text { code } 99\end{array}$ & & & & \\
\hline C18 & $\begin{array}{l}\text { Do you know any centers } \\
\text { that provide support to the } \\
\text { victims of violence (domestic } \\
\text { violence, sexual assult)? } \\
1=\text { Yes } \\
2=\text { No ---> Move to C20 }\end{array}$ & & & & \\
\hline C19 & $\begin{array}{l}\text { If Yes, which agencies and } \\
\text { organizations? } \\
\text { (Do not read, let the } \\
\text { interviewee answer and then } \\
\text { ask "any other agencies/ } \\
\text { organizations?") }\end{array}$ & Yes & No & $\begin{array}{l}\text { Do not } \\
\text { know/ } \\
\text { No } \\
\text { answer }\end{array}$ & \\
\hline a) & Police offices & 1 & 2 & 3 & $\square$ \\
\hline b) & Judicial offices/Courts & 1 & 2 & 3 & $\square$ \\
\hline c) & Government authorities & 1 & 2 & 3 & $\square$ \\
\hline d) & Women's Union & 1 & 2 & 3 & $\square$ \\
\hline e) & Youth Union & 1 & 2 & 3 & $\square$ \\
\hline f) & Mediation groups & 1 & 2 & 3 & $\square$ \\
\hline g) & Counseling centers & 1 & 2 & 3 & $\square$ \\
\hline h) & $\begin{array}{l}\text { Others } \\
\text { (specify) } \ldots \ldots \ldots \ldots \ldots \ldots \ldots \ldots \ldots \ldots \ldots \ldots \ldots \ldots \ldots \ldots \ldots\end{array}$ & 1 & 2 & 3 & $\square$ \\
\hline $\mathrm{C} 20$ & $\begin{array}{l}\text { Has your center collaborated } \\
\text { with the local authorities } \\
\text { to provide support to the } \\
\text { victims of violence? } \\
1=\text { Yes } \\
2=\text { No ---> Move to C23 }\end{array}$ & & & & $\square$ \\
\hline
\end{tabular}




\begin{tabular}{|c|c|c|c|c|c|}
\hline C21 & $\begin{array}{l}\text { If Yes, with which agencies? } \\
\text { (do not read, ask "any other } \\
\text { agencies?") }\end{array}$ & Yes & No & $\begin{array}{l}\text { Do not } \\
\text { know/ } \\
\text { No } \\
\text { answer }\end{array}$ & \\
\hline a) & Police offices & 1 & 2 & 3 & $\square$ \\
\hline b) & Judicial offices/Courts & 1 & 2 & 3 & $\square$ \\
\hline c) & Government authorities & 1 & 2 & 3 & $\square$ \\
\hline d) & Women's Union & 1 & 2 & 3 & $\square$ \\
\hline e) & Youth Union & 1 & 2 & 3 & $\square$ \\
\hline f) & Mediation groups & 1 & 2 & 3 & $\square$ \\
\hline g) & Counseling centers & 1 & 2 & 3 & $\square$ \\
\hline h) & 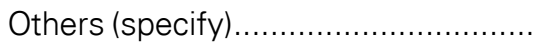 & 1 & 2 & 3 & $\square$ \\
\hline C22 & $\begin{array}{l}\text { Does the hospital/health } \\
\text { facility have any specific } \\
\text { treatment guidelines/protocol } \\
\text { on providing services to the } \\
\text { victims of violence? } \\
\begin{array}{l}1=\text { Yes } \\
2=\text { No } \\
\text { 3= Do not know/No answer }\end{array}\end{array}$ & & & & \\
\hline C23 & $\begin{array}{l}\text { Does the hospital/health } \\
\text { facility have a list of } \\
\text { agencies/organizations to } \\
\text { which you can refer violence } \\
\text { victims to go for support? } \\
\begin{array}{l}1=\text { Yes } \\
2=\text { No } \\
\text { 3= Do not know/No answer }\end{array}\end{array}$ & & & & 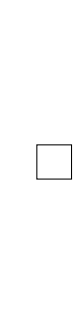 \\
\hline C24 & $\begin{array}{l}\text { Do you know any materials } \\
\text { that provide guidance to } \\
\text { HCPs on how to work with } \\
\text { the victims of violence? } \\
1=\text { Yes } \\
2=\text { No ---> Move to C28 }\end{array}$ & & & & $\square$ \\
\hline C25 & $\begin{array}{l}\text { Do you use those materials? } \\
\begin{array}{l}1=\text { Yes } \\
2=\text { No ---> Move to C28 }\end{array}\end{array}$ & & & & $\square$ \\
\hline
\end{tabular}




\begin{tabular}{|c|c|c|c|c|}
\hline C26 & 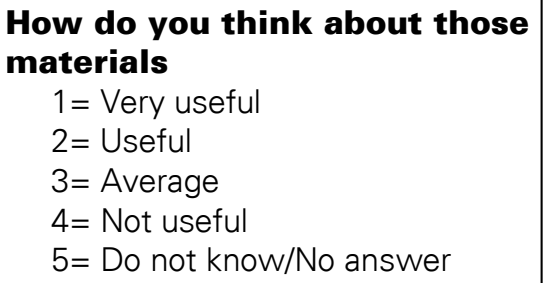 & & & $\square$ \\
\hline C27 & 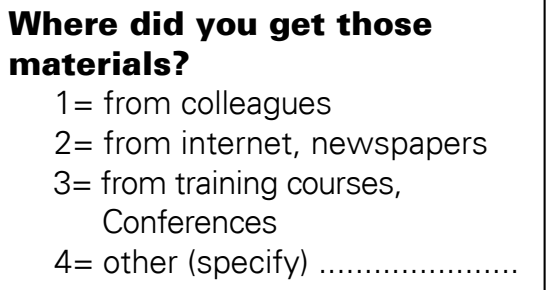 & & & $\square$ \\
\hline C28 & 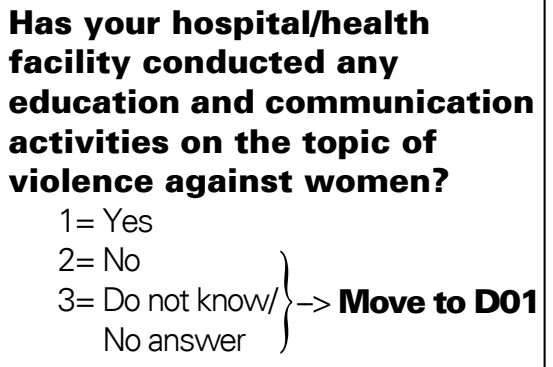 & & & \\
\hline C29 & If Yes, they are: & Yes & No & \\
\hline a) & Patients' number cards & 1 & 2 & ] \\
\hline b) & Leaflets, booklets & 1 & 2 & ] \\
\hline c) & Banners, posters & 1 & 2 & $\square$ \\
\hline d) & Others (specify).... & 1 & 2 & ] \\
\hline
\end{tabular}




\section{RECOMMENDATIONS FOR IMPROVING CAPACITY TO SUPPORT VICTIMS OF VIOLENCE}

\begin{tabular}{|c|c|c|c|c|c|}
\hline D01 & $\begin{array}{l}\text { Do you think that there } \\
\text { are sufficient resources in } \\
\text { the community to support } \\
\text { victims of violence? } \\
1=\text { Yes ---> Move to D03 } \\
2=\text { No }\end{array}$ & & & & \\
\hline D02 & $\begin{array}{l}\text { If No then Why? } \\
\text { (Do not read, ask "what is } \\
\text { lacking...?") }\end{array}$ & Mentioned & & Vot mentioned & $L^{\prime}$ \\
\hline a) & $\begin{array}{l}\text { Insufficient and inadequate } \\
\text { perception/knowledge of the } \\
\text { government authorities at different } \\
\text { levels }\end{array}$ & 1 & & 2 & $\square$ \\
\hline b) & $\begin{array}{l}\text { HCPs' lack of skills on approaching } \\
\text { and consulting victims }\end{array}$ & 1 & & 2 & $\square$ \\
\hline c) & $\begin{array}{l}\text { Lack of collaboration among } \\
\text { agencies/departments }\end{array}$ & 1 & & 2 & $\square$ \\
\hline d) & $\begin{array}{l}\text { Inappropriate and insufficient } \\
\text { sanctions for criminals }\end{array}$ & 1 & & 2 & $\square$ \\
\hline e) & Insufficient budget & 1 & & 2 & $\square$ \\
\hline f) & 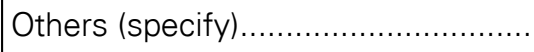 & 1 & & 2 & $\square$ \\
\hline D03 & $\begin{array}{l}\text { Do you think that you can } \\
\text { help the victims of violence } \\
\text { with the following? }\end{array}$ & Yes & No & $\begin{array}{c}\text { Do not } \\
\text { know/ No } \\
\text { answer }\end{array}$ & \\
\hline a) & Medical knowledge / skills & 1 & 2 & 3 & $\square$ \\
\hline b) & Spiritual support / counseling & 1 & 2 & 3 & $\square$ \\
\hline c) & Others (specify)... & 1 & 2 & 3 & $\square$ \\
\hline D04 & $\begin{array}{l}\text { Do you think that in } \\
\text { addition to professional } \\
\text { responsibilities, HCPs should } \\
\text { take the responsibility for } \\
\text { providing victims of violence } \\
\text { with other support (spiritual, } \\
\text { social, etc..)? } \\
\quad 1=\text { Yes } \\
2=\text { No }\end{array}$ & & & & $\square$ \\
\hline
\end{tabular}




\begin{tabular}{|c|c|c|c|c|c|}
\hline $\begin{array}{c}\text { D05 } \\
\text { A }\end{array}$ & $\begin{array}{l}\text { Have you participated in any } \\
\text { training courses/workshops } \\
\text { (official or unofficial) with } \\
\text { topics related to violence } \\
\text { against women in the last } 2 \\
\text { years? } \\
\quad 1=\text { Yes } \\
2=\text { Not yet }\end{array}$ & & & & $\square$ \\
\hline $\begin{array}{c}\text { D05 } \\
\text { B }\end{array}$ & $\begin{array}{l}\text { How many times? } \\
\text { Where? }\end{array}$ & & & & $\square$ \\
\hline D06 & $\begin{array}{l}\text { Would you like to participate } \\
\text { in any training on this topic } \\
\text { in the future? } \\
\begin{array}{l}1=\text { Yes } \\
2=\mathrm{No}--->\text { Move to Do8 }\end{array} \\
\end{array}$ & & & & \\
\hline Do7 & $\begin{array}{l}\text { Which areas would you like } \\
\text { to be trained on? } \\
\text { (Do not read, ask "which } \\
\text { topics/skills...?") }\end{array}$ & Yes & No & $\begin{array}{l}\text { Do not } \\
\text { know/ } \\
\text { No } \\
\text { answer }\end{array}$ & \\
\hline a) & $\begin{array}{l}\text { How to identify a female patient as } \\
\text { the victim of violence }\end{array}$ & 1 & 2 & 3 & $\square$ \\
\hline b) & $\begin{array}{l}\text { Methods of intervention (assess } \\
\text { patients' safety, provide information, } \\
\text { support empowerment, etc.) }\end{array}$ & 1 & 2 & 3 & $\square$ \\
\hline c) & $\begin{array}{l}\text { Referral agencies/public } \\
\text { organizations that can provide } \\
\text { support to the victims of violence }\end{array}$ & 1 & 2 & 3 & $\square$ \\
\hline d) & $\begin{array}{l}\text { Health, mental, and psychological } \\
\text { consequences }\end{array}$ & 1 & 2 & 3 & $\square$ \\
\hline e) & $\begin{array}{l}\text { Skills on counseling the victims of } \\
\text { violence }\end{array}$ & 1 & 2 & 3 & $\square$ \\
\hline f) & $\begin{array}{l}\text { General information on violence } \\
\text { against women (national and } \\
\text { international) }\end{array}$ & 1 & 2 & 3 & $\square$ \\
\hline g) & $\begin{array}{l}\text { Legal issues relating to violence } \\
\text { against women }\end{array}$ & 1 & 2 & 3 & $\square$ \\
\hline h) & 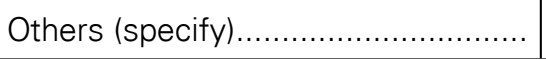 & 1 & 2 & 3 & $\square$ \\
\hline D08 & $\begin{array}{l}\text { Do you think that it is } \\
\text { necessary to have specific } \\
\text { treatment protocol/guidelines } \\
\text { on services for female } \\
\text { victims of violence? } \\
\quad 1=\text { Yes } \\
\quad 2=\mathrm{No}\end{array}$ & & & & \begin{tabular}{|l|l|} 
\\
\end{tabular} \\
\hline
\end{tabular}




\begin{tabular}{|c|c|c|c|c|}
\hline Do9 & $\begin{array}{l}\text { In your opinion, which } \\
\text { measures might help to } \\
\text { improve the situation of } \\
\text { violence against women? } \\
\text { (Do not read, ask "which } \\
\text { measures...?") }\end{array}$ & Mentioned & Not mentioned & \\
\hline a) & $\begin{array}{l}\text { Collaboration among agencies/ } \\
\text { public organizations (women's } \\
\text { union, youth's union, etc.) }\end{array}$ & 1 & 2 & $\square$ \\
\hline b) & Education for men on this issue & 1 & 2 & $\square$ \\
\hline c) & Strict penalties for perpetrators & 1 & 2 & $\square$ \\
\hline d) & Public education on gender equality & 1 & 2 & $\square$ \\
\hline e) & $\begin{array}{l}\text { Support women in recognizing } \\
\text { their important roles and rights } \\
\text { (empowerment) }\end{array}$ & 1 & 2 & $\square$ \\
\hline f) & Others (specify)... & 1 & 2 & $\square$ \\
\hline
\end{tabular}

THANK YOU 


\title{
Appendix 3:
}

1) Population Council

MINISTRY OF HEALTH

FORD FOUNDATION

HA NOI HEALTH DEPARTMENT

\section{IMPROVING QUALITY OF HEALTH CARE FOR GENDER-BASED VIOLENCE VICTIMS AT HEALTH FACILITIES IN VIET NAM}

\author{
PRE-TRAINING ASSESSMENT
}

\section{Questionnaire for Health Care Providers}

(PRE-TRAINING ASSESSMENT IN DA NANG \& HCMC)

ID

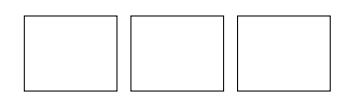

\section{Population Council}

41 Le Hong Phong - Ha Noi

Tel: 0437345821

Fax : 04-373 45827 


\section{PROJECT: IMPROVING QUALITY OF HEALTH CARE FOR GENDER-BASED VIOLENCE VICTIMS AT HEALTH FACILITIES IN VIET NAM}

\section{Instruction:}

We are collecting information about the experience and perspectives of health care providers ( $\mathrm{HCPs}^{\prime}$ ) regarding an integrated screening for gender based violence (GBV). Although both men and women can be victims of violence, this survey focuses on women who are victims of violence. Even if you have never treated a victim of violence in your practice, your response will still be very helpful to us. The findings from this survey will be used for

developing materials to improve the health care service for detecting and treating GBV victims.

Please do not write your name on the questionnaire. It is important to note that the purpose of this survey is not to evaluate your performance; for this reason, we ask you to give an honest answer. Your answers will be treated confidentially and will not affect your work or your position in any way.

\section{A. GENERAL INFORMATION}

\section{A01. Name of employer:}

A02. What is your job in the hospital? (Please circle the correct answer)
1. Doctor
2. Assistant Doctor
3. Midwife
4. Nurse
5. Other (specify)
A03. What is your gender?
1. Male
2. Female

\section{A04. In which departments do you work?}

1. Pediatrics

2. Obstetrics and Gynecology

3. Internal Medicine Clinic

4. Emergency \& Intensive Care

5. Traumatology

6. Medical Imaging

7. Internal Medicine

8. Operating and Anesthesia

9. Accounting

10. General Surgery

11. Admin and Personnel
12. Pharmacy

13. Laboratory

14. Otolaryngology

15. General Department

16. Surgery Clinic

17. Ophthalmology

18. Somato-Dental-and Facial

19. Admin and Personnel

20. Director Board

21. Other (specify) 
A05. How long have you been working in this hospital? (to round up) (years)

(Less than 12 months $=1$ year)

A06. How long have you been working in the health sector (to round up)........... (years)

(Less than 12 months $=1$ year)

A07. How old are you? 1 year)

A08. What is your marital status?
1. Single
2. Married
3. Separated
4. Divorced
5. Widowed

A09. How many living children do you have?

Number of children.

A10. What is your religion?
1. None
2. Buddhism
3. Christian
4. Other (specify)

A11. What is your ethnicity?
1. Kinh
2. Other (specify)

A12. Do you have any experience in training in general?
a. I have no experience in training
b. I have less than 1 year of experience in training
c. I have between 1 to 2 years of experience in training
d. I have more than 2 years of experience in training

A13. What do you expect from this TOT? 


\section{B. PERCEPTION AND KNOWLEDGE OF VIOLENCE AGAINST WOMEN}

B01. People may have different views of the behaviors between spouses in a family. To what extent, do you agree or disagree with the following type of behaviors?

\begin{tabular}{|l|l|c|c|c|c|c|}
\hline \multicolumn{9}{|c|}{ Please circle only one option between 1 and 5} \\
\hline & $\begin{array}{c}\text { Strongly } \\
\text { disagree }\end{array}$ & Disagree & $\begin{array}{c}\text { Neither } \\
\text { agree } \\
\text { nor } \\
\text { disagree }\end{array}$ & Agree & $\begin{array}{c}\text { Strongly } \\
\text { agree }\end{array}$ \\
\hline a) & $\begin{array}{l}\text { The husband should } \\
\text { demonstrate to his spouse } \\
\text { that he is the “boss" of the } \\
\text { family }\end{array}$ & 1 & 2 & 3 & 4 & 5 \\
\hline b) & $\begin{array}{l}\text { A good wife should listen } \\
\text { to her spouse even if she } \\
\text { disagrees with his opinions or } \\
\text { behaviors }\end{array}$ & 1 & 2 & 3 & 4 & 5 \\
\hline c) & $\begin{array}{l}\text { A woman is responsible for } \\
\text { satisfying her husband's } \\
\text { sexual demand even when } \\
\text { she doesn't want to }\end{array}$ & 1 & 2 & 3 & 4 & 5 \\
\hline & $\begin{array}{l}\text { Domestic conflicts should be } \\
\text { solved within the family (it's } \\
\text { better not to wash one's dirty } \\
\text { linen in public) }\end{array}$ & 1 & 2 & 3 & 4 & 5 \\
\hline e) & $\begin{array}{l}\text { There should be external } \\
\text { interventions if a man always } \\
\text { beats his wife }\end{array}$ & 1 & 2 & 3 & 4 & 5 \\
\hline
\end{tabular}

B02. In your opinion, do you agree or disagree with the following statements about the husband's right to beat his wife if she:

\begin{tabular}{|l|l|c|c|c|c|c|}
\hline & $\begin{array}{c}\text { Strongly } \\
\text { disagree }\end{array}$ & Disagree & $\begin{array}{c}\text { Neither } \\
\text { agree } \\
\text { nor } \\
\text { disagree }\end{array}$ & Agree & $\begin{array}{c}\text { Strongly } \\
\text { agree }\end{array}$ \\
\hline a) $\begin{array}{l}\text { Does not fulfill the domestic } \\
\text { duties as expected by her } \\
\text { husband (i.e. laziness, } \\
\text { wastefulness, not taking } \\
\text { care of the children, etc.) }\end{array}$ & 1 & 2 & 3 & 4 & 5 \\
\hline b) & $\begin{array}{l}\text { Is addicted to gambling and } \\
\text { drugs }\end{array}$ & 1 & 2 & 3 & 4 & 5 \\
\hline
\end{tabular}




\begin{tabular}{|c|l|c|c|c|c|c|}
\hline c) & $\begin{array}{l}\text { Contradicts her husband's } \\
\text { opinions }\end{array}$ & 1 & 2 & 3 & 4 & 5 \\
\hline d) & $\begin{array}{l}\text { Insults and abuses her } \\
\text { spouse }\end{array}$ & 1 & 2 & 3 & 4 & 5 \\
\hline e) & $\begin{array}{l}\text { Does not satisfy her } \\
\text { husband's sexual demand }\end{array}$ & 1 & 2 & 3 & 4 & 5 \\
\hline f) & Has extra-marital relations & 1 & 2 & 3 & 4 & 5 \\
\hline g) & Others (specify)................. & 1 & 2 & 3 & 4 & 5 \\
\hline
\end{tabular}

\section{B03. In your opinion, do you agree or disagree with the following statements} about a woman's right to refuse having sex with her spouse when:

\begin{tabular}{|l|l|c|c|c|c|c|}
\hline & $\begin{array}{c}\text { Strongly } \\
\text { disagree }\end{array}$ & Disagree & $\begin{array}{c}\text { Neither } \\
\text { agree nor } \\
\text { disagree }\end{array}$ & Agree & $\begin{array}{c}\text { Strongly } \\
\text { agree }\end{array}$ \\
\hline a) & $\begin{array}{l}\text { She does not want to } \\
\text { (without specific reasons) }\end{array}$ & 1 & 2 & 3 & 4 & 5 \\
\hline b) & She is tired & 1 & 2 & 3 & 4 & 5 \\
\hline c) & Her husband is drunk & 1 & 2 & 3 & 4 & 5 \\
\hline d) & $\begin{array}{l}\text { Her husband treats her } \\
\text { violently }\end{array}$ & 1 & 2 & 3 & 4 & 5 \\
\hline e) & Others (specify)................. & 1 & 2 & 3 & 4 & 5 \\
\hline
\end{tabular}

\section{B04. In your opinion, do you agree or disagree that the following acts} represent acceptable behaviors towards women?

\begin{tabular}{|l|l|c|c|c|c|c|}
\hline & $\begin{array}{c}\text { Strongly } \\
\text { disagree }\end{array}$ & Disagree & $\begin{array}{c}\text { Neither } \\
\text { agree nor } \\
\text { disagree }\end{array}$ & Agree & $\begin{array}{c}\text { Strongly } \\
\text { agree }\end{array}$ \\
\hline a) & $\begin{array}{l}\text { Assaulting and hurting } \\
\text { women (i.e. smacking, } \\
\text { cuffing, or punching) }\end{array}$ & 1 & 2 & 3 & 4 & 5 \\
\hline b) $\begin{array}{l}\text { Beating women when they } \\
\text { are pregnant }\end{array}$ & 1 & 2 & 3 & 4 & 5 \\
\hline c) & $\begin{array}{l}\text { Using sticks, canes or } \\
\text { dangerous tools (such as } \\
\text { knife) to attack women }\end{array}$ & 1 & 2 & 3 & 4 & 5 \\
\hline d) & $\begin{array}{l}\text { Insulting, abusing, } \\
\text { humiliating women and } \\
\text { making them feel ashamed }\end{array}$ & 1 & 2 & 3 & 4 & 5 \\
\hline e) & Throwing women out of home & 1 & 2 & 3 & 4 & 5 \\
\hline
\end{tabular}




\begin{tabular}{|c|c|c|c|c|c|c|}
\hline f) & $\begin{array}{l}\text { Abandoning, not taking care of } \\
\text { the women's work and health }\end{array}$ & 1 & 2 & 3 & 4 & 5 \\
\hline g) & $\begin{array}{l}\text { Threatening, controlling } \\
\text { (using knife, arms, economic } \\
\text { means or children as the } \\
\text { tools to control women or } \\
\text { threaten to divorce) }\end{array}$ & 1 & 2 & 3 & 4 & 5 \\
\hline h) & $\begin{array}{l}\text { Preventing women from } \\
\text { participating in social } \\
\text { activities/working/studying }\end{array}$ & 1 & 2 & 3 & 4 & 5 \\
\hline i) & $\begin{array}{l}\text { Preventing women from } \\
\text { connecting to their families/ } \\
\text { friends }\end{array}$ & 1 & 2 & 3 & 4 & 5 \\
\hline j) & $\begin{array}{l}\text { Preventing women from } \\
\text { getting health services or } \\
\text { taking medicines when they } \\
\text { are sick }\end{array}$ & 1 & 2 & 3 & 4 & 5 \\
\hline k) & $\begin{array}{l}\text { Forcing women to have } \\
\text { more babies }\end{array}$ & 1 & 2 & 3 & 4 & 5 \\
\hline l) & $\begin{array}{l}\text { Preventing women from } \\
\text { using contraceptive } \\
\text { methods }\end{array}$ & 1 & 2 & 3 & 4 & 5 \\
\hline m) & $\begin{array}{l}\text { Forcing to have sexual } \\
\text { intercourse when his wife } \\
\text { doesn't want to }\end{array}$ & 1 & 2 & 3 & 4 & 5 \\
\hline n) & $\begin{array}{l}\text { Having extra-marital } \\
\text { relationships }\end{array}$ & 1 & 2 & 3 & 4 & 5 \\
\hline o) & Others (specify) ....................... & 1 & 2 & 3 & 4 & 5 \\
\hline
\end{tabular}

\section{B05. Can you please list at least 5 causes that lead to GBV?}
a.
b.
C.
d.
e.

\section{B06. Can you please list at least 5 consequences of GBV?}
a.
b.
C.
d.
e. 


\section{ROLE OF HEALTH CARE PROVIDER}

C1. In the past, under which of the following circumstances did you ask a direct question about GBV? (Select one answer for each of the following circumstances)

a. Did you ask because a client presented bruises or other signs of violence:
1. Yes
2. No
3. Not applicable

If Yes, how often in the past years did you ask about possible GBV in this circumstance:
1. Once
2. Several times
3. Often

b. Did you ask because a client said something that made you suspect violence:
1. Yes
2. No
3. Not applicable

If Yes, how often in the past years did you ask about violence under this circumstance:
1. Once
2. Several times
3. Often

c. Did you ask as a matter of routine (for example, as part of asking for clinical history):
1. Yes
2. No
3. Not applicable

If Yes, how often in the past years did you ask about possible GBV under this circumstance:
1. Once
2. Several times
3. Often

d. Did you ask because of economic constraints mentioned?
1. Yes
2. No
3. Not applicable

If Yes, how often in the past years did you ask about possible GBV under this circumstance:
1. Once
2. Several times
3. Often

C2. There may be barriers that make it difficult to ask women about violence. In your own experience, to what extent do you think the following barriers make it difficult for you to ask women about GBV.

\begin{tabular}{|l|l|c|c|c|c|}
\hline & & $\begin{array}{c}\text { Not a } \\
\text { barrier } \\
\text { at all }\end{array}$ & $\begin{array}{c}\text { Minor } \\
\text { barrier }\end{array}$ & $\begin{array}{c}\text { Moderate } \\
\text { barrier }\end{array}$ & $\begin{array}{c}\text { Major } \\
\text { barrier }\end{array}$ \\
\hline a) & I have time limitations & 1 & 2 & 3 & 4 \\
\hline b) $\begin{array}{l}\text { There is lack of private space in the } \\
\text { clinic }\end{array}$ & 1 & 2 & 3 & 4 \\
\hline c) & $\begin{array}{l}\text { There are few opportunities to speak } \\
\text { with women on one to one basis }\end{array}$ & 1 & 2 & 3 & 4 \\
\hline
\end{tabular}




\begin{tabular}{|c|l|c|c|c|c|}
\hline d) & $\begin{array}{l}\text { I feel there is little I can do to help } \\
\text { them }\end{array}$ & 1 & 2 & 3 & 4 \\
\hline e) & $\begin{array}{l}\text { There are few resources in the } \\
\text { community where I could refer GBV } \\
\text { victims }\end{array}$ & 1 & 2 & 3 & 4 \\
\hline f) & $\begin{array}{l}\text { I could offend women if I ask them } \\
\text { directly about GBV }\end{array}$ & 1 & 2 & 3 & 4 \\
\hline g) & $\begin{array}{l}\text { Differences in culture beliefs and } \\
\text { values make it difficult to ask about } \\
\text { violence }\end{array}$ & 1 & 2 & 3 & 4 \\
\hline h) & $\begin{array}{l}\text { I need to focus my attention on other } \\
\text { health problems that have a higher } \\
\text { priority }\end{array}$ & 1 & 2 & 3 & 4 \\
\hline i) & $\begin{array}{l}\text { Getting involved in cases of violence } \\
\text { means that I have to participate in } \\
\text { police proceedings }\end{array}$ & 1 & 2 & 3 & 4 \\
\hline j) & $\begin{array}{l}\text { I could provoke retaliation from } \\
\text { abuser }\end{array}$ & 1 & 2 & 3 & 4 \\
\hline k) & $\begin{array}{l}\text { I have not received enough training } \\
\text { to address the issues of violence }\end{array}$ & 1 & 2 & 3 & 4 \\
\hline I) & $\begin{array}{l}\text { There is lack of law and regulations } \\
\text { that I could base on }\end{array}$ & 1 & 2 & 3 & 4 \\
\hline m) & Others (specify)........................... & 1 & 2 & 3 & 4 \\
\hline
\end{tabular}

\section{C3. Is there any law in Viet Nam that addresses domestic violence?}
1. No
2. Yes
3. Do not know

If yes, can you list any law in Viet Nam that addresses domestic violence?

\section{C4. According to the law in Viet Nam, do health care providers have any legal obligation to treat victims of GBV?}
1. No
2. Yes
3. Do not know

If yes, what are legal obligations of the health care providers? 
C5. Do you think health care providers should routinely ask patients questions about possible GBV?
1. No
2. Yes
3. Do not know

If yes, why?

C6. Can you name at least two organizations that offer help or other services to women living in violent situations or having experienced GBV?

C7. In your clinic, is there a directory or written list of local organizations or other community resources to which you can refer women victims of GBV for further help?

1. No 2. Yes

If yes, have you ever used the directory/list?

1. Yes

3. Do not know

2. No

C8. To what extent, do you agree or disagree with the following statements about health care providers' responsibility to the GBV issues?

\begin{tabular}{|l|l|c|c|c|c|c|}
\hline \multicolumn{9}{|c|}{ Please circle one option between 1 to 5 for each row from a to e } \\
\hline & $\begin{array}{c}\text { Strongly } \\
\text { disagree }\end{array}$ & Disagree & $\begin{array}{c}\text { Neither } \\
\text { agree } \\
\text { nor } \\
\text { disagree }\end{array}$ & Agree & $\begin{array}{c}\text { Strongly } \\
\text { agree }\end{array}$ \\
\hline a) & $\begin{array}{l}\text { HCPs have responsibility to ask } \\
\text { about physical violence }\end{array}$ & 1 & 2 & 3 & 4 & 5 \\
\hline b) & $\begin{array}{l}\text { HCPs have responsibility to ask } \\
\text { about sexual violence }\end{array}$ & 1 & 2 & 3 & 4 & 5 \\
\hline c) & $\begin{array}{l}\text { HCPs have responsibility to ask } \\
\text { about psychological violence }\end{array}$ & 1 & 2 & 3 & 4 & 5 \\
\hline d) & $\begin{array}{l}\text { HCPs have responsibility to ask } \\
\text { about economic violence }\end{array}$ & 1 & 2 & 3 & 4 & 5 \\
\hline & $\begin{array}{l}\text { HCPs have as much } \\
\text { responsibility to ask about } \\
\text { violence as they do to ask } \\
\text { about other causes of health } \\
\text { problems }\end{array}$ & 1 & 2 & 3 & 4 & 5 \\
\hline
\end{tabular}




\section{C9. Health providers can respond to victims of violence in many different ways. In the past years, how often did you do each of the following actions?}

\begin{tabular}{|c|l|c|c|c|c|}
\hline \multicolumn{5}{|c|}{ Please circle one option between 1 to 4} \\
\hline & \multicolumn{1}{|c|}{ Never } & Once & $\begin{array}{c}\text { Several } \\
\text { times }\end{array}$ & $\begin{array}{c}\text { Many } \\
\text { times }\end{array}$ \\
\hline a) & $\begin{array}{l}\text { I identify or suspect that a client has } \\
\text { been harmed or abused }\end{array}$ & 1 & 2 & 3 & 4 \\
\hline b) & $\begin{array}{l}\text { I listen to and provide emotional support } \\
\text { to the victim }\end{array}$ & 1 & 2 & 3 & 4 \\
\hline c) & I document information about GBV cases & 1 & 2 & 3 & 4 \\
\hline d) & $\begin{array}{l}\text { I inform a client about her right with } \\
\text { respect to protection from GBV }\end{array}$ & 1 & 2 & 3 & 4 \\
\hline e) & $\begin{array}{l}\text { I inform a client about referral service for } \\
\text { counseling }\end{array}$ & 1 & 2 & 3 & 4 \\
\hline f) & $\begin{array}{l}\text { I inform a client about referral service for } \\
\text { legal assistance }\end{array}$ & 1 & 2 & 3 & 4 \\
\hline g) & $\begin{array}{l}\text { I inform a client about other supporting } \\
\text { services in the community }\end{array}$ & 1 & 2 & 3 & 4 \\
\hline h) & $\begin{array}{l}\text { I assess the level of danger that a patient } \\
\text { is facing }\end{array}$ & 1 & 2 & 3 & 4 \\
\hline i) & $\begin{array}{l}\text { I help the patient in a dangerous situation } \\
\text { to establish a safety plan }\end{array}$ & 1 & 2 & 3 & 4 \\
\hline j) & $\begin{array}{l}\text { I inform a client about the effects of } \\
\text { violence on health and about other risk } \\
\text { that she faces }\end{array}$ & 1 & 2 & 3 & 4 \\
\hline k) & Other (specify)................................ & 1 & 2 & 3 & 4 \\
\hline
\end{tabular}

\section{C10. How well trained/prepared do you feel to...}

\begin{tabular}{|l|l|c|c|c|}
\hline \multicolumn{5}{|c|}{ Please circle one option between 1 to 3} \\
\hline & $\begin{array}{c}\text { Not adequately } \\
\text { trained or } \\
\text { prepared }\end{array}$ & $\begin{array}{c}\text { More or less } \\
\text { trained or } \\
\text { prepared }\end{array}$ & $\begin{array}{c}\text { Sufficiently } \\
\text { trained or } \\
\text { prepared }\end{array}$ \\
\hline a) & $\begin{array}{l}\text { Talk with women about gender } \\
\text { based violence }\end{array}$ & 1 & 2 & 3 \\
\hline b) & $\begin{array}{l}\text { Detect cases of physical } \\
\text { domestic violence }\end{array}$ & 1 & 2 & 3 \\
\hline c) & $\begin{array}{l}\text { Detect cases of psychological } \\
\text { violence }\end{array}$ & 1 & 2 & 3 \\
\hline d) & Detect cases of sexual violence & 1 & 2 & 3 \\
\hline
\end{tabular}




\begin{tabular}{|c|c|c|c|c|}
\hline e) & $\begin{array}{l}\text { Detect cases of economic } \\
\text { violence }\end{array}$ & 1 & 2 & 3 \\
\hline f) & $\begin{array}{l}\text { Identify clients with a history of } \\
\text { sexual abuse during childhood }\end{array}$ & 1 & 2 & 3 \\
\hline g) & $\begin{array}{l}\text { Provide care to victims of gender } \\
\text { based violence }\end{array}$ & 1 & 2 & 3 \\
\hline h) & $\begin{array}{l}\text { Assess the level of danger of a } \\
\text { woman living in a violent situation }\end{array}$ & 1 & 2 & 3 \\
\hline i) & Help client to create a safety plan & 1 & 2 & 3 \\
\hline j) & Document cases of violence & 1 & 2 & 3 \\
\hline k) & $\begin{array}{l}\text { Record details about a case of } \\
\text { violence in a clinical history form }\end{array}$ & 1 & 2 & 3 \\
\hline I) & $\begin{array}{l}\text { Provide information to affected } \\
\text { clients }\end{array}$ & 1 & 2 & 3 \\
\hline m) & $\begin{array}{l}\text { Provide referrals to victims of } \\
\text { gender based violence }\end{array}$ & 1 & 2 & 3 \\
\hline n) & $\begin{array}{l}\text { Counsel women about } \\
\text { emergency contraception }\end{array}$ & 1 & 2 & 3 \\
\hline o) & $\begin{array}{l}\text { Address the reproductive health } \\
\text { needs of women who have } \\
\text { suffered sexual violence }\end{array}$ & 1 & 2 & 3 \\
\hline
\end{tabular}

\section{C11. As a health care provider, in a scale from 1 to 5 , please indicate your knowledge about the following issues you may face when working with GBV victims.}

\section{Please circle one option for each items from $1-5$ 1 = No knowledge at all, 5 = Very knowledgeable}

\begin{tabular}{|l|l|c|c|c|c|c|}
\hline a) & $\begin{array}{l}\text { Role of HCP in dealing with GBV } \\
\text { victims }\end{array}$ & 1 & 2 & 3 & 4 & 5 \\
\hline b) & $\begin{array}{l}\text { HCP responsibility required by Law } \\
\text { on Domestic Violence Prevention and } \\
\text { Control (2007) }\end{array}$ & 1 & 2 & 3 & 4 & 5 \\
\hline c) & Procedure to work with GBV victims & 1 & 2 & 3 & 4 & 5 \\
\hline d) & $\begin{array}{l}\text { Screening and response of HCPs to } \\
\text { GBV }\end{array}$ & 1 & 2 & 3 & 4 & 5 \\
\hline e) & GBV screening protocol & 1 & 2 & 3 & 4 & 5 \\
\hline f) & Management of GBV victims & 1 & 2 & 3 & 4 & 5 \\
\hline g) & Providing counseling for GBV victims & 1 & 2 & 3 & 4 & 5 \\
\hline
\end{tabular}




\begin{tabular}{|c|l|c|c|c|c|c|}
\hline h) & Dealing with perpetrator & 1 & 2 & 3 & 4 & 5 \\
\hline i) & $\begin{array}{l}\text { Required resources for health care } \\
\text { facility to provide treatment and } \\
\text { support for GBV victims }\end{array}$ & 1 & 2 & 3 & 4 & 5 \\
\hline j) & $\begin{array}{l}\text { Information about the setting up of } \\
\text { the counseling center to support GBV } \\
\text { women at health care facility }\end{array}$ & 1 & 2 & 3 & 4 & 5 \\
\hline
\end{tabular}

\section{TRAINING ON GBV}

D1. In the past two years, how many times have you participated in training session regarding GBV?.

\section{D2. Regarding these trainings, which organization provided them?}

\begin{tabular}{|c|c|c|c|}
\hline 1 & Organizations & Years & Topic \\
\hline 2 & & & \\
\hline 3 & & & \\
\hline
\end{tabular}

D3. On which of the following topics related to GBV would you like to receive training? (Please circle options that you would like to receive)

a. Indicator of violence

b. How to ask questions to GBV victims

c. How to conduct a clinical exam

d. How to provide service to GBV victims

e. Referral options

f. Health effects

g. Legal issues

h. Others (specify).

i. None 


\title{
Appendix 4:
}

\section{IMPROVING QUALITY OF HEALTH CARE FOR GENDER-BASED VIOLENCE VICTIMS AT HEALTH FACILITIES IN VIET NAM}

\author{
POST-TRAINING ASSESSMENT
}

\section{Questionnaire for Health Care Providers}

(POST-TRAINING ASSESSMENT IN DA NANG \& HCMC)

ID

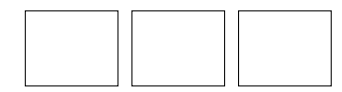

\section{Population Council}

41 Le Hong Phong - Ha Noi

Tel: 0437345821

Fax : 04-373 45827 


\section{PROJECT: IMPROVING QUALITY OF HEALTH CARE FOR GENDER-BASED VIOLENCE VICTIMS AT HEALTH FACILITIES IN VIET NAM}

\section{Instructions:}

We are collecting information about the experience and perspectives of health care providers (HCPs) regarding and integrated screening for gender based violence (GBV). Although both men and women can be victims of violence, this survey focuses on women who are victims of violence. Even if you have never treated a victim of violence in your practice, your response will still be very helpful to us. The findings from this survey will be used for developing materials to improve the health care service for detecting and treating GBV victims.

Please do not write your name on the questionnaire. It is important to note that the purpose of this survey is not to evaluate your performance; for this reason, we ask you to give an honest answer. Your answers will be treated confidentially and will not affect your work or your position in any way.

\section{A. GENERAL INFORMATION}

A01. Name of employer:

A02. What is your job in the hospital? (Please circle the correct answer)
1. Doctor
2. Assistant doctor
3. Midwife
4. Nurse
5. Other (specify)
A03. What is your gender?
1. Male
2. Female

\section{A04. In which departments do you work?}

1. Pediatrics

2. Obstetrics and Gynecology

3. Internal Medicine Clinic

4. Emergency \& Intensive Care

5. Traumatology

6. Medical Imaging

7. Internal Medicine

8. Operating and Anesthesia

9. Accounting

10. General Surgery

11. Admin and Personnel
12. Pharmacy

13. Laboratory

14. Otolaryngology

15. General Department

16. Surgery Clinic

17. Ophthalmology

18. Somato-Dental-and Facial

19. Admin and Personnel

20. Director board

21. Other (specify) 
A05. How long have you been working in this hospital? (to round up) (years)

(Less than 12 months $=1$ year)

A06. How long have you been working in the health sector (to round up) (years)

(Less than 12 months $=1$ year)

A07. How old are you? 1 year) years (please round up, less than 12 months =

A08. What is your marital status?
1. Single
2. Married
3. Separated
4. Divorced
5. Widowed

A09. How many living children do you have?

Number of children.

A10. What is your religion?
1. None
2. Buddhism
3. Christian
4. Other (specify)

A11. What is your ethnicity?
1. Kinh
2. Other (specify)

A12. Do you have any experience in training in general?
a. I have no experience in training
b. I have less than 1 year of experience in training
c. I have between 1 to 2 years of experience in training
d. I have more than 2 years of experience in training

A13. What do you expect from this TOT? 


\section{B. PERCEPTION AND KNOWLEDGE OF VIOLENCE AGAINST WOMEN}

B01. People may have different views of the behaviors between spouses in a family. To what extent, do you agree or disagree with the following type of behaviors?

\begin{tabular}{|l|l|c|c|c|c|c|}
\hline \multicolumn{9}{|c|}{ Please circle only one option between 1 and 5} \\
\hline & $\begin{array}{c}\text { Strongly } \\
\text { disagree }\end{array}$ & Disagree & $\begin{array}{c}\text { Neither } \\
\text { agree } \\
\text { nor } \\
\text { disagree }\end{array}$ & Agree & $\begin{array}{c}\text { Strongly } \\
\text { agree }\end{array}$ \\
\hline a) & $\begin{array}{l}\text { The husband should } \\
\text { demonstrate to his spouse } \\
\text { that he is the “boss" of the } \\
\text { family }\end{array}$ & 1 & 2 & 3 & 4 & 5 \\
\hline b) & $\begin{array}{l}\text { A good wife should listen } \\
\text { to her spouse even if she } \\
\text { disagrees with his opinions or } \\
\text { behaviors }\end{array}$ & 1 & 2 & 3 & 4 & 5 \\
\hline c) & $\begin{array}{l}\text { A woman is responsible for } \\
\text { satisfying her husband's } \\
\text { sexual demand even when } \\
\text { she doesn't want to }\end{array}$ & 1 & 2 & 3 & 4 & 5 \\
\hline d) & $\begin{array}{l}\text { Domestic conflicts should be } \\
\text { solved within the family (it's } \\
\text { better not to wash one's dirty } \\
\text { linen in public) }\end{array}$ & 1 & 2 & 3 & 4 & 5 \\
\hline e) & $\begin{array}{l}\text { There should be external } \\
\text { interventions if a man always } \\
\text { beats his wife }\end{array}$ & 1 & 2 & 3 & 4 & 5 \\
\hline
\end{tabular}

B02. In your opinion, do you agree or disagree with the following statements about the husband's right to beat his wife if she:

\begin{tabular}{|l|l|c|c|c|c|c|}
\hline & $\begin{array}{c}\text { Strongly } \\
\text { disagree }\end{array}$ & Disagree & $\begin{array}{c}\text { Neither } \\
\text { agree } \\
\text { nor } \\
\text { disagree }\end{array}$ & Agree & $\begin{array}{c}\text { Strongly } \\
\text { agree }\end{array}$ \\
\hline a) & $\begin{array}{l}\text { Does not fulfill the domestic } \\
\text { duties as expected by her } \\
\text { husband (i.e. laziness, } \\
\text { wastefulness, not taking care } \\
\text { of the children, etc.) }\end{array}$ & 1 & 2 & 3 & 4 & 5 \\
\hline b) & $\begin{array}{l}\text { Is addicted to gambling and } \\
\text { drugs }\end{array}$ & 1 & 2 & 3 & 4 & 5 \\
\hline
\end{tabular}




\begin{tabular}{|c|l|c|c|c|c|c|}
\hline c) & $\begin{array}{l}\text { Contradicts her husband's } \\
\text { opinions }\end{array}$ & 1 & 2 & 3 & 4 & 5 \\
\hline d) & $\begin{array}{l}\text { Insults and abuses her } \\
\text { spouse }\end{array}$ & 1 & 2 & 3 & 4 & 5 \\
\hline e) & $\begin{array}{l}\text { Does not satisfy her } \\
\text { husband's sexual demand }\end{array}$ & 1 & 2 & 3 & 4 & 5 \\
\hline f) & Has extra-marital relations & 1 & 2 & 3 & 4 & 5 \\
\hline g) & Others (specify).................... & 1 & 2 & 3 & 4 & 5 \\
\hline
\end{tabular}

\section{B03. In your opinion, do you agree or disagree with the following statements} about a woman's right to refuse having sex with her spouse when:

\begin{tabular}{|l|l|c|c|c|c|c|}
\hline & $\begin{array}{c}\text { Strongly } \\
\text { disagree }\end{array}$ & Disagree & $\begin{array}{c}\text { Neither } \\
\text { agree nor } \\
\text { disagree }\end{array}$ & Agree & $\begin{array}{c}\text { Strongly } \\
\text { agree }\end{array}$ \\
\hline a) & $\begin{array}{l}\text { She does not want to } \\
\text { (without specific reasons) }\end{array}$ & 1 & 2 & 3 & 4 & 5 \\
\hline b) & She is tired & 1 & 2 & 3 & 4 & 5 \\
\hline c) & Her husband is drunk & 1 & 2 & 3 & 4 & 5 \\
\hline d) & $\begin{array}{l}\text { Her husband treats her } \\
\text { violently }\end{array}$ & 1 & 2 & 3 & 4 & 5 \\
\hline e) & Others (specify).................. & 1 & 2 & 3 & 4 & 5 \\
\hline
\end{tabular}

\section{B04. In your opinion, do you agree or disagree that the following acts} represent acceptable behaviors towards women?

\begin{tabular}{|l|l|c|c|c|c|c|}
\hline & $\begin{array}{c}\text { Strongly } \\
\text { disagree }\end{array}$ & Disagree & $\begin{array}{c}\text { Neither } \\
\text { agree nor } \\
\text { disagree }\end{array}$ & Agree & $\begin{array}{c}\text { Strongly } \\
\text { agree }\end{array}$ \\
\hline a) & $\begin{array}{l}\text { Assaulting and hurting } \\
\text { women (i.e. smacking, } \\
\text { cuffing, or punching) }\end{array}$ & 1 & 2 & 3 & 4 & 5 \\
\hline b) & $\begin{array}{l}\text { Beating women when they } \\
\text { are pregnant }\end{array}$ & 1 & 2 & 3 & 4 & 5 \\
\hline c) & $\begin{array}{l}\text { Using sticks, canes or } \\
\text { dangerous tools (such as } \\
\text { knife) to attack women }\end{array}$ & 1 & 2 & 3 & 4 & 5 \\
\hline d) & $\begin{array}{l}\text { Insulting, abusing, } \\
\text { humiliating women and } \\
\text { making them feel ashamed }\end{array}$ & 1 & 2 & 3 & 4 & 5 \\
\hline e) & Throwing women out of home & 1 & 2 & 3 & 4 & 5 \\
\hline
\end{tabular}




\begin{tabular}{|c|c|c|c|c|c|c|}
\hline f) & $\begin{array}{l}\text { Abandoning, not taking care } \\
\text { of the women's work and } \\
\text { health }\end{array}$ & 1 & 2 & 3 & 4 & 5 \\
\hline g) & $\begin{array}{l}\text { Threatening, controlling } \\
\text { (using knife, arms, economic } \\
\text { means or children as the } \\
\text { tools to control women or } \\
\text { threaten to divorce) }\end{array}$ & 1 & 2 & 3 & 4 & 5 \\
\hline h) & $\begin{array}{l}\text { Preventing women from } \\
\text { participating in social } \\
\text { activities/working/studying }\end{array}$ & 1 & 2 & 3 & 4 & 5 \\
\hline i) & $\begin{array}{l}\text { Preventing women from } \\
\text { connecting to their families/ } \\
\text { friends }\end{array}$ & 1 & 2 & 3 & 4 & 5 \\
\hline j) & $\begin{array}{l}\text { Preventing women from } \\
\text { getting health services or } \\
\text { taking medicines when they } \\
\text { are sick }\end{array}$ & 1 & 2 & 3 & 4 & 5 \\
\hline k) & $\begin{array}{l}\text { Forcing women to have } \\
\text { more babies }\end{array}$ & 1 & 2 & 3 & 4 & 5 \\
\hline ।) & $\begin{array}{l}\text { Preventing women from } \\
\text { using contraceptive methods }\end{array}$ & 1 & 2 & 3 & 4 & 5 \\
\hline m) & $\begin{array}{l}\text { Forcing to have sexual } \\
\text { intercourse when his wife } \\
\text { doesn't want to }\end{array}$ & 1 & 2 & 3 & 4 & 5 \\
\hline n) & $\begin{array}{l}\text { Having extra-marital } \\
\text { relationships }\end{array}$ & 1 & 2 & 3 & 4 & 5 \\
\hline o) & Others (specify)...................... & 1 & 2 & 3 & 4 & 5 \\
\hline
\end{tabular}

\section{B05. Can you please list at least 5 causes that lead to GBV?}
a.
b.
C.
d.
e.

\section{B06. Can you please list at least 5 consequences of GBV?}
a.
b.
C.
d.
e. 


\section{ROLE OF HEALTH CARE PROVIDER}

C1. In the past, under which of the following circumstances did you ask a direct question about GBV? (Select one answer for each of the following circumstances)

a. Did you ask because a client presented bruises or other signs of violence:
1. Yes
2. No
3. Not applicable

If Yes, how often in the past years did you ask about possible GBV in this circumstance:
1. Once
2. Several times
3. Often

b. Did you ask because a client said something that made you suspect violence:
1. Yes
2. No
3. Not applicable

If Yes, how often in the past years did you ask about violence under this circumstance:
1. Once
2. Several times
3. Often

c. Did you ask as a matter of routine (for example, as part of asking for clinical history):
1. Yes
2. No
3. Not applicable

If Yes, how often in the past years did you ask about possible GBV under this circumstance:
1. Once
2. Several times
3. Often

d. Did you ask because of economic constraints mentioned?
1. Yes
2. No
3. Not applicable

If Yes, how often in the past years did you ask about possible GBV under this circumstance:
1. Once
2. Several times
3. Often

C2. There may be barriers that make it difficult to ask women about violence. In your own experience, to what extent do you think the following barriers make it difficult for you to ask women about GBV.

\begin{tabular}{|l|l|c|c|c|c|}
\hline & $\begin{array}{c}\text { Not a } \\
\text { barrier } \\
\text { at all }\end{array}$ & $\begin{array}{c}\text { Minor } \\
\text { barrier }\end{array}$ & $\begin{array}{c}\text { Moderate } \\
\text { barrier }\end{array}$ & $\begin{array}{c}\text { Major } \\
\text { barrier }\end{array}$ \\
\hline a) & I have time limitations & 1 & 2 & 3 & 4 \\
\hline b) & $\begin{array}{l}\text { There is lack of private space in the } \\
\text { clinic }\end{array}$ & 1 & 2 & 3 & 4 \\
\hline c) & $\begin{array}{l}\text { There are few opportunities to speak } \\
\text { with women on one to one basis }\end{array}$ & 1 & 2 & 3 & 4 \\
\hline
\end{tabular}




\begin{tabular}{|c|l|c|c|c|c|}
\hline d) & $\begin{array}{l}\text { I feel there is little I can do to help } \\
\text { them }\end{array}$ & 1 & 2 & 3 & 4 \\
\hline e) & $\begin{array}{l}\text { There are few resources in the } \\
\text { community where I could refer GBV } \\
\text { victims }\end{array}$ & 1 & 2 & 3 & 4 \\
\hline f) & $\begin{array}{l}\text { I could offend women if I ask them } \\
\text { directly about GBV }\end{array}$ & 1 & 2 & 3 & 4 \\
\hline g) & $\begin{array}{l}\text { Differences in culture beliefs and } \\
\text { values make it difficult to ask about } \\
\text { violence }\end{array}$ & 1 & 2 & 3 & 4 \\
\hline h) & $\begin{array}{l}\text { I need to focus my attention on other } \\
\text { health problems that have a higher } \\
\text { priority }\end{array}$ & 1 & 2 & 3 & 4 \\
\hline i) & $\begin{array}{l}\text { Getting involved in cases of violence } \\
\text { means that I have to participate in } \\
\text { police proceedings }\end{array}$ & 1 & 2 & 3 & 4 \\
\hline j) & $\begin{array}{l}\text { I could provoke retaliation from } \\
\text { abuser }\end{array}$ & 1 & 2 & 3 & 4 \\
\hline k) & $\begin{array}{l}\text { I have not received enough training } \\
\text { to address the issues of violence }\end{array}$ & 1 & 2 & 3 & 4 \\
\hline I) & $\begin{array}{l}\text { There is lack of law and regulations } \\
\text { that I could base on }\end{array}$ & 1 & 2 & 3 & 4 \\
\hline m) & \begin{tabular}{l} 
Others (specify)............................ \\
\hline
\end{tabular} & 1 & 2 & 3 & 4 \\
\hline
\end{tabular}

\section{C3. Is there any law in Viet Nam that addresses domestic violence?}
1. No
2. Yes
3. Do not know

If yes, can you list any law in Viet Nam that addresses domestic violence?

\section{C4. According to the law in Viet Nam, do health care providers have any legal obligation to treat victims of GBV?}
1. No
2. Yes
3. Do not know

If yes, what are legal obligations of the health care providers? 
C5. Do you think health care providers should routinely ask patients questions about possible GBV?
1. No
2. Yes
3. Do not know

If yes, why?

C6. Can you name at least two organizations that offer help or other services to women living in violent situations or having experienced GBV?

C7. In your clinic, is there a directory or written list of local organizations or other community resources to which you can refer women victims of GBV for further help?

1. No 2. Yes

If yes, have you ever used the directory/list?
3. Do not know

1. Yes

2. No

C8. To what extent, do you agree or disagree with the following statements about health care providers' responsibility to the GBV issues?

\section{Please circle one option between 1 to 5 for each row from a to e}

\begin{tabular}{|l|l|c|c|c|c|c|}
\hline & $\begin{array}{c}\text { Strongly } \\
\text { disagree }\end{array}$ & Disagree & $\begin{array}{c}\text { Neither } \\
\text { agree } \\
\text { nor } \\
\text { disagree }\end{array}$ & Agree & $\begin{array}{c}\text { Strongly } \\
\text { agree }\end{array}$ \\
\hline a) & $\begin{array}{l}\text { HCPs have responsibility to ask } \\
\text { about physical violence }\end{array}$ & 1 & 2 & 3 & 4 & 5 \\
\hline b) & $\begin{array}{l}\text { HCPs have responsibility to ask } \\
\text { about sexual violence }\end{array}$ & 1 & 2 & 3 & 4 & 5 \\
\hline c) & $\begin{array}{l}\text { HCPs have responsibility to ask } \\
\text { about psychological violence }\end{array}$ & 1 & 2 & 3 & 4 & 5 \\
\hline d) & $\begin{array}{l}\text { HCPs have responsibility to ask } \\
\text { about economic violence }\end{array}$ & 1 & 2 & 3 & 4 & 5 \\
\hline $\begin{array}{l}\text { HCPs have as much } \\
\text { responsibility to ask about } \\
\text { violence as they do to ask } \\
\text { about other causes of health } \\
\text { problems }\end{array}$ & 1 & 2 & 3 & 4 & 5 \\
\hline
\end{tabular}




\section{C9. Health providers can respond to victims of violence in many different ways. In the past years, how often did you do each of the following actions?}

\begin{tabular}{|c|l|c|c|c|c|}
\hline \multicolumn{5}{|c|}{ Please circle one option between 1 to 4} \\
\hline
\end{tabular}

\section{C10. How well trained/prepared do you feel to...}

\begin{tabular}{|c|l|c|c|c|}
\hline \multicolumn{5}{|c|}{ Please circle one option between 1 to 3 } \\
\hline \multicolumn{2}{|c|}{} & $\begin{array}{c}\text { Not adequately } \\
\text { trained or } \\
\text { prepared }\end{array}$ & $\begin{array}{c}\text { More or less } \\
\text { trained or } \\
\text { prepared }\end{array}$ & $\begin{array}{c}\text { Sufficiently } \\
\text { trained or } \\
\text { prepared }\end{array}$ \\
\hline a) & $\begin{array}{l}\text { Talk with women about gender } \\
\text { based violence }\end{array}$ & 1 & 2 & 3 \\
\hline b) & $\begin{array}{l}\text { Detect cases of physical } \\
\text { domestic violence }\end{array}$ & 1 & 2 & 3 \\
\hline c) & $\begin{array}{l}\text { Detect cases of psychological } \\
\text { violence }\end{array}$ & 1 & 2 & 3 \\
\hline
\end{tabular}




\begin{tabular}{|c|c|c|c|c|}
\hline d) & Detect cases of sexual violence & 1 & 2 & 3 \\
\hline e) & $\begin{array}{l}\text { Detect cases of economic } \\
\text { violence }\end{array}$ & 1 & 2 & 3 \\
\hline f) & $\begin{array}{l}\text { Identify clients with a history of } \\
\text { sexual abuse during childhood }\end{array}$ & 1 & 2 & 3 \\
\hline g) & $\begin{array}{l}\text { Provide care to victims of gender } \\
\text { based violence }\end{array}$ & 1 & 2 & 3 \\
\hline h) & $\begin{array}{l}\text { Assess the level of danger of a } \\
\text { woman living in a violent situation }\end{array}$ & 1 & 2 & 3 \\
\hline i) & Help client to create a safety plan & 1 & 2 & 3 \\
\hline j) & Document cases of violence & 1 & 2 & 3 \\
\hline k) & $\begin{array}{l}\text { Record details about a case of } \\
\text { violence in a clinical history form }\end{array}$ & 1 & 2 & 3 \\
\hline l) & $\begin{array}{l}\text { Provide information to affected } \\
\text { clients }\end{array}$ & 1 & 2 & 3 \\
\hline m) & $\begin{array}{l}\text { Provide referrals to victims of } \\
\text { gender based violence }\end{array}$ & 1 & 2 & 3 \\
\hline n) & $\begin{array}{l}\text { Counsel women about } \\
\text { emergency contraception }\end{array}$ & 1 & 2 & 3 \\
\hline o) & $\begin{array}{l}\text { Address the reproductive health } \\
\text { needs of women who have } \\
\text { suffered sexual violence }\end{array}$ & 1 & 2 & 3 \\
\hline
\end{tabular}

\section{C11. As a health care provider, in a scale from 1 to 5 , please indicate your knowledge about the following issues you may face when working with GBV victims.}

\section{Please circle one option for each items from $1-5$ \\ 1 = No knowledge at all, 5 = Very knowledgeable}

\begin{tabular}{|l|l|c|c|c|c|c|}
\hline a) & $\begin{array}{l}\text { Role of HCP in dealing with GBV } \\
\text { victims }\end{array}$ & 1 & 2 & 3 & 4 & 5 \\
\hline b) & $\begin{array}{l}\text { HCP responsibility required by Law } \\
\text { on Domestic Violence Prevention and } \\
\text { Control (2007) }\end{array}$ & 1 & 2 & 3 & 4 & 5 \\
\hline c) & Procedure to work with GBV victims & 1 & 2 & 3 & 4 & 5 \\
\hline d) & $\begin{array}{l}\text { Screening and response of HCPs to } \\
\text { GBV }\end{array}$ & 1 & 2 & 3 & 4 & 5 \\
\hline e) & GBV screening protocol & 1 & 2 & 3 & 4 & 5 \\
\hline f) & Management of GBV victims & 1 & 2 & 3 & 4 & 5 \\
\hline
\end{tabular}




\begin{tabular}{|c|l|c|c|c|c|c|}
\hline g) & Providing counseling for GBV victims & 1 & 2 & 3 & 4 & 5 \\
\hline h) & Dealing with perpetrator & 1 & 2 & 3 & 4 & 5 \\
\hline i) & $\begin{array}{l}\text { Required resources for health care } \\
\text { facility to provide treatment and } \\
\text { support for GBV victims }\end{array}$ & 1 & 2 & 3 & 4 & 5 \\
\hline j) & $\begin{array}{l}\text { Information about the setting up of } \\
\text { the counseling center to support GBV } \\
\text { women at health care facility }\end{array}$ & 1 & 2 & 3 & 4 & 5 \\
\hline
\end{tabular}

\section{TRAINING ON GBV}

D1. On which of the following topics related to GBV would you like to receive training? (Please circle options that you would like to receive)
a. Indicator of violence
b. How to ask questions to GBV victims
c. How to conduct a clinical exam
d. How to provide service to GBV victims
e. Referral options
f. Health effects
g. Legal issues
h. Others (specify)
i. None

\section{E. TRAINING MATERIAL}

\section{E1. In general, how would you rate the training materials?}

\begin{tabular}{|l|c|c|c|}
\hline \multicolumn{1}{|c|}{ Type of material } & Not useful & Useful & Very useful \\
\hline Printed documents & 1 & 2 & 3 \\
\hline Slide/handout & 1 & 2 & 3 \\
\hline $\begin{array}{l}\text { Case study and group } \\
\text { discussion }\end{array}$ & 1 & 2 & 3 \\
\hline
\end{tabular}


E2. Can you apply the knowledge and skills obtained from TOT to your work?
1. No
2. Yes
3. Unsure

E3. Do you feel comfortable to use knowledge and skills obtained from TOT to participate in GBV training as a facilitator?
1. No
2. Yes
3. Unsure

E4. Do you have any comments or recommendations to improve the future GBV training for HCPs? 




\section{$(P$ Population Council}

\section{Population Council Viet Nam}

41 Le Hong Phong, Ba Dinh Ha Noi, Viet Nam

Tel: (+84-4) 37345821

Fax : (+84-4) 37345827

Website: www.popcouncil.org 